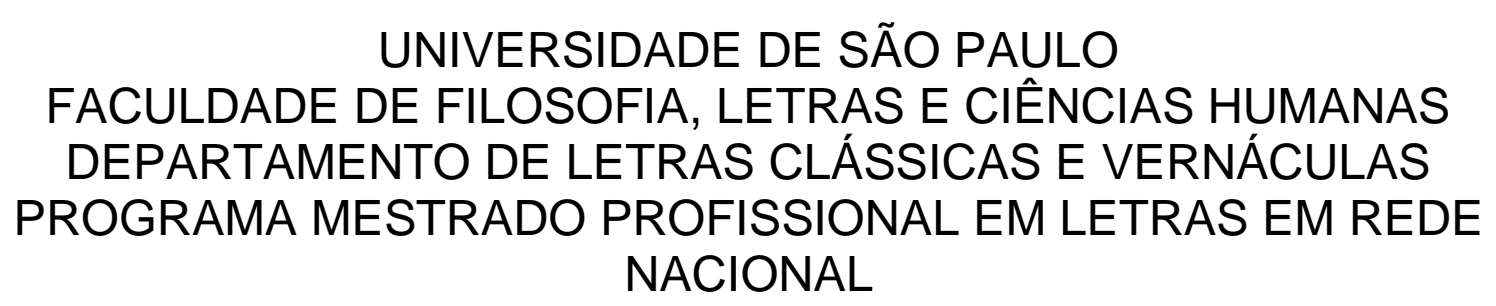

MARIA DE FÁTIMA RODRIGUES DA SILVA PAULINO

\title{
Argumentação e cidadania no artigo de opinião em sala de aula
}

( Versão corrigida ) 
UNIVERSIDADE DE SÃO PAULO

FACULDADE DE FILOSOFIA, LETRAS E CIÊNCIAS HUMANAS DEPARTAMENTO DE LETRAS CLÁSSICAS E VERNÁCULAS PROGRAMA MESTRADO PROFISSIONAL EM LETRAS EM REDE NACIONAL

\section{Argumentação e cidadania no artigo de opinião em sala de aula}

(versão corrigida)

Maria De Fátima Rodrigues da Silva Paulino

Dissertação apresentada ao Programa de Mestrado Profissional em Letras em Rede Nacional do Departamento de Letras Clássicas e Vernáculas da Faculdade de Filosofia, Letras e Ciências Humanas da Universidade de São Paulo, para a obtenção do título de Mestre em Letras.

Orientadora: Profa. Dra. Sheila Vieira de Camargo Grillo

São Paulo

2015 
Autorizo a reprodução e a divulgação total ou parcial deste trabalho, por qualquer meio convencional ou eletrônico, para fins de estudo e pesquisa, desde que citada a fonte. 
Nome: Maria de Fátima Rodrigues da Silva Paulino.

Título: Argumentação e cidadania no artigo de opinião em sala de aula

Dissertação apresentada ao Programa de Mestrado

Profissional em Letras em Rede Nacional do

Departamento de Letras Clássicas e Vernáculas da

Faculdade de Filosofia, Letras e Ciências Humanas da

Universidade de São Paulo, para a obtenção do título de Mestre em Letras.

Aprovada em

\section{BANCA EXAMINADORA}

Profa.Dra.:

Instituição:

Julgamento:

Assinatura:

Prof. Dr. : Instituição:

Julgamento:

Assinatura:

Profa.Dra.: Instituição:

Julgamento: Assinatura: 
À minha família.

Ao meu eterno mestre Prof. Antônio Vicente da Silva Bueno. 


\section{AGRADECIMENTOS}

À Professora Dra. Sheila Vieira de Camargo Grillo, pelo apoio, confiança, paciência e generosidade na orientação deste trabalho, meu sincero reconhecimento.

À Professora Mariângela de Araújo e ao Professor Dr. Álvaro Caretta pelas valiosas contribuições dadas na qualificação

À Universidade de São Paulo e aos professores do Programa Mestrado em Letras em Rede Nacional - PROFLETRAS, cujos ensinamentos enriqueceram não só meus conhecimentos, mas contribuíram com minha prática.

À minha família, pela compreensão de minhas ausências e negativas em vários momentos, pelo apoio e incentivo incondicionais.

Aos amigos que me incentivaram e acreditaram em meu potencial.

A Deus, por ter me concedido o dom da vida e a graça de conviver e aprender a cada dia com todas essas pessoas que fazem parte de minha caminhada.

À CAPES, pelo apoio financeiro concedido a esta pesquisa. 
...o enunciado é um elo na cadeia da comunicação discursiva e não pode ser separado dos elos precedentes que 0 determinam tanto de fora quanto de dentro, gerando nele atitudes responsivas diretas $e$ ressonâncias dialógicas.

Bakthin 


\section{RESUMO}

\section{PAULINO, Maria de Fátima Rodrigues da Silva Paulino Argumentação e cidadania}

no artigo de opinião em sala de aula. 164 f. Dissertação (Mestrado). Faculdade de Filosofia, Letras e Ciências Humanas, Universidade de São Paulo, São Paulo/SP.

A presente pesquisa tem como objetivo investigar as atividades do professor com gêneros argumentativos em sala de aula e analisar em que medida a preparação dessas atividades contribuem com a escrita do gênero artigo de opinião por alunos do 9ำ ano do Ensino Fundamental de uma escola pública do Estado de São Paulo. Seguindo os preceitos dos PCNs e do Currículo do Estado de São Paulo, adotou-se a língua como objeto de estudo da disciplina de Língua Portuguesa, assim como as concepções de gêneros discursivos apoiadas em Bakthin (2003), Marcuschi (2008) e Rojo (2000). Em relação à organização do trabalho pedagógico, apoiados nas orientações de Schneuwly e Dolz (2004) planejou-se uma sequência didática para a produção de artigo de opinião. Tomou-se como produção inicial e produção final as avaliações externas aplicadas, respectivamente, no primeiro e segundo semestre, as AAP (Avaliação de Aprendizagem em processo). As atividades dos materiais didático-pedagógicos utilizados foram selecionadas procurando atender a reflexão sobre as características do gênero formuladas por Rodrigues (2000) Brakling (2000) e outros autores pesquisados. Quanto às estratégias de ensino de produção textual escrita, recorremos a Antunes (2003) e Geraldi (1991), evidenciando as etapas de planejamento e preparo para a produção escrita. A análise das produções, dentro de uma perspectiva enunciativa e interacionista da língua, procurou evidenciar os recursos linguísticos-discursivo empregados pelos alunos para a construção da argumentação. Para melhor compreender o uso desses recursos argumentativos recorreu-se à Retórica de Aristóteles associando-se aos estudos da Nova Retórica de PERELMAN \& OLBRECHTS-TYTECA (1996). Os resultados da pesquisa demonstram que há uma relação direta entre as escolhas teóricas para a organização do trabalho pedagógico e a melhora da qualidade de escrita dos alunos. Confirmou-se também a hipótese da relevância do ensino dos gêneros argumentativos, pois os alunos-autores demonstraram um posicionamento crítico em relação aos temas abordados nas produções textuais. Houve ganhos quanto à organização e produtividade textual, efeito das atividades de leitura e alimentação temática, mas por outro lado, as fragilidades das atividades específicas para a construção do gênero, aliados aos problemas relativos às propostas sugeridas apontam para uma reorientação do trabalho com o gênero artigo de opinião.

Palavras-chave: produção escrita, argumentação, artigo de opinião. 


\section{ABSTRACT}

PAULINO, Maria de Fátima Rodrigues da Silva. Argumentation and citizenship in opinion articles in the classroom. $163 \mathrm{f}$. Master's dissertation. Faculty of Philosophy, Letters and Human Sciences, University of São Paulo, São Paulo/SP.

This research aims to investigate teacher-proposed classroom activities involving argumentative genres and analyze the extent up to which the preparation of those activities contribute to the writing of opinion articles of $9^{\text {th }}$-graders of a public school run by São Paulo state. Based on the National Curriculum Parameters and on the Curriculum of the State of São Paulo, language was embraced as the study object of the discipline Portuguese, along with the conceptions of discourse genres by Bakhtin (2003), Marcuschi (2008), and Rojo (2000). Regarding the organization of the pedagogical work, a didactic sequence based on Schneuwly and Dolz's (2004) guidelines was planned aiming at the writing of an opinion article. The external Evaluations of Learning in Process in the first and in the second semesters were taken respectively as initial and final production. The activities in the didacticpedagogical materials were selected when in keeping with the reflections on the characteristics of the genre opinion article proposed by Rodrigues (2000), Brakling (2000), among others. As to the teaching strategies of written production, the research resorted to the works of Antunes (2003) and Geraldi (1991), making evident the planning and preparation stages of the written production. The analysis of the productions, from an enunciative and interactional perspective of language, sought to reveal the linguistic-discursive strategies used by students in the construction of argumentation. In order to better understand the use of those strategies, Aristotle's Rhetoric was resorted to, as well as the New Rhetoric, by Perelman and OlbrechtsTyteca (1996). The results of the research suggest that there is a direct relation between the theoretical choices for the organization of the pedagogical work and the improvement observed in student writing. The teaching of argumentative genres proved relevant, as student-authors were able to take a critical stand towards the topics of the written assignments. Improvements were observed regarding text organization and productivity - an effect of the reading and topic-related activities; on the other hand, the weak points of the specific activities for genre construction, alongside the problems related to the suggested plans, point to the reorientation of the work with opinion articles.

Keywords: written production, argumentation, opinion article. 


\section{LISTA DE QUADROS}

Quadro 1: Transcrição do Sumário -Caderno do Professor- 9ª ano- Vol 1

Quando 2: Estrutura para a argumentação formal

Quadro 3: IDESP 2011- Boletim da Escola

Quadro 4: IDESP 2011 - Resultado da Rede Estadual

Quadro 5: $\quad$ IDESP 2012 - Boletim da Escola

Quadro 6: IDESP 2012 -Resultado da Rede Estadual

Quadro 7: IDESP 2013 - Boletim da Escola

Quadro 8: IDESP 2013 - Resultado da Rede Estadual

Quadro 9: Conceitos adotados pelo Currículo do Estado de São Paulo

Quadro 10: AAP - Produção Textual. 9ำ ano- 1ํㅗㄹ semestre 2014

Quadro 11: Transcrição de atividade livro didático- Nas linhas do texto p.158

Quadro 12: Transcrição de atividade livro didático- Nas entrelinhas do textop.158

Quadro 13: Quadro de articuladores textuais- livro didático

Quadro 14: Transcrição atividade do caderno do aluno-p. 16

Quadro 15: Quadro síntese- caderno do aluno-p20 


\section{LISTA DE FIGURAS}

Figura 1: Esquema da Sequência Didática- Dolz e Schneuwly:

Figura 2: Proposta de produção textual - AAP- $9^{\circ}$ ano, $1^{\circ}{ }^{\circ}$ semestre 2014.p.1

Figura 3: Proposta de produção textual - AAP- 9ano, $1^{\circ}$ - semestre 2014.p.2

Figura 4: $\quad$ Proposta de produção textual - AAP-9aa, $1^{\circ}$ semestre 2014.p.3

Figura 5: $\quad$ Proposta de produção textual - AAP-9ํano, $1^{\circ}$ semestre 2014.p.4

Figura 6: Sumário do livro didático- Unidade 5

Figura 7: Quadro 1 -apresentação dos gêneros textuais Dolz e Schneuwly

Figura 8: Atividade do livro didático- p. 159

Figura 9: $\quad$ Atividade do livro didático- p 161

Figura 10: Charge Laerte- caderno do aluno

Figura 11: Proposta de produção textual- AAP 9 $^{\circ}$ ano $2^{\circ}$ semestre. p.1

Figura 12: Proposta de produção textual- AAP $-9^{\circ} a n o 2^{\circ}$ semestre. p. 2

Figura 13: Proposta de produção textual- AAP -9aa $2^{\circ}$ semestre. p.3

\section{LISTA DE TABELAS}

Tabela 1- Ocupação profissional dos membros das famílias

Tabela 2- Escolaridade dos responsáveis

Tabela 3- Número de membros que residem com o aluno 


\section{LISTA DE ABREVIATURAS E SIGLAS}

AAP: $\quad$ Avaliação da Aprendizagem em Processo

PCNs: $\quad$ Parâmetros Curriculares Nacionais

SD: $\quad$ Sequência didática

SARESP: $\quad$ Sistema de Avaliação de Rendimento Escolar do Estado de São Paulo 


\section{Sumário}

INTRODUÇÃO

\section{CAPÍTULO 1}

CONTEXTO TEÓRICO DA PRÁTICA DE PRODUÇÃO TEXTUAL ..........................19

1.1 PESQUISAS SOBRE PRODUÇÃO DE TEXTOS NA ESCOLA ……........................ 19

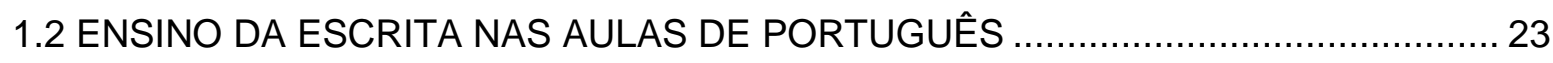

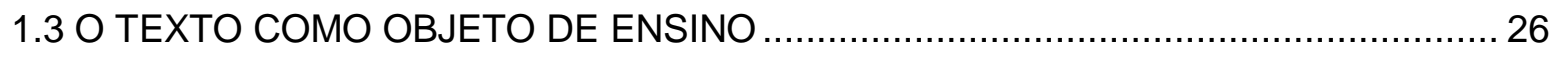

1.3.1 OS GÊNEROS DO DISCURSO COMO OBJETO DE ENSINO …....................... 28

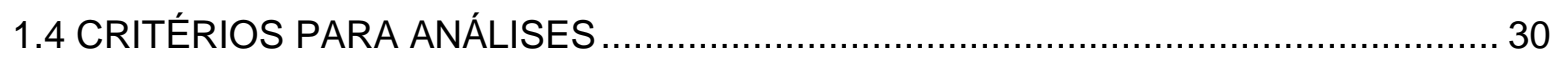

1.4.1 ASPECTOS ARGUMENTATIVOS DA LINGUAGEM ......................................... 31

\section{CAPÍTULO 2}

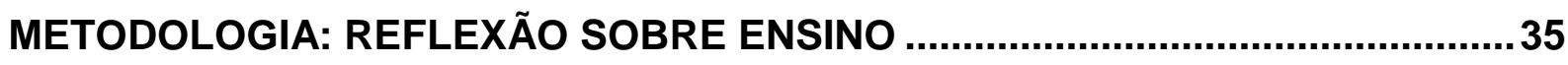

2.1 POR QUE OS GÊNEROS ARGUMENTATIVOS NA ESCOLA? ................................ 35

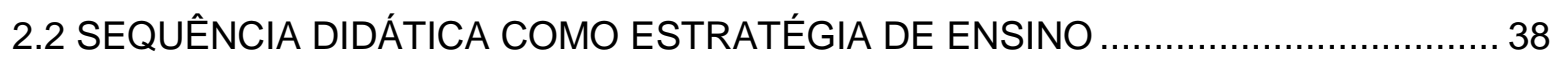

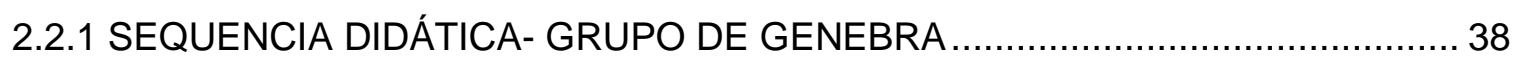

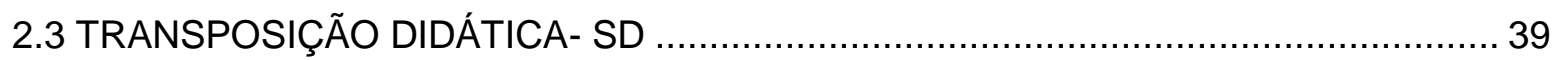

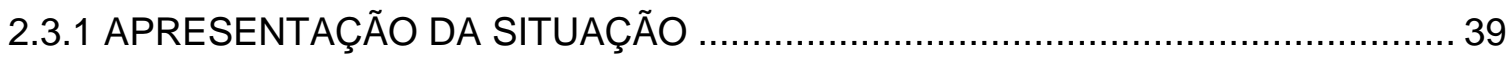

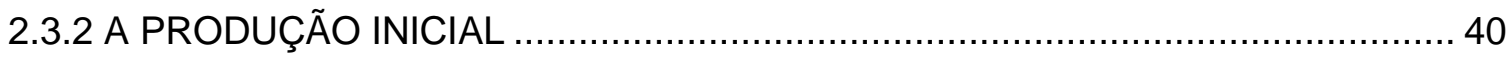

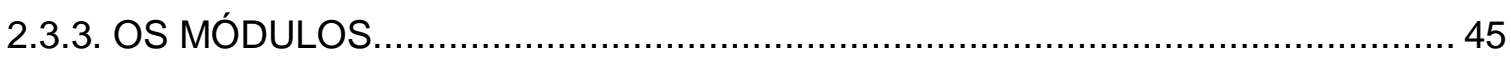

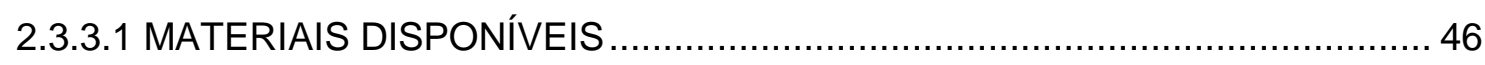

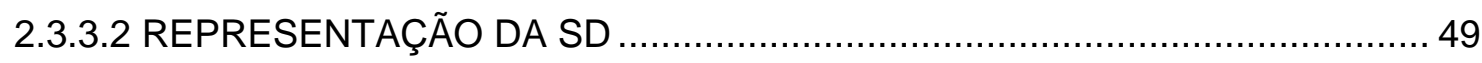

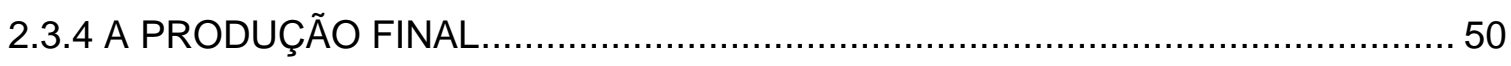

2.4 JUSTIFICATIVA DA METODOLOGIA ESCOLHIDA ............................................... 51

2.5 CONSIDERAÇÕES SOBRE GÊNEROS ARGUMENTATIVOS- O ARTIGO DE

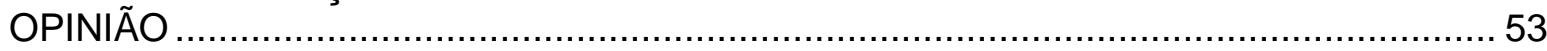

\section{CAPÍTULO 3}

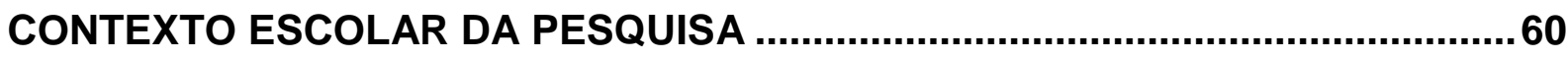

3.1 CONSIDERAÇÕES SOBRE O CURRÍCULO DO ESTADO DE SÃO PAULO .............6 65

\section{CAPÍTULO 4}

DESCRIÇÃO, JUSTIFICAÇÃO E ANÁLISE DO TRABALHO COM AS CARTAS DE

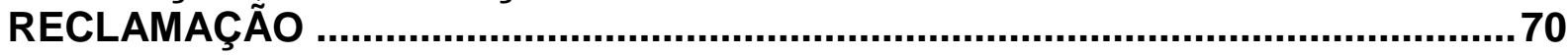

4.1 RESULTADOS DA AAP (AVALIAÇÃO DA APRENDIZAGEM EM PROCESSO)-1 aㅡ $^{2}$

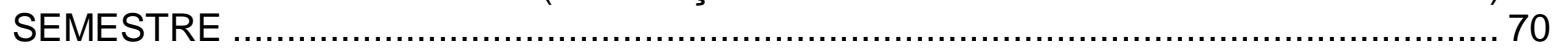

4.2 TRABALHANDO COM CARTAS ARGUMENTATIVAS: UMA APROXIMAÇÃO DO GÊNERO (MÓDULO 1 DA SD).... 
4.2.2 DESCRIÇÃO DA METODOLOGIA DE SALA DE AULA PARA SEQUÊNCIA DA CARTA

\section{CAPÍTULO 5}

O ARTIGO DE OPINIÃO: DESENVOLVIMENTO DOS MÓDULOS DA SD-

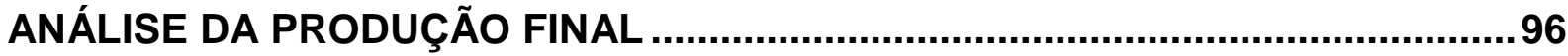

5.1 DESCRIÇÃO DO MÓDULO 2: ANALISANDO UM ARTIGO DE OPINIÃO ………...... 97

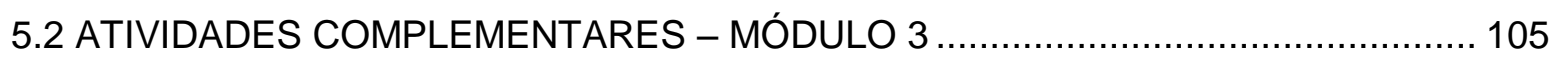

5.3 LEITURA DE GÊNEROS ARGUMENTATIVOS -DESCRIÇÃO DO MÓDULO 4 ...... 111

5.3.1 LEITURA E ANÁLISE DE TEXTOS ARGUMENTATIVOS …............................ 112

5.4 ATIVIDADE COM ARTIGO DE OPINIÃO - DESCRIÇÃO DO MÓDULO $5 \ldots \ldots \ldots \ldots . . . .114$

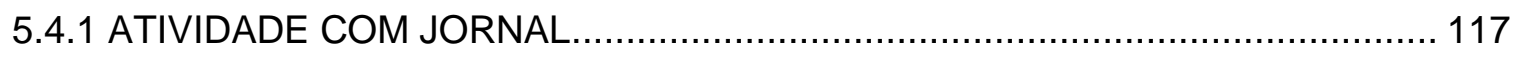

5.5 DESCRIÇÃO E ANÁLISE DE PRODUÇÃO TEXTUAL - AVALIAÇÃO BIMESTRAL 117 5.6 DESCRIÇÃO E ANÁLISE DA AAP - 2º SEMESTRE- PRODUÇÃO FINAL DA SD .. 127

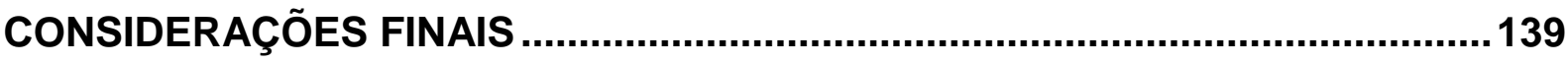

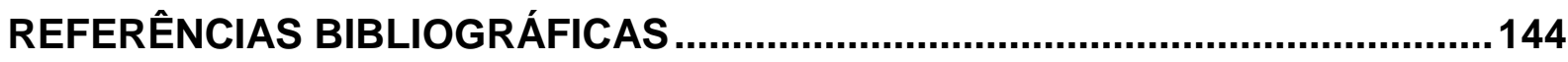

ANEXOS

ANEXO A QUESTIONÁRIO SOCIOECONÔMICO .........................................151

ANEXO B TEXTOS DOS ALUNOS - AVALIAÇÃO BIMESTRAL.....................153

ANEXO C TEXTOS DOS ALUNOS - AAP - 2ㅇ SEMESTRE ….....................157

ANEXO D ATIVIDADES DE PONTUAÇÃO …............................................161 


\section{INTRODUÇÃO}

A competência argumentativa integra as mais variadas atividades discursivas dos sujeitos falantes. Desde a antiguidade, os gregos se deram conta de que a capacidade de argumentar em situações públicas da cidade era fundamental para o exercício da democracia. Em sua "Retórica", Aristóteles elaborou um dos mais influentes trabalhos sobre a "arte" de persuadir, no qual considerava o gênero deliberativo mais importante do que o epidítico e o judiciário, porque incidia sobre questões relativas à vida da coletividade. A disciplina consistia, ao mesmo tempo, em uma teoria e uma prática pedagógica sobre a arte de persuadir.

A retórica é uma influência primeira em nosso trabalho por diversos motivos. Primeiro, dentre as diversas habilidades e conhecimentos envolvidos no processo de aquisição da escrita (a relação fonema/grafema, as estruturas sintáticas específicas da escrita, o sistema de pontuação, o domínio das variantes escritas etc.), selecionamos a capacidade de argumentação, em gêneros escritos, como nosso objeto de investigação, por considerá-la de fundamental importância tanto para o exercício da cidadania, quanto para a ampliação e fundamentação da visão de mundo dos estudantes. É por meio da construção de argumentos persuasivos que o estudante poderá agir de modo eficaz nas mais variadas situações sociais, a fim de fazer valer seus direitos e se fazer ouvir e respeitar pelos demais.

Em segundo lugar, o currículo do $9^{\circ}$. ano do Estado de São Paulo privilegia as habilidades e competências linguísticas relacionadas aos gêneros argumentativos, trazendo nos materiais de apoio do professor e do aluno atividades que conduzem à reflexão e à aquisição de gêneros argumentativos tais como: artigo de opinião, carta do leitor, resenha crítica, comentários opinativos sobre textos lidos etc. Considerando que esse material orienta o trabalho escolar em língua portuguesa de toda a rede pública do Estado de São Paulo, julgamos que a investigação das atividades do professor com gêneros argumentativos em sala de aula e os resultados desse trabalho na produção escrita dos alunos poderão contribuir de modo significativo para o aprimoramento das práticas didáticas de trabalho com textos argumentativos na escola. 
Por fim, dentre os gêneros propostos nesse material didático, selecionamos o artigo de opinião como objeto de pesquisa, uma vez que ele permite aos estudantes o desenvolvimento de suas habilidades argumentativas com o propósito de interferir em questões relacionadas à vida da coletividade, assim como teorizou Aristóteles a respeito do gênero deliberativo. Cabe ainda salientar que a prova de redação do final do ciclo dois do ensino fundamental, a prova SARESP (Sistema de avaliação do rendimento escolar do Estado de São Paulo) propõe a produção de um artigo de opinião, como instrumento de avaliação das habilidades de escrita dos estudantes.

Em nossa prática docente na escola pública, sempre nos sentimos desafiados a motivar os estudantes a se expressarem, por escrito, de modo competente, em diversas situações sociais e, sobretudo, naquelas que exigem um domínio de habilidades argumentativas com finalidade prática, isto é, dirigirem-se por escrito à direção da escola com vistas a solicitar melhorias ou mesmo autorização para atividades extraclasse; encaminharem pedidos escritos de melhorias ao bairro ou à cidade dirigidos aos órgãos competentes; elaborarem reclamações sobre serviços públicos e privados etc.

O texto é tomado, nesta pesquisa, como objeto de ensino na disciplina de língua portuguesa, sendo ele constituído pela interação da linguagem. Os princípios da teoria bakthinina, na qual os enunciados emergem do contato social nos processos comunicativos reforçaram nossa hipótese, pois quanto maior forem as experiências com outros textos, melhor será a produção do aluno.

Buscamos fundamentar nossa prática em Antunes (2003) e Geraldi (1991), autores que trouxeram grande colaboração para o planejamento das atividades. Os estudos de Schneuwly e Dolz (2004), sobre as sequências didáticas, direcionaram o plano global deste trabalho. Perelman \& Olbrechts-Tyteca (1996) colaboraram com a análise da argumentação presente nos textos dos alunos.

Em síntese, nosso trabalho tem por finalidade a análise de uma prática de sala de aula do $9^{\circ}$. ano do ensino fundamental que visa ao ensino-aprendizagem do gênero argumentativo, artigo de opinião. Para atingirmos esse objetivo, o trabalho está organizado nas seções elencadas abaixo.

O primeiro capítulo, apresenta uma revisão teórica de trabalhos realizados na área de ensino da escrita; alguns fundamentos teóricos sobre conceito de gêneros textuais/discursivos e sua relação com a prática da disciplina de língua portuguesa; reflexões sobre o processo de argumentação na escrita. 
O segundo capitulo, faz uma exposição da metodologia adotada, com a apresentação do conceito de sequência didática e das sequências de trabalho com os gêneros artigo de opinião e carta de reclamação; apresentação dos fundamentos teóricos sobre os gêneros argumentativos trabalhados.

O terceiro capítulo, descreve e caracteriza o contexto escolar e sócioeconômico-cultural dos estudantes envolvidos na pesquisa; uma breve análise do currículo de língua portuguesa do ensino fundamental do Estado de São Paulo, privilegiando o $9^{\circ}$. ano;

O quarto capítulo, inicia a descrição do trabalho em sala de aula, começando pela análise das primeiras produções dos alunos e justificando a necessidade de apresentação de uma sequência didática para escrita do gênero carta de reclamação, como atividade introdutória para o desenvolvimento da argumentação e da cidadania.

O quinto capítulo compreende duas partes: a primeira, faz a descrição dos módulos da sequência didática, ou seja, as atividades de preparação para a escrita do artigo de opinião; a segunda parte, faz a análise da produção final.

Por fim, teceremos nossas considerações finais procurando relacionar os resultados e a relevância desse trabalho para a prática do ensino de língua na sala de aula. 


\section{CAPÍTULO 1 \\ CONTEXTO TEÓRICO DA PRÁTICA DE PRODUÇÃO TEXTUAL}

Neste capítulo, traremos o resultado da abordagem teórica de produção textual, por meio de sínteses de pesquisas de trabalhos anteriores que nos direcionaram a uma investigação mais adequada à nossa situação estudada. Em seguida, exporemos os princípios teóricos que subsidiam o trabalho com a escrita de alunos.

\subsection{PESQUISAS SOBRE A PRODUÇÃO DE TEXTOS NA ESCOLA}

Estudos na área de produção de textos apontam diversas abordagens em relação à análise tanto da qualidade da escrita quanto das diversas dificuldades que essa modalidade da língua representa no universo do aluno. Após um levantamento em bancos de dissertações e teses de universidades paulistas, selecionamos quatro trabalhos que contribuíram na realização dessa pesquisa, em razão da diversidade de abordagens e da pertinência temática.

Brito (2011), em sua pesquisa, analisa textos produzidos para o vestibular de 2007 da USP. O autor procura responder à questão: como a interação entre leitura e escrita influenciam o evento do letramento? A partir da premissa de que há uma crise na linguagem, discorre sobre os aspectos a-históricos, apoiado em Tfouni (1994) e Rocco (1981), cujas teorias convergem para entender como os problemas da linguagem afetam a escrita de textos dos vestibulandos. Os aspectos históricos pontuam a heterogeneidade da escrita como marco determinante para o processo de produção escrita.

Em Duarte (1998), há o conceito de que o texto é uma atividade que vai além da subjetividade, pois é caracterizado por marcas discursivas originadas na leitura de outros textos ou situações sociais.

Suas hipóteses referem-se à leitura e escrita (em interação) como elementos integrantes de cada momento do nosso cotidiano, o que torna o texto um acontecimento discursivo. Explicita, também, que essa interação seja o caminho 
para apreender e melhor compreender eventos de letramento, pois muitos desses eventos são processos dessa interação.

Traça como objetivo central abordar a realidade "viva" da redação, no Concurso Vestibular, analisando a interação que há entre leitura e produção textual. Seus objetivos específicos são: i) compreender o funcionamento sociodiscursivo do gênero do discurso no qual a interação leitura/escrita está ancorada; ii) investigar a heterogeneidade que liga de maneira constitutiva o Mesmo do discurso com seu outro.

O autor chega às seguintes conclusões: a atualidade do acontecimento da leitura é engendrada pelas condições imediatas da produção (na interação escrevente/corretor) já a memória desse acontecimento é engendrada pelas condições amplas de produção.(Brito, 2011, p.189)

Percebemos, com isso, que ao se pedir uma produção textual para o aluno, em um momento pontual, ele recorrerá aos recursos disponíveis nos textos de apoio, com a preocupação de atender às expectativas do corretor. Entretanto, se a produção seguir uma sequência que oportunize a pesquisa e o resgate de outros conhecimentos, amplifica-se a qualidade textual.

Pimentel (1998), também analisa a questão da produção textual de alunos, embora em contextos diferentes, com o objetivo de avaliar os modos de relação que os textos dos alunos estabelecem com suas experiências com a linguagem, no momento específico da produção de texto; a autora se apoia em outros autores como Attayde Junior (1995), Geraldi (1984,1991), Pécora (1983) e De Lemos (1977), cujas concepções sobre produção textual convergem no sentido de considerar marcas de artificialidade, descontextualização discursiva e falta de domínio das convenções da escrita.

A autora elenca alguns problemas a serem analisados nas produções escritas de alunos da $7^{\text {a }}$ série de uma escola pública de Campinas, tais como: i) como a interdiscursividade e a intertextualidade são articuladas na produção escrita; ii) que relações são estabelecidas com os gêneros narrativos literários e com outros gêneros que fizeram parte das experiências dos sujeitos pesquisados.

Tendo como hipótese que as experiências com a linguagem são reconstruídas nos textos pela relação de informações, temas, estruturas e recursos linguísticos, a autora busca uma abordagem teórica apoiada, principalmente em Bakhtin. Em sua busca, comprova que a teoria bakhtiniana de interação e da 
enunciação da linguagem se aplica à sua hipótese, pois, segundo a concepção desse autor, o sujeito não possui uma linguagem pronta, mas vai construindo-a à medida que interage verbalmente com outros sujeitos. Outro autor que reforça essa abordagem é Geraldi ao afirmar que a linguagem, mesmo a do sujeito, não é algo isolado, é "...um trabalho social e histórico seu e dos outros e para os outros e com os outros que ela se constitui" (Geraldi, 1996 apud Pimentel, 1998, p.12)

A abordagem da intertextualidade e interdiscursividade é comprovada com a investigação dos livros didáticos, nos quais aparecem alguns recursos verbais e não verbais de outros textos e discursos manipulados pelos alunos dentro e fora da escola, assim como marcas de textos midiáticos, não pertencentes à tradição letrada culta.

A produção e revisão de texto também são objeto de pesquisa de Schiavoni (2009), que objetiva verificar os efeitos das intervenções educativas, baseadas em estratégias de planejamento de produção e revisão de textos. Além de avaliar a ocorrência de modificações, após a aplicação das estratégias de intervenção.

Utilizou-se, para sua pesquisa, produções de textos narrativos de 28 estudantes do $9^{\circ}$ ano do Ensino Fundamental, distribuídos em dois grupos, a saber: 14 no grupo experimental e 14 no grupo de controle. Por meio de um pré-teste e um pós teste, com quatro sessões de intervenções, aplicou um protocolo de investigação de estratégias utilizadas para as produções do grupo experimental.

Para fundamentar sua pesquisa, apoiou-se em teorias cognitivistas; essas sustentam que a produção do texto escrito acontece em um processo de aprendizagem que requer estratégias de composição e possui etapas específicas, conforme afirmam os autores. A pesquisadora faz um histórico das concepções de estudo sobre produção textual, passando por Emig (1971), Bereiter e Scardamalia e acentua sua análise em Hayes e Flower, que, em síntese, propõem as seguintes etapas para a produção: natureza da tarefa; a memória a longo prazo do escritor e os processos de escrita. Compreende nesse processo o planejamento, a tradução e a revisão. A tradução é entendida pelos autores como um processo que consiste na transformação das ideias coletadas durante o planejamento em sentenças próprias da língua. Segundo Schiavoni (2009), os estudantes podem se beneficiar com as intervenções e utilização de estratégias para a produção de textos. Para isso, é preciso que compreendam que a revisão faz parte do processo de produção, assim como o planejamento dos seus textos. 
Cabe ao educador o ensino de atividades de revisão não como conteúdo específico, mas como a construção de habilidades de escrita. Além disso, é preciso mostrar ao aprendiz que o seu projeto de texto é um rascunho que pode e deve ser modificado até se alcançar o objetivo pretendido. Para isso, o professor deve usar estratégias que funcionem como roteiros para que o aluno perceba seu percurso, pois, segundo a autora, essa é uma das grandes dificuldades dos alunos: compreender onde errou e como chegar ao produto final.

O processo de revisão e interação do professor com aluno foi objeto de pesquisa no trabalho de Grillo (1995). Com o objetivo de desenvolver, no aluno, a visão da escrita enquanto trabalho, da qual a revisão faz parte integrante do processo de escrita, a professora/pesquisadora, em uma abordagem sociointeracionista, coletou textos desenvolvidos durante um semestre em uma sala de $7^{\mathrm{a}}$ série do ensino supletivo.

Sua pesquisa aponta para a orientação do professor e como esta molda a reescrita do texto por seu autor. Em sua análise, as produções foram distribuídas em três grupos, conforme a habilidade de escrita dos alunos. O que se percebe é que, como aponta a autora, o desenvolvimento da escrita depende de dois grandes fatores: tanto da habilidade do corretor (professor), quanto da habilidade do aluno em encontrar as soluções para a revisão do texto. Por isso, a interação deve levar em conta vários aspectos em relação à produção dos alunos. A autora verificou que problemas de coerência textual não foram encontrados nos textos da maioria dos alunos, mas sim de coesão e estruturação textual. Em muitos casos, as intervenções da professora foram suficientes para levar os alunos a reformularem adequadamente seus textos. $\mathrm{O}$ que a autora, no papel de pesquisadora, percebe é que são insuficientes ou inadequadas as propostas de revisão para determinadas situações, além de considerar as experiências com a escrita um dos fatores que dificultam a melhoria na qualidade de produção de texto dos alunos.

Pesquisas como as descritas acima vêm colaborar para ampliar a visão que se tem sobre a importância de trabalhar o processo de apropriação da linguagem escrita pelos alunos; quais intervenções poderão ser aplicadas com maior sucesso e orientar para o planejamento de atividades de revisão mais eficientes.

Como foi visto no trabalho de Pimentel (1998), procuraremos, por um lado, analisar como outras vozes aparecem nos textos por meio da leitura em sala de aula, e por outro, como a relação da leitura influencia na apropriação da escrita, 
pois, como foi visto no trabalho de Grillo (1995), sua ausência se manifesta no não entendimento das propostas de revisão.

\subsection{ENSINO DA ESCRITA NAS AULAS DE PORTUGUÊS}

As dificuldades de produzir textos escritos, conforme levantado por Antunes (2003), provêm de vários fatores. Principalmente do hábito da escola priorizar exercícios mecânicos com a linguagem desde o início da aprendizagem, como por exemplo, a construção de frases isoladas, descontextualizada de uma situação real de comunicação. Segundo a autora,

[...]Parece incrivel, mas é na escola que as pessoas 'exercitam' a linguagem ao contrário, ou seja, a linguagem que não diz nada [...] o aluno produz uma escrita improvisada, sem planejamento e sem revisão, na qual o que conta é, prioritariamente, a tarefa de realizá-la, não importa 'o que se diga' e o 'como se faz'. (ANTUNES, 2003.p.27,grifo da autora)

Esse aspecto nos lembra o que Bakthin (2003) afirma em seu ensaio "Os gêneros do discurso", quando aponta que não aprendemos a língua materna por meio de dicionários e gramáticas, nem mesmo estudando sua estrutura, mas sim em contato com enunciados reais, concretos. O mesmo vale para a escrita: como aprender a se comunicar, por escrito, elaborando frases e construções que não utilizamos em outras situações, senão na escola?

Antunes (2003) também postula que a atividade de escrita é interativa quando se produz um texto considerando as ideias do outro, o contexto de produção e de recepção. Nesse aspecto, a escrita pode ser tão dialógica e dinâmica quanto a fala, pois o enunciador interage com seus possíveis interlocutores e pode fazer reformulações de acordo com o que acredita ser mais adequado e eficiente. Quando o autor prevê a recepção do seu texto em dada esfera da comunicação, pode fazer escolhas mais adequadas para a sua escrita. Esse processo de interação só é possível quando as situações escolares permitem que o aluno vivencie a experiência de: i) primeiro planejar; ii) depois, escrever - o que seria a primeira versão de seu texto e iii) e, em seguida, revisar e reformular seu texto, conforme cada caso, para deixá-lo na versão definitiva. Como vimos em seu trabalho, SCHIAVONI (2009) 
também aponta para uma prática que conscientize o estudante a produzir várias versões do seu texto, reconhecendo assim, que o domínio da escrita é um processo a ser desenvolvido.

Antes de colocar em prática a atividade, Geraldi (1991) explicita que são necessárias algumas condições necessárias à produção de um texto, afirmando que:

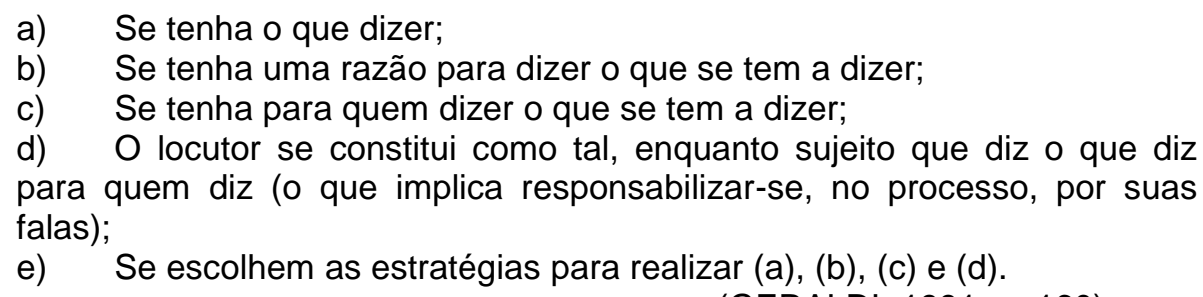

(GERALDI ,1991, p. 160)

Essas condições estão relacionadas à etapa de planejamento referida por Antunes (2003) e retomadas pela autora quando afirma em uma visão interacionista, a escrita é o resultado da seleção de informações que alguém fez para direcionar a um outro alguém. Quando o enunciador se manifesta verbalmente, pretende partilhar suas ideias, crenças e sentimentos com o destinatário. Para que haja um compartilhamento, a autora comunga com Geraldi (1991) que "Ter o que dizer é, portanto, uma condição prévia para o êxito da atividade de escrever. " (ANTUNES, 2003.p.45) (grifo da autora). Para a autora somente o conhecimento linguístico (lexical ou gramatical) não é suficiente para se produzir textos. As ideias e informações proporcionam o uso das palavras. Daí a importância de se ampliar o repertório, antes de solicitar uma produção de texto, pois com a prática de leitura não se aprende apenas a analisar gramaticalmente a língua, mas percebê-la no uso interativo em diversos gêneros.

Um outro aspecto que também precisa ser considerado é a importância do outro no processo de escrita, pois isso é fundamental para que se façam as adequações linguístico-discursivas. Escrever um texto sem ter um leitor em mente, ou, o que acontece, muitas vezes, ter um leitor hipotético, dificulta as escolhas do enunciador. Este não tem como saber se o outro comunga com suas ideias, ou se foi preciso, claro o suficiente para alcançar o objetivo do texto. Ter um auditório indistinto ou universal, do qual não se pode adivinhar uma resposta, retira o caráter 
interacionista da escrita, tornando, assim, o texto uma relação de sinais desprovido de linguagem (ANTUNES, 2003).

As atividades de escrita propostas como avaliações externas e/ou internas não permitem que o aluno cumpra os procedimentos apontados até aqui. Quando ao estudante é solicitado um texto em situação de avaliação, a princípio, ele elege como seu interlocutor, o professor-corretor. Sabe de antemão que os interlocutores sugeridos nas propostas não são reais. O assunto quase sempre é uma surpresa, implicando o pressuposto que o estudante já tenha conhecimentos prévios e/ou seja um leitor habitual. Nesse contexto, emprega estratégias que nem sempre estão de acordo com o gênero solicitado, mas as que melhor atendam ao cumprimento do número de linhas. Ou seja, faz uma atividade de escrita, não uma produção de texto no qual ele é um autor que se dirige para um destinatário real.

O que dizer da terceira etapa apontada por Antunes (2003), e demais autores pesquisados, como uma das mais relevantes para trabalho com a escrita? A revisão? Falta um longo percurso para que o hábito de revisão e reformulação seja visto como algo produtivo, inerente à condição interativa da escrita, na qual mais de um sujeito é envolvido. A retextualização permite um diálogo com o outro ao mesmo tempo que denota uma preocupação com a melhoria do texto. Não para que seja um texto correto, mas compreensível e adequado ao seu objetivo comunicacional.

As condições dadas nessas avaliações não permitem ao enunciador selecionar o que dizer, possuir um motivo concreto para dizer a alguém (as avaliações não costumam circular fora do espaço da sala de aula), o próprio estudante ter o hábito de rever seu texto, nem haver tempo disponível para esse movimento, geralmente, todo o processo ocorre no máximo em duas aulas consecutivas, ou seja, menos de duas horas. Caso a revisão se faça após o momento da avaliação, os estudantes pressupõem que a nota já foi dada e não precisam refazer o texto. Estamos de acordo com Antunes (2003), quando diz que:

\footnotetext{
A prática da escrita das "redações" escolares - normalmente realizada num limite escasso de tempo, frequentemente improvisada e sem objetivos mais amplos que aquele de simplesmente escrever- leva os alunos a produzir textos de qualquer maneira, sem um planejamento prévio e, ainda, sem uma diligente revisão em busca da melhor forma de dizer aquilo que se pretendia comunicar. (ANTUNES, 2003.p.59, grifo da autora)
} 
A prática da escrita dessas "redações" deve ser substituída por propostas que correspondam aos diferentes usos sociais da escrita. Isso é um fato aceito por todos os pesquisadores do estudo do ensino da língua, mas que ainda não se concretiza na prática escolar, na qual os aspectos políticos e ideológicos primam por dados estatísticos.

A isso somam-se outros fatores que já são senso comum sobre as condições de trabalho dos professores, pois mesmo que saibam qual o melhor caminho a seguir, precisam assumir muitas turmas e não conseguem dar a devolutiva das atividades conforme seria o ideal. Além disso, essa prática de revisão que conduz o aluno a considerar um texto, primeiramente como um projeto inacabado e também, como um processo, deveria ser realizada desde os anos iniciais. Talvez o problema seja de mais um equívoco da interpretação de algumas teorias socioconstrutivistas divulgadas na década de 1990. O que se dizia na época, e até hoje é praticado por muitos professores alfabetizadores, é que não se poderia "corrigir" o texto do aluno, mas apenas considerar suas intenções, hipóteses.

\subsection{O TEXTO COMO OBJETO DE ENSINO}

Até agora discutimos como deve ser a prática de professores de língua portuguesa; reconhecemos que o trabalho com a escrita precisa ser fundamentado em uma abordagem interativa da língua, e que novas práticas devem substituir o tradicional ensino de gramática e a produção de unidades isoladas da língua. $O$ estudo da língua em uso dentre os teóricos da linguística não é um fato novo, mas dentro de um processo histórico é relativamente recente. No Brasil, somente no final do século $\mathrm{XX}$, começamos a discutir sobre as mudanças pedagógicas necessárias ao desenvolvimento pleno do sujeito.

Essas reflexões deram origem aos Parâmetros Curriculares Nacionais, doravante PCNs, documento que trouxe muitas mudanças quanto ao ensino da língua portuguesa. Após muitas críticas aos programas de ensino anteriores, o documento publicado em 1998, busca incorporar conceitos e procedimentos relativos aos mais recentes estudos da linguística. No corpo do texto não aparecem 
referências a nenhum autor ou teoria específica, mas podemos perceber que segue uma abordagem enunciativa-discursiva em várias partes do documento (Brait, 2000) Como, por exemplo, no trecho:

O domínio da linguagem, como atividade discursiva e cognitiva, e o domínio da língua, como sistema simbólico utilizado por uma comunidade linguística, são condições de possibilidade de plena participação social. Linguagem aqui se entende, no fundamental, como ação interindividual orientada por uma finalidade específica, um processo de interlocução que se realiza nas práticas sociais existentes nos diferentes grupos de uma sociedade, nos distintos momentos de sua história. (BRASIL, 1998, p.19)

Muda-se, assim, o enfoque do estudo na área de linguagens. A proposta do ensino passa a centrar-se no texto, como unidade básica do ensino e, não mais, nas unidades da língua como as letras, fonemas, sílabas, palavras, sintagmas, que tomadas sem um contexto, não colaboram com a competência discursiva. Além disso, o referencial considera a linguagem como um instrumento de inserção social que garante o exercício pleno da cidadania. Por isso, o domínio da língua em suas modalidades oral e escrita é um dos objetivos da disciplina língua portuguesa.

Vale lembrar que, para os PCNs:

Interagir pela linguagem significa realizar uma atividade discursiva: dizer alguma coisa a alguém, de uma determinada forma, num determinado contexto histórico e em determinadas circunstâncias de interlocução. Isso significa que as escolhas feitas ao produzir um discurso não são aleatórias ainda que possam ser inconscientes -, mas decorrentes das condições em que o discurso é realizado. (BRASIL,1998, p.20-21)

Como vimos anteriormente, as reflexões sobre as atividades com a escrita devem considerar o processo de interlocução para que os alunos produzam textos que os representem como sujeitos da aprendizagem, enunciando seu ponto de vista e posicionando-se criticamente em relação ao ponto de vista alheio.

Antes de passarmos para o conceito de gêneros discursivos, cabe ainda uma reflexão sobre o que os PCNs conceituam como texto:

O discurso, quando produzido, manifesta-se linguisticamente por meio de textos. Assim, pode-se afirmar que texto é o produto da atividade discursiva oral ou escrita que forma um todo significativo e acabado, qualquer que seja sua extensão. É uma sequência verbal constituída por um conjunto de relações que se estabelecem a partir da coesão e da coerência. Esse conjunto de relações tem sido chamado de textualidade. Dessa forma, um texto só é um texto quando pode ser compreendido como unidade significativa global, quando possui textualidade. Caso contrário, não passa de um amontoado aleatório de enunciados. (BRASIL,1998,p. 21) 
Não pretendemos aqui esgotar a discussão quanto aos conceitos de texto, pois não caberia neste trabalho todas as vertentes do tema. Tomamos aqui o conceito trazido pelos PCNs, que comunga também com Geraldi (1991) ao afirmar que "um texto é o produto de uma atividade discursiva onde alguém diz algo a alguém" e reafirmado por Antunes (2003) na seção anterior.

Se o texto é uma atividade discursiva e se realiza em condições comunicativas específicas, por meio de enunciados adequados a cada situação, chegamos à conclusão de que não podemos eleger um texto modelar para ensinar os alunos a ler e escrever. Essa conclusão não é nossa, e sim, o resultado de inúmeras pesquisas no campo da linguística. Por isso, incorporaram-se aos documentos oficiais orientações para subsidiar a prática pedagógica centrada não só no texto, mas nas condições de uso da língua em relação às diversas situações comunicativas.

\subsubsection{OS GÊNEROS DO DISCURSO COMO OBJETO DE ENSINO}

Assim como nos documentos oficiais em âmbito Nacional, PCNs e Diretrizes Curriculares Nacionais, o Currículo do Estado de São Paulo traz orientações voltadas para a tomada do texto como objeto de ensino. Mas ao tratar dos gêneros discursivos/textuais, em muitos momentos, ocorrem equívocos, confundindo tipologia e gêneros.

Assumimos aqui, como dito anteriormente, a perspectiva bakthiniana sobre gêneros do discurso, na qual, estes são constituídos como tipos relativamente estáveis de enunciados, utilizados em determinado campo de uso da língua. Nesse contexto, cada situação comunicacional mobiliza um conteúdo temático, um estilo e uma construção composicional específica. Sendo assim, os gêneros existem em grandes quantidades, pois são muitas as interações comunicativas realizadas pelo ser humano.

Os PCNs ao conceituarem gêneros o fazem da seguinte forma: 
discursos, as quais geram usos sociais que os determinam. Os gêneros são, portanto, determinados historicamente, constituindo formas relativamente estáveis de enunciados, disponíveis na cultura. São caracterizados por três elementos:

- conteúdo temático: o que é ou pode tornar-se dizível por meio do gênero;

- construção composicional: estrutura particular dos textos pertencentes ao gênero;

- estilo: configurações específicas das unidades de linguagem derivadas, sobretudo, da posição enunciativa do locutor; conjuntos particulares de seqüências que compõem 0 texto etc. (BRASIL,1998, p.21)

Percebemos que a definição de gênero se aproxima da teoria bakhtiniana de gêneros discursivos, mas no corpo do texto não aparecem referências ao autor. Outro aspecto a ressaltar, neste trecho, é a referência às sequências, que em nota de rodapé são traduzidas como narrativas, descritivas, argumentativas, expositivas e conversacionais. Esse fato pode ter ocasionado alguns equívocos na preparação de materiais didáticos e na condução de atividades de escrita nas quais é vinculado um gênero a uma tipologia textual.

Marcuschi (2008) faz uma distinção básica entre esses dois conceitos, ou seja, tipos textuais caracterizam-se como sequências linguísticas, envolvendo em sua composição aspectos lexicais, sintáticos, tempos verbais, relações lógicas e estilo. Já o gênero textual são "textos materializados em situações comunicativas recorrentes" (MARCUSCHI, 2008.p.155). Enquanto a tipologia textual apresenta poucas categorias: narração, argumentação, exposição, descrição, injunção; os gêneros textuais são inúmeros, pois são muitas as situações comunicacionais.

Não entraremos em debate, aqui, sobre outras divergências terminológicas quanto ao gênero textual/discursivo, pois, além de ser uma discussão não pertinente a este trabalho, nosso interesse maior é observar como o aluno constrói seu discurso dentro dos gêneros apresentados.

É importante destacar o conceito e a diferença entre gêneros primários (simples) e secundários (complexos), pois a partir desses aspectos poderemos analisar as condições de produção dos textos dos alunos.

Os gêneros primários são definidos por Bakhtin (2003) como aqueles que são realizados em situações de comunicação discursiva imediata, ou seja, são gêneros do cotidiano. Como por exemplo: diálogo, comentário, conversa informal ou íntima, etc. A estes, todos os usuários da língua têm acesso, independentemente de escolarização ou classe social. 
Já os gêneros secundários (complexos) são frutos de um convívio cultural mais complexo e, relativamente, muito desenvolvido e organizado. E, segundo o autor, os gêneros secundários, muitas vezes, são formados por gêneros primários que se revestem de um caráter especial, perdendo o vínculo imediato com a realidade concreta e os enunciados alheios. Essa reelaboração, às vezes não encontra eco nas produções de alunos, pois, ao compor um texto, que a princípio seria mais elaborado, os alunos o fazem de maneira mecânica, transcendendo a plasticidade do gênero solicitado.

Como lembra ROJO (2000), ainda há um longo percurso para que essas proposições para o trabalho com a língua sejam efetivadas. Desde a publicação dos trabalhos da autora com a formação dos professores para refletir sobre a prática dos PCNs, muito já foi feito dentro das políticas públicas, passando da inclusão das novas teorias linguísticas nos cursos de graduação até a implementação de cursos de mestrado profissional, como por exemplo o PROFLETRAS.

Como veremos na seção seguinte, os enunciados do outro são reelaborados para construir um enunciado particular, que comunica para um outro sua visão de mundo. As escolhas de unidades da língua são essenciais para compor um texto, mas o simples ato de escolher essa e não aquela já constitui uma subjetividade argumentativa. Esse processo de construção do pensamento e materialização em gêneros discursivos é, sem dúvida, um aspecto que merece um acompanhamento cuidadoso de professores de língua portuguesa. Buscamos, portanto, construir um referencial teórico que nos permitisse analisar as produções dos alunos.

\subsection{CRITÉRIOS PARA ANÁLISES}

Como nosso objetivo era desenvolver a argumentação e a cidadania representadas pelo gênero artigo de opinião, dentro de uma perspectiva enunciativa, elegemos alguns critérios para fundamentar nossa análise, procurando responder às seguintes questões:

i) Em que medida os alunos se beneficiaram das atividades propostas?

ii) Como o enunciado é construído pelo estudante em seus aspectos temáticos e composicionais, relativos ao gênero artigo de opinião? 
iii) Qual a influência do contexto de produção nos enunciados produzidos por eles?

Para atender tal propositura, apresentaremos, na próxima seção, alguns conceitos sobre argumentação e sua possível correspondência com textos produzidos por alunos em contexto escolar.

\subsection{1 - ASPECTOS ARGUMENTATIVOS DA LINGUAGEM}

Considerando que o artigo de opinião, como definimos anteriormente, é um gênero textual da esfera jornalística, com um papel social definido e constituindo-se como instrumento para o exercício da cidadania, devemos lembrar que o caráter argumentativo da língua é um aspecto fundamental a ser estudado em sala de aula.

Não há um discurso "neutro"; ainda que o enunciador não demonstre expressamente uma opinião, essa escolha determina, talvez, sua dúvida em relação ao que deveria fazer ou pensar, por isso Koch (2011) afirma que todo ato linguístico é um ato de argumentar.

Reconhecer esse aspecto argumentativo da linguagem não é suficiente para produzir bons textos, pois, conforme os gêneros, o emprego de algumas técnicas argumentativas supera o simples conhecimento dos significados das palavras.

Desde a antiguidade, o estudo de técnicas argumentativas foi objeto de interesse de filósofos e estudiosos, pois o debate e o discurso eram responsáveis pela tomada de decisões sociopolítico-econômicas. Como todo discurso é materializado por textos, esses estudos filosóficos também são de interesses de linguistas e demais profissionais da área.

Além da leitura da Retórica de Aristóteles, fomos buscar na obra de Perelman \& Olbrechets-Tyteca (1996), Tratado da Argumentação. A Nova Retórica, alguns conceitos que nos ajudaram a refletir sobre a construção da argumentação em textos escritos por nossos estudantes.

O primeiro ponto de articulação encontrado entre essa teoria e os os estudos de produção de texto é o que se refere à construção do auditório. Para argumentar é necessário conhecer as origens psicológicas e sociológicas do outro a quem o 
enunciador está se dirigindo. Os autores apontam que a generalização pode levar à artificialidade dos temas, muito comum em atividades escolares.

Outro aspecto que se relaciona com os textos de adolescentes, é o fato de alguns discursos serem inflamados por uma paixão que ignora o ponto de vista do leitor. O enunciador apaixonado acredita que os argumentos que o convenceram, também convencerão o "auditório". Isso é apontado pelos autores como uma má escolha de razão e não como uma ausência de razão. Ocasionalmente, por esse motivo, o enunciador pode abrir mão de persuadir para não renunciar às suas convicções.

Na concepção dos autores, o conceito de convencer e persuadir são distintos; o primeiro estaria voltado a um auditório universal e o segundo a um auditório particular. Isso nos leva a uma reflexão sobre como o aluno elege seu auditório em uma situação de avaliação de produção de texto argumentativo.

Segundo a Nova Retórica, o auditório caracteriza-se por três tipos básicos: universal - compreende todos adultos em geral; particular- um grupo específico, e o próprio sujeito. No momento da produção, o estudante pode determinar, consciente ou inconscientemente, um tipo de auditório e escolher estratégias para convencer (universal) ou persuadir (particular). Pode também eleger-se a si mesmo para deliberar suas ideias. Todavia, essa decisão é sempre confrontada com as informações da proposta de produção textual e, não havendo correspondência, há um uso corrente na escola: desvalorizar o que o aluno escreveu. Deveríamos, nesta situação, orientar os alunos a fazer as escolhas mais adequadas ao gênero e leválos a refletir sobre o contexto de recepção do seu texto.

Perelman \& Olbrechts-Tyteca (1996, p.61), afirmam que "a argumentação é uma ação que tende sempre a modificar um estado de coisas preexistente". Essa modificação se dá por meio de um debate no qual o orador deve envolver o ouvinte para que este comungue com ele o seu pensamento. Este aspecto é relegado por muitos enunciadores jovens que escrevem agressivamente para reforçar seus valores. Essa atitude pode ter força argumentativa, pode até convencer, mas nem sempre consegue persuadir, pois não obtém a adesão do auditório/leitor.

Alguns procedimentos adotados em situações pedagógicas são confrontados pelo estudo da Nova Retórica, como, por exemplo, ao ensinarmos os alunos a argumentar, solicitar que eles justifiquem sua opinião. Nem sempre a justificativa 
colabora para o aspecto argumentativo, pois um fato justificado pode ter seu estatuto diminuído e deixar a falsa ideia que ele pode ser presumido pelo enunciador.

Quando analisamos o caráter argumentativo, devemos observar diversos fatores que contribuem para convencer ou persuadir o leitor. Um desses fatores é a atribuição de valores aos argumentos. A hierarquia que o enunciador dá a determinados conceitos indica para qual direção pretende levar seu leitor.

O uso de lugares-comuns, ou como conhecemos, argumentos baseados em senso comum, podem ter forte ação persuasiva se pensarmos que o enunciador faz seu texto para um auditório universal; assim, se o conceito é aceito pela maioria, também será aceito pelo destinatário.

A escolha de um ponto de vista, evidenciada na literatura do gênero artigo de opinião pode ser questionada se levarmos em conta que:

Por vezes, o esforço daqueles que argumentam não visa tanto impor uma
determinada interpretação como mostrar a ambiguidade da situação e as
diversas maneiras de compreendê-la. O fato de conceder sua preferência a
uma certa interpretação ou mesmo o de crer na existência de uma única
interpretação válida podem ser reveladores de um sistema particular de
crenças ou até de uma concepção do mundo. (PERELMAN, OLBRECHTS-TYTECA, 1996, p.138-139)

Sendo assim, às vezes, o que vimos como incoerência em algumas produções revela justamente a posição de não querer aderir a esse ou a outro lado de uma questão. Não deixa, entretanto, de ser argumentativo, pois não existe enunciado neutro, podendo assumir um caráter persuasivo, como por exemplo, jovens que comungam o pensamento de não se interessar por questões políticas.

Independentemente de todos os aspectos até aqui levantados, um conceito consolidado por todos que se dedicam ao estudo da língua é o fato de o texto escrito não dispor dos mesmos recursos do discurso falado. Ao se falar em auditório, nos textos filosóficos, pensamos primeiramente em um interlocutor imediato, percebedor das intenções linguísticas, apoiado tanto pela entonação quanto por outros recursos da fala do enunciador. Em se tratando de textos escritos, a interpretação depende tanto dos aspectos pragmáticos, quanto dos semânticos-sintáticos. As marcas linguísticas deixadas pelos enunciador, em momento que fica distante da leitura, poderão produzir efeitos persuasivos em maior ou menor grau, dependendo das escolhas e das estratégias utilizadas pelo enunciador. 
Diante do exposto neste capítulo, compreendemos a importância da reflexão sobre a prática pedagógica. Percebemos que a partir da década de 90 essa reflexão se tornou mais profícua, trazendo grandes contribuições para as pesquisas linguísticas nas escolas brasileiras, conforme exposto nos trabalhos de Pimentel (1998), Grillo (1995), Schiavoni (2009), Rojo (2000) e Brito (2011).

A publicação dos PCNs subsidiou, em grande parte, as transformações ocorridas nas práticas docentes nos últimos anos. O estudo da língua passou a ter o texto como objeto de aprendizagem, obrigando, dessa maneira, alterações de ordem conceituais em todos os materiais didáticos. A linguística textual, a análise discursiva e as considerações sobre gêneros textuais/discursivos estão presentes tanto em livros didáticos, em materiais de apoio quanto nas atividades propostas em sala de aula.

Entretanto, não são poucas as dificuldades encontradas para a consolidação dessas mudanças. Há um processo em curso: o da formação de profissionais conscientes de seu papel como agentes transformadores.

Os apontamentos feitos por Antunes (2003) reforçam a necessidade do planejamento de práticas que favoreçam o domínio da língua na sua modalidade escrita. Nesse planejamento, deve-se considerar o conceito de enunciados bakthinianos, visto que o domínio de um gênero secundário passa pela apropriação de outros enunciados. Nessa perspectiva, as considerações de Geraldi (1991) e Antunes (2013) sobre apresentar para o sujeito da aprendizagem outros textos são fundamental para que ele se aproprie de outros enunciados e tenha o que dizer para o seu destinatário. Conhecer o gênero a ser produzido é de suma importância nesse processo, pois as escolhas linguísticas do enunciador dependem desse conhecimento.

Se considerarmos que a língua é constituída por um processo interativo de enunciados, como ela é de fato, devemos proporcionar oportunidades para que o aluno desenvolva suas habilidades também de forma processual. A aprendizagem de estratégias de escrita deve ser vista como parte de um percurso que culminará na formação de um sujeito competente nessa modalidade de comunicação verbal.

No próximo capítulo, explicitaremos a metodologia de pesquisa e abordaremos alguns conceitos sobre o gênero textual/discursivo artigo de opinião. 


\section{CAPÍTULO 2}

\section{METODOLOGIA: REFLEXÃO SOBRE ENSINO}

Este capítulo objetiva apresentar os princípios metodológicos que orientaram e organizaram o trabalho de sala de aula. Em primeiro lugar, justificamos a relevância de atividades com gêneros argumentativos para desenvolvimento das habilidades linguísticas dos estudantes, necessárias ao pleno exercício de sua cidadania. A exposição dos princípios estruturadores das sequências didáticas, tal como foram formuladas pelos teóricos suíços, Dolz e Shneuwly, permitiu uma organização da prática pedagógica, com vistas a diagnosticar as competências e habilidades de escrita para, em seguida, propor ações superadoras do quadro inicial. Por fim, foi necessário caracterizar o gênero argumentativo "artigo de opinião", com base em bibliografia pertinente sobre o tema.

\section{1 . POR QUE OS GÊNEROS ARGUMENTATIVOS NA ESCOLA?}

Nas últimas décadas, no Brasil, tem-se repensado o ensino da língua nas aulas de língua portuguesa. Apesar de a teoria dos gêneros do discurso não ser relativamente nova, somente após a publicação dos PCNs (1998), iniciou-se a discussão sobre a aplicação dos gêneros na sala de aula. A língua em uso passou a ser o objeto de estudo, deixando de ser vista como um sistema estático de signos que os alunos precisariam dominar. Entretanto, para efetivar esse aprendizado é necessário revermos as práticas de sala de aula. Oferecer ao aluno atividades de leitura e de produção de textos variados, que circulam nas várias esferas sociais, é um dos meios de instrumentalizar o aluno para praticar a língua. Isso está relacionado com a educação porque a

...concepção interacionista, funcional e discursiva da língua, da qual deriva o princípio geral de que a língua só se atualiza a serviço da comunicação intersubjetiva, em situações de atuação social e através de práticas discursivas materializadas em textos orais e escritos (ANTUNES, 2003, p. 42). 
Essas práticas discursivas se traduzem em gêneros textuais, à medida que atendem às necessidades de comunicação. Apoiamo-nos na concepção de Bakthin (2003), na qual os gêneros do discurso são tipos relativamente estáveis de enunciados, produzidos nas mais diversas esferas de comunicação e também no postulado em Bazerman (2011, p:32, grifos do autor), em que gêneros são "fenômemos de reconhecimento psicossocial que são parte de processos de atividades socialmente organizadas". Segundo este, os gêneros emergem na prática social para que as pessoas possam interagir e compartilhar significados conforme os seus propósitos práticos; por isso, reconhecer as características comuns a um determinado gênero é insuficiente para classificá-lo. Muitas vezes, é o que ocorre na prática de sala de aula. Induzidos por materiais didáticos e orientações pedagógicas equivocadas, nós, professores, buscamos uma fórmula de se ensinar um gênero. Dado o contexto de produção de cada um deles, é preciso ir além do texto, explorar a situação social na qual são empregados, comparar e analisar questões discursivas, explorar os aspectos temáticos, composicionais e estilísticos.

Se cada gênero possui uma relativa estabilidade e novos gêneros são criados a partir dos já existentes, quanto mais se expande a aprendizagem de gêneros na escola, será facilitada a relação do aluno com textos novos ou desconhecidos por ele. Fazer uma seleção é tarefa difícil para os professores, mas é certo que o papel da escola é oportunizar o contato dos aprendizes com aqueles necessários ao seu pleno desenvolvimento intelectual, social e cultural. Entretanto, como afirma Alves (2011, p. 65) "escolher um gênero não se reduz a escolher apenas um conjunto de textos, mas trazer à tona aspectos sociais, culturais e políticos associados."

Em meio à pluralidade de gêneros que permeiam a vida social, o trabalho escolar com os textos argumentativos, recomendados pelos PCNs, desponta como possibilidade de inserção social, pois, como lembra Rosenblat (2000, p.185)

...tomemos os discursos argumentativos como um conjunto de gêneros que faz funcionar grande parte das relações sociais, já que, em última instância, são argumentos (ditos e/ou implícitos) que parametrizam as regras e valores de grupos sociais e que, portanto, orientam os comportamentos dos indivíduos que os compõem.

Sendo assim, os PCNs (BRASIL,1998, p. 40) incentivam a "possibilidade de o aluno poder expressar-se autenticamente sobre questões efetivas". O documento ainda aponta para a relevância do trabalho com os textos argumentativos, pois 
dessa maneira o aluno pode exercer sua cidadania, reconhecer a argumentação em vários âmbitos da vida social e posicionar-se de forma crítica ante as questões sociais, presentes em enunciados de diversos gêneros veiculados na sociedade.

Nesse sentido, cabe à escola inserir gêneros de todas as esferas sociais e subsidiar a aprendizagem do aluno para que se torne um cidadão participativo da comunidade. Cientes, por um lado, da importante função social dos gêneros argumentativos e, por outro, pressionados pelas avaliações externas propostas pela Secretaria de Educação ${ }^{1}$, consideramos relevante o desenvolvimento de atividades pedagógicas com o gênero artigo de opinião, presente na esfera jornalística.

O domínio de um gênero, em especial o argumentativo, promove autonomia para o aluno usar a língua de forma eficiente, como nos lembra Koch e Elias:

Dominar um gênero consistiria no próprio domínio da situação comunicativa,
domínio esse que se pode dar por meio do ensino das aptidões exigidas
para a produção de um gênero determinado. O ensino dos gêneros seria,
pois, uma forma concreta de dar poder de atuação aos educadores e, por
decorrência, aos seus educandos. (KOCH e ELIAS, 2012, p.61)

Toda situação comunicativa revela uma argumentatividade, que Koch (2002, p. 17, grifos da autora) define como: "o ato de argumentar é visto como o ato de persuadir que procura atingir a vontade, envolvendo a subjetividade, os sentimentos, a temporalidade, buscando adesão e não criando certezas". Essas são características defendidas pelos PCNs para que o aluno seja participativo e crítico em seu contexto social. Ainda conforme Koch (idem; p.15), "a linguagem passa a ser encarada como forma de ação, ação sobre o mundo dotada de intencionalidade, veiculadora de ideologia, caracterizando-se, portanto, pela argumentatividade".

A melhor alternativa para trabalhar o ensino de gêneros textuais é envolver os alunos em situações concretas de uso da língua, de modo que consigam, de forma criativa e consciente, escolher meios adequados aos fins que se deseja alcançar. É necessário ter a consciência de que a escola é um "autêntico lugar de comunicação" e que as situações escolares "são ocasiões de produção e recepção de textos" (DOLZ E SCHNEUWLY, 2004, p. 78).

\footnotetext{
${ }^{1}$ A avaliação da aprendizagem em processo (APP) realizada no início do primeiro e do segundo semestres, bem como a prova do Saresp (Sistema de Avaliação do Rendimento Escolar de São Paulo) propõem a produção de artigo de opinião.
} 


\section{2 - SEQUÊNCIA DIDÁTICA COMO ESTRATÉGIA DE ENSINO.}

Encontramos nos trabalhos dos estudiosos suíços, a concepção de sequências didáticas que, a partir de agora serão denominadas de SD, como "um conjunto de atividades escolares organizadas, de maneira sistemática, em torno de um gênero textual oral ou escrito. " (DOLZ E SCHNEUWLY 2004, p. 82). Segundo eles, a sequência permite ao aluno escrever ou falar de uma maneira mais adequada em cada contexto social, pois sua finalidade é ajudar o aluno a dominar melhor um gênero de texto, isto é, a SD permite o desenvolvimento de habilidades de leitura e escrita.

Além de perceber as regularidades de um determinado gênero, é preciso ter o que dizer para produzir o próprio texto. Familiarizar-se com a estrutura é só um primeiro passo para compreender as especificidades de um gênero. Como afirma Bazerman (2011), quando se cria uma identidade com a escrita de um determinado texto, as atividades inerentes ao seu contexto podem ser praticadas e revistas pelos produtores. Entretanto, para que isso ocorra é preciso que eles entrem em contato com vários exemplares e passem a se identificar com o contexto de produção desse gênero. Por isso, entre outros motivos, a organização de uma SD foi escolhida como estratégia de ensino-aprendizagem para otimizar esse processo.

\subsection{1- SEQUÊNCIA DIDÁTICA- GRUPO DE GENEBRA}

Os componentes de uma sequência didática, conforme Dolz e Schneuwly (2004) são:

Apresentação da situação: exposição detalhada para os alunos da tarefa de expressão oral ou escrita que será realizada e preparação para a produção inicial.

Produção inicial: primeira produção, oral ou escrita, permite avaliar os conhecimentos dos alunos em relação ao gênero proposto e as capacidades que precisam ser desenvolvidas; 
Módulos: são constituídos por atividades e exercícios diversificados que visam aprimorar o domínio do gênero textual em estudo. Nos módulos, são trabalhados os problemas detectados na produção inicial do texto. Cada módulo contemplará um dos problemas identificados e características do gênero, ou seja, sua estrutura composicional, seu conteúdo temático e seu estilo.

Produção final: é o momento em que o aluno coloca em prática os conhecimentos adquiridos e, junto com o professor, pode avaliar os progressos ocorridos.

Assim temos o esquema abaixo que representa a SD, segundo esses autores:

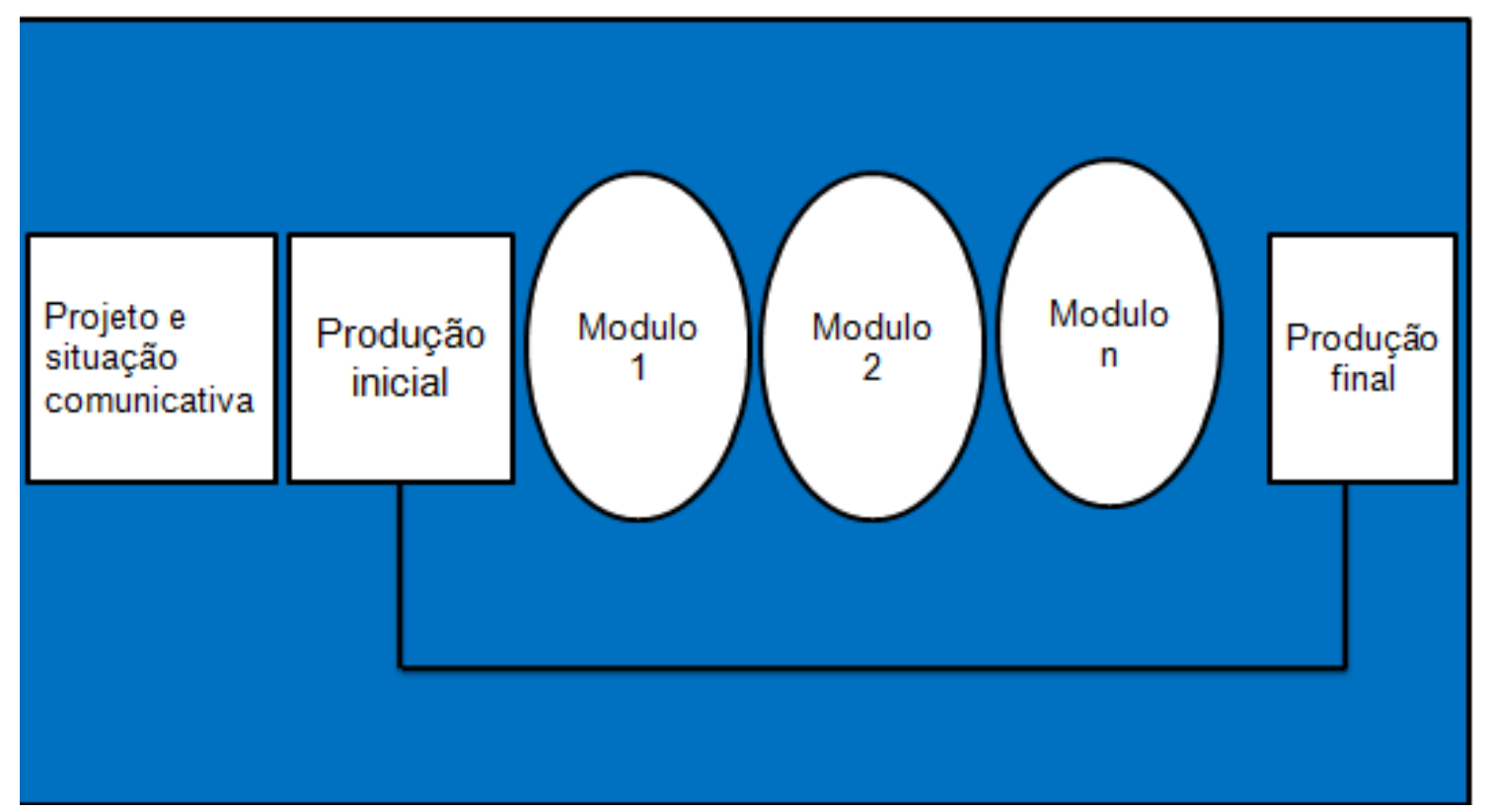

Figura Esquema da Sequência Didática- (DOLZ e SCHNEUWLY, 2004,p.83)

\subsection{TRANSPOSIÇÃO DIDÁTICA - SD}

A seguir, detalharemos cada um dos componentes da sequência didática e sua relação com o objetivo do trabalho de sala de aula e da pesquisa.

\subsubsection{APRESENTAÇÃO DA SITUAÇÃO}

É nesse momento que será explicitado ao aluno o projeto a ser desenvolvido, apresentando-se um problema comunicacional bem definido. Segundo os autores, "A apresentação da situação visa expor aos alunos um projeto de comunicação que 
será realizado "verdadeiramente" na produção final" (Dolz e Schneuwly, 2004, p.84). Ao mesmo tempo que os prepara para a produção inicial, ela determina o contexto de produção; o gênero a ser abordado, o público-alvo, a forma de veiculação, os sujeitos da produção.

Esta etapa foi comprometida, ou seja, não nos foi possível seguir as orientações do grupo de Genebra no que se refere à contextualização, pois como eram previstas duas avaliações durante o ano, pretendíamos tomar a primeira como a produção inicial. Entretanto, a distribuição das orientações para aplicação e o material direcionado aos alunos foram entregues com atraso e coincidiram com a data limite para aplicação da prova, prazo este estipulado pela Diretoria de Ensino. Esses entraves prejudicaram a contextualização da atividade e nos obrigaram a adequar a sequência de atividades às necessidades apresentadas pela turma.

\subsubsection{A PRODUÇÃO INICIAL}

Trata-se da primeira produção escrita feita pelos alunos, sendo fundamental para que se obtenham os dados que irão nortear o desenvolvimento dos módulos, pois, conforme Schneuwly e Dolz (2004), é a partir dela que o professor avaliará os conhecimentos da turma em relação ao gênero, bem como suas dificuldades. Constitui um momento de aprendizagem tanto para o professor quanto para o aluno, pois ambos podem perceber o que já sabem fazer e conscientizar-se dos problemas que eles encontram em relação ao objetivo da tarefa.

Como foi comentado anteriormente, a contingência de apresentar os resultados no prazo determinado alterou os procedimentos recomendados pelos teóricos, pois não houve tempo hábil para apresentar outros textos do gênero artigo de opinião, antes da produção inicial. A proposta da atividade consistia em apresentar dois textos motivadores sobre o tema a ser desenvolvido, porém um texto consistia em uma receita para se fazer pipa e o outro, num anúncio publicitário.

A seguir, reproduzimos a proposta tal como foi apresentada aos alunos: 
AVALIAÇÃO DA APRENDIZAGEM EM PROCESSO / LÍNGUA PORTUGUESA Produção Textual

9a ano do Ensino Fundamental

Turma

1ํsemestre de 2014

Data

Escola

Aluno

Caro aluno, você está recebendo o Caderno de Produção Textual. Leia, com atenção, as orientações, realize as atividades de cada etapa, com o(a) professor(a) e, por fim, escreva seu texto.

\section{ETAPA I}

Leia o texto e responda às atividades propostas:

Receita de pipa

Materiais

Duas varetas (uma maior e outra menor), uma folha de papel de seda, linha, cola e tesoura.

\section{Modo de fazer}

Posicione a vareta menor sobre a maior, perpendicularmente. Com a linha, amarre as varetas no centro e nas extremidades unindo todas as pontas.

Coloque o papel de seda sobre a armação e corte no formato da pipa, deixando 2 centímetros de sobra. Dobre essa borda e cole.

Amarre uma linha nas pontas da vareta menor, envergando-a. No centro dessa linha, amarre outra, que levantará a pipa.

\section{Como brincar}

Para que a pipa suba bastante, deixe-a contra o vento. Um amigo pode mantê-la levantada no início. Quando ela começar a voar, solte e movimente a linha para que ela permaneça no ar e faça diferentes manobras. Quem deixar a sua mais tempo no céu é o vencedor. Não vale usar cerol, que pode causar sérios ferimentos.

\section{Variações}

Papagaio, raia e pandorga são alguns dos outros nomes da pipa.

Fonte: Nova Escola. Brincadeiras Regionais - Nordeste. Ano XXVII n² 257. Fundação Victor Civita- Abril. Novembro de 2012, p. 76. (Adaptado)

Responda às questões abaixo referentes à ETAPA I.

1. Um texto prescritivo indica o que uma pessoa deve fazer para chegar a um resultado como, por exemplo, confeccionar algo. Assinale as alternativas cujas frases retiradas do texto "Receita de pipa" indicam o que se deve fazer para a confecção da pipa:

Figura 2- Proposta de produção textual - AAP- $1^{\circ}$ semestre 
(A) "Para que a pipa suba bastante, deixe-a contra o vento."

(B) "Posicione a vareta menor sobre a maior".

(C) "Coloque o papel de seda sobre a armação".

(D) "Amarre uma linha nas pontas da vareta menor".

2. Nas frases em que há indicações do que se deve fazer para confeccionar a pipa, os verbos estão geralmente no

(A) tempo presente.

(B) modo infinitivo.

(C) tempo passado.

(D) modo imperativo.

3. Quais elementos aproximam o texto "Receita de pipa" de uma receita culinária comum?

\section{ETAPA II}

Leia o texto e responda às atividades propostas:

Uma brincadeira que pode terminar em tragédia

Soltar pipas com segurança é muito mais divertido.

As férias estão chegando e você tem agora todo o tempo livre para muitas brincadeiras. Mas tome cuidado! Solte pipas em áreas abertas e distantes da rede elétrica para não se machucar.

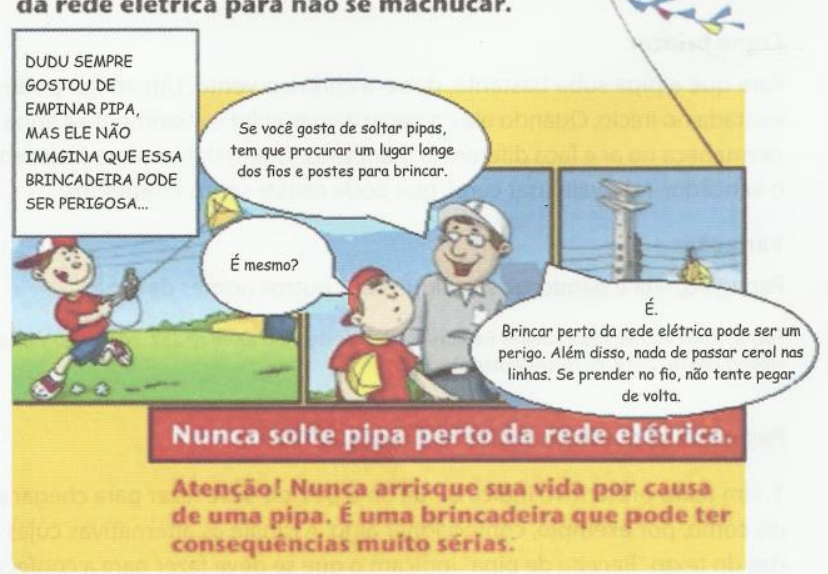

2 Avaliação de Produção Textual $-9^{\circ}$ ano do Ensino Fundamental

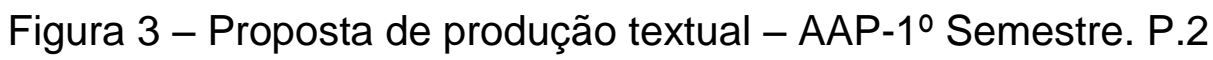


As pipas são um risco para os motociclistas e representam perigo até para quem não participa da brincadeira. Por exemplo, pessoas que se utilizam de moto para se locomover estão expostas à ameaça da linha com cerol. Na época das férias é comum ver crianças e adultos empinando pipa e arriscando a vida para correr atrás delas.

Por isso, fique ligado nessas dicas:

$\checkmark$ Soltar pipas perto da rede é muito perigoso. Elas podem enroscar nos fios, com risco de descarga elétrica. Materiais metálicos também não devem ser utilizados na fabricação desse brinquedo, pois conduzem eletricidade, aumentando a chance de choque elétrico.

$\checkmark$ Não toque em nenhum objeto estranho que esteja pendurado na rede elétrica como fios, pipas, entre outros.

$\checkmark$ O uso de cerol (pó de vidro com cola) oferece mais um risco: ele corta a camada de borracha que reveste os fios de alumínio ou de cobre, criando a situação de transferência de corrente elétrica. Além disso, o uso de cerol também pode provocar acidentes com motociclistas.

Disponivel em: <http://navenezadomarajo.blogspot.com.br/2012/06/uma-brincadeira-que-pode-termina-em.html>. Acesso em 06 de setembro de 2013. (Adaptado)

Responda às questões referentes ao texto da ETAPA II.

1. Qual é o assunto do texto?

2. A frase que apresenta o uso de verbo no imperativo, como utilizado em textos prescritivos, está presente em:

(A) "Não toque em nenhum objeto estranho".

(B) "Soltar pipas perto da rede é muito perigoso".

(C) "Elas podem enroscar nos fios com risco de descarga elétrica."

(D) "As pipas são um risco para os motociclistas..."

3. Que elementos aproximam os textos utilizados nesta etapa? O que os diferencia?

Figura 4- Proposta de produção textual - AAP-1ํ Semestre. P.3 


\section{ETAPA III}

Refletindo sobre o assunto...

1. Empinar pipas é só para meninos? O que vocês acham?

2. Afinal, porque se usa cerol nas linhas das pipas?

O professor irá orientá-los na realização de uma pesquisa para responder às questões apontadas.

\section{ETAPA IV}

\section{Agora é sua vez!}

Você leu um texto que fala dos perigos de empinar pipa utilizando cerol e outro que ensina como confeccionar pipas. Também realizou outras leituras, orientadas pelo professor. Após a realização das atividades propostas, elabore um texto de opinião, cujo tema é: Os benefícios e os males de se empinar pipa.

Lembre-se de utilizar argumentos a favor ou contra empinar pipa nos dias de hoje, deixando claro o que você pensa a respeito.

\section{Recomendações:}

1. Faça um rascunho.

2. Verifique se o leitor de seu texto compreenderá o que você escreveu.

3. Passe o rascunho a limpo, utilizando caneta azul ou preta.

4. Capriche na letra!

5. Não se esqueça do título.

6. Utilize uma folha de caderno para a produção textual.

4 Avaliação de Produção Textual - $9^{\circ}$ ano do Ensino Fundamental

Figura 5 - Proposta de Produção textual- AAP - 1ํㅡㄴ Semestre, p. 4

Ainda que as orientações fossem entregues antes do prazo de aplicação, que fossem realizadas as pesquisas sugeridas nas orientações dadas aos professores, que as atividades fossem bem desenvolvidas, a proposta de produção não deixa 
claro o gênero do texto a ser produzido. "...elabore um texto de opinião, cujo tema é: Os benefícios e os males de se empinar pipa." Qual texto é esse? Quem vai ler? Ele se parece com qual outro texto? A insuficiência de informações sobre o contexto de produção e caracterização do gênero levaram o aluno a produzir listas com motivos para se empinar pipa ou não. A ausência de uma argumentação consistente, assim como a forma composicional diversa do gênero do artigo de opinião motivou a reflexão sobre quais ações seriam necessárias para preparar os alunos à produzirem textos do gênero e, também, prepará-los para a segunda avaliação que ocorreria no início do segundo semestre.

Dolz e Schneuwly (2004) apontam para necessidade de se fazer uma categorização das dificuldades encontradas, ou seja, deve-se fazer uma correção criteriosa da primeira produção textual, elencando as dificuldades e agrupando-as conforme a natureza dos problemas identificados, como, por exemplo, a adequação ao gênero, à estrutura composicional, ao conteúdo temático, ao estilo, à coesão, à coerência etc.

\subsubsection{OS MÓDULOS}

Segundo a orientação dos autores, depois de categorizados na etapa anterior, os problemas que apareceram na produção inicial precisam agora ser superados, mediante a "instrumentação" dos alunos.

Tomando-se por base os níveis diferentes de problemas, serão desenvolvidas atividades diversificadas nos módulos, pois quanto mais se ampliam os tipos de exercícios, melhor a chance de atingir as dificuldades de todos os alunos. Entre as possibilidades de atividades, os autores sugerem com ênfase as "atividades de observação e de análise de texto" (Dolz e Schneuwly,2004, p.89), pois nelas a leitura analítica e/ou comparativa de textos do gênero estudado permite ao aluno compreender alguns aspectos textuais do funcionamento do gênero argumentativo.

Para compor as atividades dos módulos da sequência, foram considerados os materiais disponíveis e, após uma análise dos mesmos, resolvemos organizar o trabalho de forma a utilizar o que se tinha à mão e também preparar o que fosse necessário para atingirmos o nosso objetivo. 


\subsubsection{1. - MATERIAIS DISPONÍVEIS}

Para maior clareza, apresentamos o sumário do Caderno do professor Volume 1, do Governo do Estado de São Paulo. Ressaltamos que o caderno do aluno será priorizado, mas, como algumas informações aparecem somente no caderno do professor, à medida que for necessário, sinalizaremos a sua referência.

\begin{tabular}{|c|c|}
\hline $\begin{array}{l}\text { SUMÁRIO } \\
\text { Orientação sobre os conteúdos do volume } \\
\text { Situações de Aprendizagem }\end{array}$ & $\begin{array}{c}5 \\
9\end{array}$ \\
\hline Situação de Aprendizagem 1 - Traços característicos da tipologia "expo & 9 \\
\hline $\begin{array}{l}\text { Situação de Aprendizagem } 2 \text { - Traços característicos do } \\
\text { agrupamento tipológico "argumentar" }\end{array}$ & 19 \\
\hline $\begin{array}{l}\text { Situação de Aprendizagem } 3 \text { - O diálogo entre as tipologias } \\
\text { textuais na composição do gênero }\end{array}$ & 31 \\
\hline Situação de Aprendizagem 4 - Debater é mais do que trocar ideias & 40 \\
\hline Situação de Aprendizagem 5 - Recapitulando os conteúdos & 50 \\
\hline Proposta de situações de recuperação & 59 \\
\hline $\begin{array}{l}\text { Recursos para ampliar a perspectiva do professor e do } \\
\text { aluno para a compreensão do tema }\end{array}$ & 60 \\
\hline $\begin{array}{l}\text { Situação de Aprendizagem } 6 \text { - Da discussão coletiva à carta: } \\
\text { construindo a argumentação }\end{array}$ & 62 \\
\hline Situação de Aprendizagem 7 - Escrita de parágrafos argumentativos & 75 \\
\hline \multicolumn{2}{|c|}{$\begin{array}{l}\text { Situação de Aprendizagem } 8 \text { - Textos de opinião e seu contexto comunicacional } \\
83\end{array}$} \\
\hline Situação de Aprendizagem 9 - Produzindo um artigo de opinião & 94 \\
\hline Situação de Aprendizagem 10 - Recapitulando os conteúdos & 106 \\
\hline
\end{tabular}
Quadro 1 - Sumário Caderno do Professor 9 ano- Volume 1

O material está organizado em situações de aprendizagem, nas quais estão previstas atividades de leitura e de análise de texto; oralidade; estudo da língua. A 
produção escrita aparece em algumas delas. Embora nas orientações para o professor, existam indicações de que as atividades compõem uma sequência (no material é descrito como sequências de atividades), na prática nem sempre as escolhas dos temas e atividades possibilitam um trabalho efetivo com os gêneros. Como percebemos, no sumário, estão previstos vários gêneros dentro dos agrupamentos da ordem do expor e do argumentar.

$\mathrm{Na}$ situação de aprendizagem 1 são apresentados três textos: um verbete de enciclopédia, entrevista e artigo de divulgação científica. $\mathrm{Na}$ situação de aprendizagem 2 é sugerida uma música, à escolha do professor, uma crônica e dois textos verbo-visuais, todos eles com a temática de violência urbana. Ainda nessa situação é apresentada uma página de revista-Revista da semana, edição 11, ano 1 , 12 nov.2007.p 13- com dois textos de opinião com posições contrárias a respeito da pergunta/título da matéria $A$ inteligência é genética? A situação de aprendizagem 3 propõe o trabalho com resenhas críticas. Na situação de aprendizagem 4 é proposta a produção de um debate regrado sobre um tema polêmico. São dadas instruções para os alunos fazerem pesquisas e analisar textos sobre alguns temas. A situação de aprendizagem 5 é uma revisão dos conteúdos trabalhados até aquele momento.

Nesse conjunto, percebe-se a ênfase na tipologia e não em algum gênero específico, pois é solicitado ao aluno tecer um comentário sobre algumas imagens polêmicas, usando a exposição e a argumentação. Já na situação de aprendizagem 6, são oferecidos três textos com a mesma temática para serem analisados, sendo que, cada um deles, pertence a um gênero diferente: o texto 1-Insegurança de Contardo Calligaris- é trecho de um livro sobre adolescente; o texto 2- Atitudes que os pais devem adotar no tema das relações entre moças e rapazes adolescente- de Gerardo Castilho- é um trecho de livro de orientação sobre adolescentes; e o texto 3- E foi então que aconteceu- é um fragmento de romance de Jorge Miguel Marinho. Percebe-se ainda que nenhum dos textos propostos é integral, ou seja, o material didático é composto apenas de textos incompletos, privando o aluno do contato com o projeto de dizer integral do autor.

$\mathrm{Na}$ situação de aprendizagem 7 , na seção leitura e análise de texto, é apresentado o texto de Herbert de Souza, O poder do cidadão. Nas atividades de produção escrita, são sugeridas as atividades de produção de parágrafos argumentativos. Na situação de aprendizagem 8, é sugerida a exibição de um filme com tema polêmico e a pesquisa nas cartas de leitores, em revistas de informação 
(impressas ou virtuais) para serem analisadas. Na situação de aprendizagem 9, são analisados dois artigos de opinião sobre racismo no Brasil. Ambos foram retirados do jornal Folha de S. Paulo, Texto 1: Sim - O racismo como consequência - Antonio Sergio Alfredo Guimarães e Texto 2: Não- O tempo não para - Mary Lucy Murray Del Priore.

Procuramos expor aqui somente os gêneros trabalhados em cada situação para que tivéssemos uma perspectiva de como seria o trabalho se optássemos por utilizar, exclusivamente, o material oferecido pelo Estado. Além dos aspectos textuais, foram consideradas as atividades de análise que geralmente se resumem em elaboração de quadro síntese de informações sobre o texto. Assim como já destacamos, anteriormente, é possível perceber que são poucos os textos que foram reproduzidos na íntegra e não há nas atividades uma exploração do contexto discursivo de cada gênero apresentado.

A fim de completarmos a descrição dos materiais didáticos utilizados em sala de aula, é preciso apresentar, ainda, o livro didático adotado pela escola: Jornadas.port-9 ${ }^{\circ}$ ano- Editora Saraiva, que traz, em uma de suas unidades, o seguinte conteúdo: 


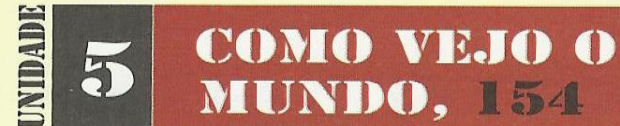

\author{
LEITURA 1 - Artigo de opinião (Mulheres \\ precisam querer mais, Luiza Nagib Eluf], 156 \\ Exploração do texto, 159 \\ Nas linhas do texto, 159 \\ Nas entrelinhas do texto, 159 \\ Além das linhas do texto, 159 \\ Como o texto se organiza, 161 \\ Recursos linguísticos, 165 \\ Depois da leitura - A literatura e a defesa de um ponto de \\ vista, 16? \\ Produção oral, 168 \\ Debate, 168 \\ Reflexão sobre a língua, 1?0 \\ Pronome relativo, 170 \\ Atividades, 174 \\ Fique atento... ao uso do pronome relativo onde, 1.75 \\ LEITURA 2 - Poema (Perguntas de um \\ trabalhador que lê, Bertolt Brecht], 17? \\ Exploração do texto, 178 \\ Do texto para o cotidiano (tema: influência da \\ propaganda), 180 \\ Produção escrita, 182 \\ Artigo de opinião, 182 \\ Reflexão sobre a língua, 184 \\ Oração adjetiva; tipos de oração adjetiva, 184 \\ Atividades, 186 \\ Ativando habilidades, 188
}

Figura 6 - Sumário da Unidade 5 do livro Jornadas. Port (DELMANTO e CARVALHO, 2012)

A partir da análise do material e das minhas considerações sobre os resultados com turmas anteriores, resolvemos aproveitar as atividades pertinentes do caderno do aluno, utilizar uma unidade do livro didático adotado pela escola Jornadas. Port - e também elaborar atividades extras para complementar o trabalho.

\subsubsection{2- REPRESENTAÇÃO DA SD}

Sendo assim a SD configurou-se desta maneira:

Situação inicial

Proposta da Avaliação de Aprendizagem em Processo (APP) 
Módulo 1

Produção de carta argumentativa- conhecendo o gênero argumentativo Módulo 2

Analisando um artigo de opinião

Módulo 3

Leitura de textos da mídia- produção de comentários- temática da copa do mundo

\section{Módulo 4}

Leitura e análise de textos argumentativos

Módulo 5

Leitura e análise de artigos de opinião

Produção intermediária de texto - Avaliação Bimestral

Produção final

Avaliação de Aprendizagem em Processo - 20 semestre

Dada a complexidade dos módulos, eles serão descritos e analisados no capítulo 5.

\subsubsection{A PRODUÇÃO FINAL}

Nessa etapa, o aluno tem a possibilidade de pôr em prática o que foi aprendido durante os módulos, ou seja, as noções e os instrumentos oferecidos a ele durante o processo. Cabe ao professor, também, realizar uma avaliação somativa, por meio da qual o aluno compreenda os critérios e possa perceber os elementos trabalhados em aula e seu desempenho na produção. Em relação a esse tipo de avaliação, relacionada ao desenvolvimento da SD, Dolz e Schneuwly apontam que:

Uma avaliação somativa assentada em critérios elaborados ao longo da sequência é mais objetiva, mas mantém sempre uma parte de subjetividade. Em vez de considerar a avaliação como um problema técnico de cotação, é preferível aceitar e assumir o caráter aproximativo inerente a qualquer aplicação de escalas de grades (seja qual for o grau de complexidade). A avaliação é uma questão de comunicação e de trocas. Assim, ela orienta os professores para uma atitude responsável, humanista e profissional. Frisemos, ainda, que esse tipo de avaliação será realizado, 
em geral, exclusivamente sobre a produção final" (DOLZ e Schneuwly, 2004, p. 91)

O processo avaliativo, como bem mostram os autores, não pode ser tomado unilateralmente. Deve-se promover a avaliação tanto do aluno, como do professor e também, por que não, do procedimento. Nessa avaliação da produção final, pode-se chegar a um resultado conclusivo das ações que deverão ser tomadas a partir desse momento. Há várias possibilidades, entre elas, a elaboração de outra SD para sanar as dificuldades encontradas pela maioria dos alunos, que podem ser: o não domínio da estrutura composicional, o uso da linguagem inadequada ou outra dificuldade específica da turma.

A nossa produção final será tomada com a aplicação da AAP do segundo semestre, prevista para o mês de agosto. Sendo assim, conforme os resultados observados nos textos dos alunos, outros encaminhamentos podem ser tomados até que se conclua o ano letivo.

\section{4 - JUSTIFICATIVA DA METODOLOGIA ESCOLHIDA}

Toda e qualquer escolha na educação deve seguir princípios norteadores claros, por isso não se pode escolher um procedimento aleatoriamente e "testar" com os alunos. A fundamentação teórica deve balizar a ação educativa por questões de eficácia e eficiência. Considerando que o objeto de trabalho é um ser humano, não podemos submetê-lo a situações experimentais sem, pelo menos, um mínimo de reflexão e estudo.

Para isso, ZABALA (1998) orienta que é necessário fazer algumas perguntas para reconhecer a validade da SD:

Na sequência didática existem atividades:

a) Que nos permitam determinar os conhecimentos prévios que cada aluno tem em relação aos novos conteúdos de aprendizagem?

b) Os conteúdos são propostos de forma que sejam significativos e funcionais para os meninos e meninas?

c) Que possamos inferir que são adequadas ao nível de desenvolvimento de cada aluno?

d) Que representem um desafio alcançável para o aluno, quer dizer, que levem em conta suas competências atuais e as façam avançar com a ajuda necessária; portanto, que permitam criar zonas de desenvolvimento proximal e intervir? 
e) Que provoquem um conflito cognitivo e promovam a atividade mental do aluno, necessária para que estabeleça relações entre os novos conteúdos e os conhecimentos prévios?

f) Que promovam uma atitude favorável, quer dizer, que sejam motivadoras em relação à aprendizagem dos novos conteúdos?

g) Que estimulem a auto-estima e o autoconhecimento em relação às aprendizagens que se propõem, quer dizer, que o aluno possa sentir que em certo grau aprendeu, que seu esforço valeu a pena?

h) Que ajudem o aluno a adquirir habilidades relacionadas com 0 aprender a aprender, que the permitam ser cada vez mais autônomas em suas aprendizagens?

(ZABALA, 1998, p. 64)

As atividades escolhidas atenderam a maior parte dessas perguntas. Os textos selecionados para serem trabalhados na SD foram aqueles cujo tema se aproximava da realidade e do interesse dos alunos. Além disso, DOLZ e SCHNEWLY (2004) classificam as escolhas em três tipos: pedagógicas, psicológicas e linguísticas.

As pedagógicas devem contemplar procedimentos que facilitem a avaliação formativa; motivem os alunos a escrever ou tomar a palavra, utilizando-se de linguagem apropriada; proponha atividades e exercícios diversificados para maximizar a aprendizagem e utilização dos instrumentos propostos.

As escolhas psicológicas são as relacionadas às atividades de produção, nas quais deve ser possível aos alunos não só a colocação de frases, mas a construção do discurso inserido em situação de comunicação social com toda a sua complexidade. Visa transformar o modo de falar e escrever dos alunos, adequandose ao público, posicionando-se em relação ao conteúdo, ampliando seu comportamento e consciência diante de um tema. Isso deve ocorrer se a SD oferecer os instrumentos adequados à transformação do aluno.

O aspecto linguístico diz respeito aos instrumentos linguísticos apresentados, por meio dos quais se produzem os textos e discursos. O aluno pode compreender as unidades linguísticas e sua relação com a estrutura do gênero estudado e poderá verificar quais se adequam àquele gênero ou não.

Mesmo com todos esses cuidados e observações dos teóricos, à medida que a SD foi sendo realizada e as disciplinas cursadas, observou-se que algumas escolhas poderiam ter sido outras, que as abordagens das atividades poderiam atender mais ao aspecto discursivo se fossem elaboradas conforme os autores estudados no curso. Enfim, o curso de mestrado profissional possibilita uma real análise da prática sob a ótica de pressupostos teóricos pertinentes à área do 
conhecimento a qual se destina. Em nosso caso, ao estudo dos processos de ensino-aprendizagem da língua portuguesa na sala de aula.

\section{5 . CONSIDERAÇÕES SOBRE OS GÊNEROS ARGUMENTATIVOS- ARTIGO DE OPINIÃO}

Levando-se em conta que o currículo do $9^{\circ}$ ano do Ensino fundamental prevê o trabalho com gêneros argumentativos, desde o primeiro bimestre e considerando que as avaliações externas (AAP e SARESP) requerem a produção do artigo de opinião como forma de avaliação de produção textual, a SD terá como objetivo levar o aluno a produzir um artigo de opinião. Entretanto, é válido ressaltar que se trata de uma abordagem inicial, pois as séries seguintes retomarão esse conteúdo e as habilidades serão desenvolvidas ao longo do ensino médio.

Como se trata de um gênero não familiar ao aluno, com circulação no meio jornalístico e ao qual muitos não têm acesso, o conhecimento das suas especificidades é imprescindível para o desenvolvimento do trabalho.

Segundo, Boff, Köche e Marinello (2009, p. 3)

O artigo de opinião é um gênero textual que se vale da argumentação para analisar, avaliar e responder a uma questão controversa. Ele expõe a opinião de um articulista, que pode ou não ser uma autoridade no assunto abordado. Geralmente, discute um tema atual de ordem social, econômica, política ou cultural, relevante para os leitores.

Outra definição que orientou a pesquisa foi de Rodrigues ${ }^{2}$ (2001, apud COSTA, 2013, p.57.), em que o artigo de opinião:

\footnotetext{
"é definido pela instância jornalística e pela esfera acadêmica como o gênero cuja finalidade discursiva da interação social é a manifestação de um ponto de vista, um comentário a respeito dos acontecimentos sociais do universo temático jornalístico, que apresenta aos leitores uma determinada orientação apreciativa, cuja autoria representa uma pessoa externa à empresa jornalística."
}

2 RODRIGUES, Rosângela Hammes. A constituição e o funcionamento do gênero jornalístico: cronotopo e dialogismo, Tese (Doutorado em Linguística Aplicada e Estudos da Linguagem). PUC, São Paulo, 2001. 
Isto posto, podemos afirmar que o gênero, em questão, corresponde aos objetivos postulados pelos PCNs, pois sendo um comentário a respeito de determinado tema, obriga a tomada de posição crítica em relação aos fatos ocorridos na sociedade. A consciência de que o tema está relacionado ao interesse do autor e este deve procurar convencer ou persuadir o interlocutor sobre seu ponto de vista é uma marca dos artigos de opinião.

Assim, "O horizonte temático do artigo refere-se a acontecimentos sociais próprios do universo da comunicação jornalística, mas que estão vinculados ou dizem respeito à esfera de atuação profissional do autor" (RODRIGUES, 2005, p.173). Segundo a autora, é a partir desse lugar que o autor responde aos acontecimentos sociais.

Bräkling (2000) também define o artigo de opinião como um gênero do discurso que se utiliza da argumentação para defender a posição assumida pelo produtor e refutar as possíveis opiniões divergentes. Segundo a autora, é um processo que prevê uma operação constante de sustentação de afirmações realizadas, sendo que a consistência dos dados determina o convencimento do interlocutor. Para isso, a dialogicidade e a alteridade estão presentes, pois somente é possível escrever um texto, no gênero, se conseguir colocar-se no lugar do outro, antecipando suas posições para refutá-las, negociando para influenciar sua opinião.

Para trazer ao aluno o contexto de produção dos artigos e os critérios adotados pelos veículos de comunicação de massa, nos quais esses são divulgados, buscamos informações pertinentes ao assunto. Essas recomendações estão presentes nos manuais de redação dos jornais brasileiros de grande circulação. O Manual da Redação da Folha de S. Paulo sugere que a criatividade não pode substituir a clareza, a objetividade e um bom domínio da língua, definindo o artigo de opinião como:

artigo - Gênero jornalístico que traz interpretação ou opinião do autor. Sempre assinado. Pode ser escrito na primeira pessoa. A Folha só publica artigos inéditos no Brasil ou, em ocasião excepcional, no mesmo dia que outra publicação. O jornal tem por norma editar artigos que expressem pontos de vista diferentes sobre um mesmo tema. (Folha se S. Paulo, 1992) 
O caderno do professor, parte do material didático fornecido pela Secretaria do Estado, caracteriza o gênero como:

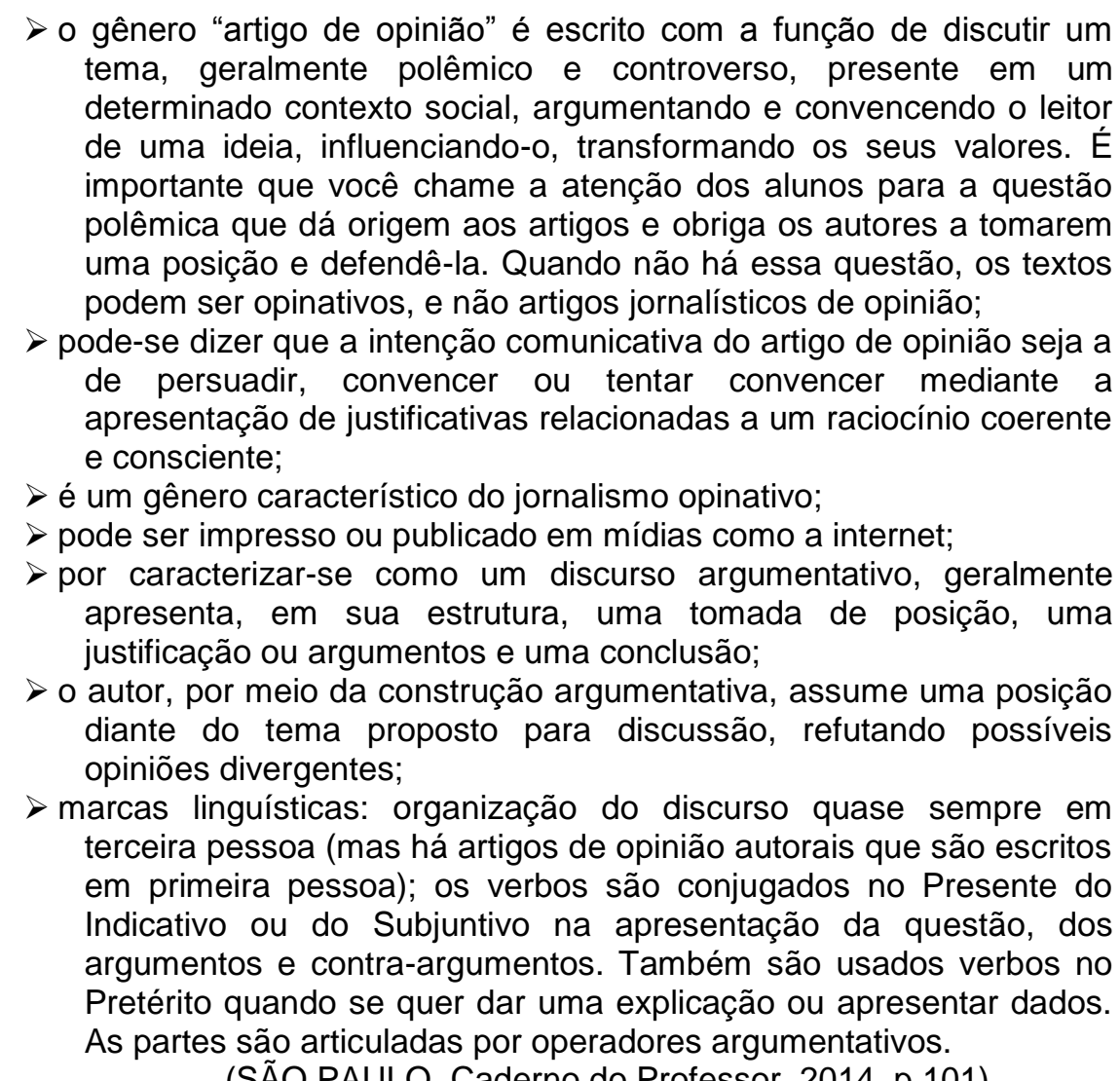

(SÃO PAULO, Caderno do Professor, 2014, p 101)

Para o aluno estabelecer um sentido para a argumentação nem sempre é tarefa fácil, pois o interlocutor ou é o professor ou é um interlocutor universal, abstrato, como no caso das avaliações externas realizadas na escola. Na proposta, muitas vezes, simula-se um contexto de produção que é fictício. Como decidir-se para quem escrever? Os autores do material ainda retomam que é necessário haver uma deliberação íntima e esta supõe uma contradição, sem a qual não há motivo para deliberar ou argumentar. Mobilizar o aluno a tomar essa atitude seria o primeiro passo para trabalhar efetivamente a argumentação. Ter vontade de conquistar a adesão do interlocutor é o principal motivo para o sujeito produzir seu texto. Pois,

Não basta falar ou escrever, cumpre ainda ser ouvido, ser lido. Não é pouco ter a atenção de alguém, ter uma larga audiência, ser admitido a tomar a palavra em certas circunstâncias, em certas assembleias, em certos meios. Não esqueçamos que ouvir alguém é mostrar-se disposto a aceitar-lhe eventualmente o ponto de vista.[...]

(PERELMAN \&OLBRECHTS-TYTECA,1996, p. 19) 
Todo discurso deve ser pensado em função de um auditório a ser alcançado, "É por essa razão que, em matéria de retórica, parece-nos preferível definir o auditório como o conjunto daqueles que o orador quer influenciar com sua argumentação. " (idem, p. 22) . A clareza do público a ser atingido é fundamental para elaboração do discurso argumentativo. Por isso que a entrada desse gênero na escola precisa estar vinculada a um contexto específico. Ao propor um artigo de opinião, para os alunos, seria interessante torná-lo funcional com a publicação em um jornal local, jornal escolar, site ou blog da escola. Enfim, trazer a esfera jornalística para a realidade do aluno.

Segundo essa concepção de argumentação, além de colocar o discurso argumentativo no gênero deliberativo, expande-se para o gênero epidítico, pois a emissão de valores e julgamentos estão presentes em todas as esferas. Não há neutralidade nem mesmo em um elogio, pois só há elogio segundo as concepções do sujeito e a aceitação do ouvinte. Essas premissas podem auxiliar na leitura expressiva de textos jornalísticos e publicitários e propiciar a tomada de posição nos textos argumentativos dos alunos.

Sabemos que, em sentido mais amplo, argumentar significa construir enunciados que convençam o interlocutor a concordar com determinado ponto de vista ou persuadi-lo a mudar um comportamento. Entretanto, em Carneiro (1993, p.34), podemos confirmar, em sentido mais restrito, que:

Argumentar é um processo que apresenta dois aspectos: o primeiro, ligado à razão, supõe ordenar ideias, justificá-las e relacioná-las; o segundo, referente à paixão, busca capturar o ouvinte, seduzi-lo e persuadi-lo. Assim, argumentar é uma operação delicada, já que é necessário construir ideias e não uma realidade.

Ainda, segundo esse autor, a argumentação no artigo de opinião compreende um quadro que se constitui pelo tema polêmico a ser debatido, por um argumentador que irá desenvolver um raciocínio a respeito do tema e um receptor, aquele que se pretende que compartilhe da mesma opinião do argumentador.

Os conceitos até agora abordados nos chamam a atenção para importância do contexto de produção, o que sabemos ser imprescindível à produção do artigo de opinião. Como foi visto na primeira proposta, esses fatores se constituem somente em um plano fictício, com o agravante de os alunos saberem que o texto se destina a uma avaliação e que seu interlocutor será somente o professor. 
No Guia de Produção textual da PUC do Rio Grande do Sul, encontramos algumas informações que serão válidas para entender melhor esse gênero e, certamente contribuíram à elaboração da sequência didática. Segundo esse Guia, "Num texto argumentativo, distinguem-se três componentes: a tese, os argumentos e as estratégias argumentativas". (PUC-RS, s/d)

A tese é a ideia sobre um tema polêmico que se pretende defender por meio dos argumentos, utilizando-se, para isso, estratégias argumentativas. Mas para que não se confunda estratégias com argumentos é necessária uma definição mais específica:

i) O argumento vem do Latim ARGUMENTUM, de ARGUERE, "tornar claro, demonstrar", de uma base Indo-Europeia ARG-, "brilhar, ser claro", a mesma que resultou no Latim ARGENTUM, "prata". E responde à pergunta por que, feita à tese.

ii) Já as estratégias são todos os recursos verbais e não-verbais que se utilizam para convencer, persuadir o interlocutor, tais como a clareza, uso de linguagem formal, título sugestivo/provocador, a organização dos argumentos, a contra-argumentação, o uso de perguntas retóricas, as figuras de linguagens, entre outras.

O Guia de Produção Textual da PUC do Rio Grande do Sul sugere a seguinte:

1. Proposição (tese): afirmativa suficientemente definida e limitada; não deve conter em si mesma nenhum argumento.

2. Análise da proposição ou tese: definição do sentido da proposição ou de alguns de seus termos, a fim de evitar mal-entendidos.

3. Formulação de argumentos: fatos, exemplos, dados estatísticos, testemunhos, etc.

4. Conclusão.

Quadro 2- Estrutura para a argumentação formal. Disponível em:

http://www.pucrs.br/gpt/argumentativo.php. Acesso em; 06/02/2014

Apesar de ser um conceito um tanto tradicional, é necessário confrontar as informações que podem estar ao alcance dos alunos - pois elas correspondem ao que geralmente é veiculado nos livros didáticos - com aquelas formuladas por estudiosos no assunto, pois o professor deve explorar as fontes às quais seus alunos têm acesso, para melhor orientar suas pesquisas. Sabemos que os textos reais, veiculados pelos meios jornalísticos nem sempre atendem a essa ordem canônica, mas também não se ignora que, para alcançar a autonomia na produção de um gênero é preciso dominar algumas de suas especificidades. Talvez por isso, 
encontremos em livros didáticos, sites educacionais e em outros veículos, "receitas" de como produzir determinado gênero. A grande questão é não se limitar a essas informações.

Outra caracterização que tomamos como base para compreender os aspectos constitutivos do artigo de opinião é aquela postulada por Boff, Köche e Marinello (2009)

\begin{abstract}
"Para a produção de um artigo de opinião, é necessário que haja um problema a ser discutido e seja proposta uma solução ou avaliação, refletindo a respeito do assunto. Assim, o artigo de opinião pode ser estruturado da seguinte forma: situação-problema, discussão e soluçãoavaliação. Vejamos:

a) situação-problema: coloca a questão a ser desenvolvida para guiar o leitor ao que virá nas demais partes do texto. Busca contextualizar o assunto a ser abordado, por meio de afirmações gerais e/ou específicas. Nesse momento, pode evidenciar o objetivo da argumentação que será sustentada ao longo do artigo, bem como a importância de se discutir o tema;

b) discussão: expõe os argumentos e constrói a opinião a respeito da questão examinada. Para Guedes, todo texto dissertativo precisa argumentar, ou seja, apresentar provas a favor da posição que assumiu e provas para mostrar que a posição contrária está equivocada. Os argumentos baseiam-se nos conceitos apresentados, na adequação dos fatos para exemplificar esses conceitos, bem como na correção do raciocínio que estabelece relações entre conceitos e fatos (2002, p. 313). Para evitar abstrações, geralmente faz uso da exposição de fatos concretos, dados e exemplos, com o emprego de sequências narrativas, descritivas e explicativas, entre outras;

c) solução-avaliação: evidencia a resposta à questão apresentada, podendo haver uma reafirmação da posição assumida ou uma apreciação do assunto abordado. Não é adequado um simples resumo ou mera paráfrase das afirmações anteriores.

Essa estrutura do artigo de opinião não é rígida, mas o caracteriza, diferenciando-o de outros gêneros, a fim de facilitar os encaminhamentos didáticos presentes no seu processo de ensino-aprendizagem. " (BOFF, KÖCHE E MARINELLO, 2009, pág 6)
\end{abstract}

Sintetizando o que foi abordado sobre o gênero artigo de opinião, destacamse os seguintes elementos: o artigo de opinião é um gênero discursivo que circula na esfera jornalística, mas não é necessariamente escrito por jornalistas; o autor procura, por meio da argumentação, convencer ou persuadir o seu interlocutor sobre sua posição em relação a um tema polêmico de interesse social; os argumentos precisam ser convincentes e consistentes; é necessária uma organização textual que permita dialogar com o interlocutor e com outras vozes sociais; o movimento argumentativo deve ter um encadeamento que leve à solução de um problema.

Os materiais utilizados em sala de aula, o livro didático Jornadas. Port-Editora Saraiva-9 ${ }^{\circ}$ ano e o sistema apostilado do Estado de São Paulo apresentam a definição de alguns tipos de argumentos, necessários à produção efetiva de artigos 
de opinião. Mas, considerando o que foi exposto até agora, nosso enfoque não será relativo à classificação dos tipos de argumentos e sim, ao uso de operadores argumentativos que colaborem com a argumentação discursiva.

O trabalho com a produção escrita envolve diversos aspectos; entretanto, como o gênero estará sendo apresentado pela primeira vez aos alunos, daremos ênfase à análise da construção da argumentação em três de suas produções, sabendo-se que a produção final aqui analisada, não expressará o resultado final da aprendizagem e sim uma etapa do processo.

Conhecer o gênero a ser trabalhado, fazer um levantamento teórico sobre produção textual, diagnosticar o conhecimento do aluno, preparar a SD, refletir sobre a ação pedagógica, tudo isso trará subsídios não só para esta pesquisa, mas para práticas futuras desta profissional e de outros que vierem a entrar em contato com o resultado deste trabalho. Os conhecimentos aqui adquiridos não estão somente direcionados ao aluno, mas também à melhoria de um contexto mais amplo da educação. A pesquisa profissional deve ser uma ferramenta para a formação continuada, ainda mais no segmento da educação, sujeito a constantes transformações. 


\section{CAPÍTULO 3 \\ CONTEXTO ESCOLAR DA PESQUISA}

A pesquisa sobre a produção de textos no ensino fundamental compreende a relação entre o linguístico e o extralinguístico, ou seja, é necessário considerar as condições econômicas, sociais, institucionais e culturais, condicionadoras da escrita dos estudantes. Os sujeitos-autores estão em uma sala de $9^{\circ}$ ano do Ensino Fundamental, pertencente à Escola Estadual Humberto Turner, localizada no Bairro do Itagaçaba, Município de Cruzeiro- Vale do Paraíba - interior do Estado de São Paulo. Hoje, com 82 anos, a escola passou por várias denominações desde a sua criação e, a partir de 1998, tornou-se Escola Estadual Humberto Turner.

O bairro do Itagaçaba está localizado na região periférica de Cruzeiro, sendo o único bairro situado na outra margem do Rio Paraíba do Sul, rio que atravessa o município e a região. Essa característica influenciou o caráter marginal dado aos seus primeiros habitantes e, posteriormente, a instalação do maior ponto de venda de drogas da cidade colaborou para que, até hoje, haja uma certa discriminação. Se, no início, o bairro era refúgio para classes sociais mais desfavorecidas, com a construção de uma segunda ponte, o acesso e a proximidade do centro estimularam a ocupação por comerciários e industriários. Hoje constitui-se em um bairro heterogêneo quanto ao aspecto socioeconômico. Possui um razoável comércio, duas escolas municipais, uma escola estadual, posto médico, igrejas evangélicas e católicas, algumas pequenas indústrias.

A escola EE Humberto Turner possui 15 salas de aula, sendo uma utilizada como laboratório de informática, uma cozinha, um galpão coberto, uma secretaria, uma sala de diretor, uma sala de vice-diretor, uma sala de coordenação pedagógica, uma sala de leitura, uma sala de professores, um almoxarifado, pátio, quadra de esportes coberta, espaço para refeitório, banheiros para alunos, banheiros para professores.

Na última década, a escola teve uma diminuição no número de alunos. Em 2002, havia 45 turmas distribuídas em três períodos. Hoje funcionam 9 turmas no período da manhã e 2 no período da tarde. Isso ocorreu devido à ampliação da rede 
municipal de ensino. Desde 2006, o sistema municipal absorveu, progressivamente, o segmento das séries finais do ensino fundamental

A Secretaria Estadual de Educação de São Paulo avalia o sistema de ensino, anualmente, por meio de uma avaliação externa: Sistema de Avaliação de Rendimento Escolar do Estado de São Paulo - o SARESP ${ }^{3}$. O resultado dessa avaliação é utilizado para gerar dados que norteiam as ações, tanto da escola quanto da rede estadual. Essa avaliação acontece no final do ano letivo e as séries

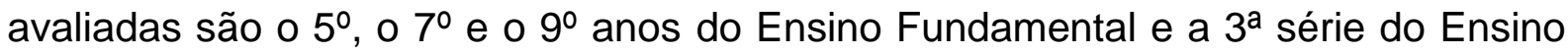
Médio.

A partir de 2007, a Secretaria Estadual lançou um programa de qualidade da escola e criou um índice para estabelecer metas para a melhoria do ensino em cada escola, o IDESP:

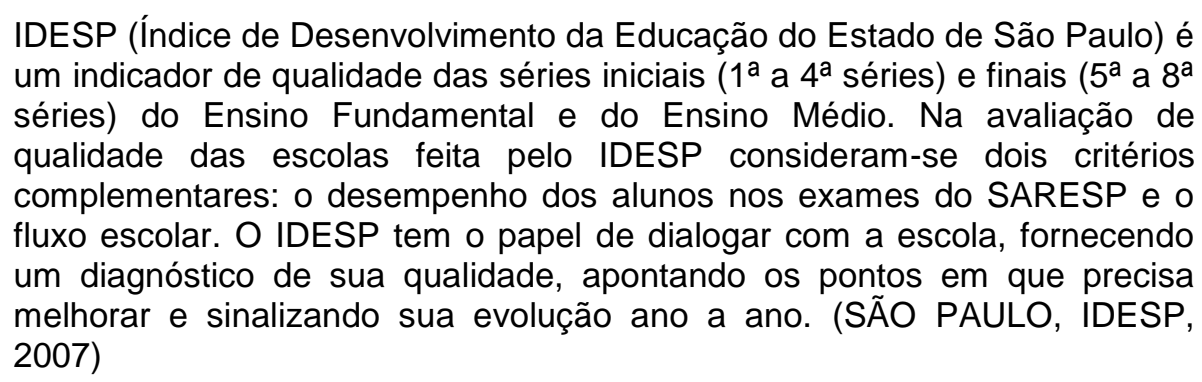

No início do ano seguinte à avaliação, é divulgado um boletim com os resultados da escola, uma análise dos níveis de desempenho, as metas atingidas e as projetadas para $\mathrm{o}$ ano seguinte. $\mathrm{O}$ documento também traz dados comparativos com a média do município, Diretoria de Ensino e Estado.

A EE Humberto Turner, desde 2009, vem sendo considerada uma escola prioritária, classificação dada pela Secretaria Estadual da Educação do Estado de São Paulo- SEE/SP- àquelas cujo IDESP está abaixo da média do Estado, Região ou Município. Uma das justificativas encontrada para esses índices, tanto no número de alunos quanto no desempenho, é que a partir de 2008, com a municipalização das séries finais do Ensino Fundamental, a ecola teve sua clientela

${ }^{3}$ Cf. Matrizes de Referência para a Avalição do SARESP. Disponível em: http://saresp.fde.sp.gov.br/2012/Arquivos/Saresp2012_MatrizRefAvaliacao_DocBasico_Com pleto.pdf 
modificada, pois há uma seleção na escola municipal do bairro, permanecendo nela os que têm melhor rendimento e cujos pais acompanham o desempenho do aluno. Reduziu-se, assim, o número de salas na escola estadual em questão, mas os alunos identificados com problemas de aprendizagem aumentaram em grandes proporções. Outra justificativa seria o alto índice de evasão, pois os alunos que não acompanham as expectativas tendem a abandonar a escola durante 0 ano. Isso acarreta o cálculo do Indicador de fluxo (índice de alunos que concluem o ano, excluindo-se os evadidos e retidos). O fluxo é um fator pelo qual é multiplicado o rendimento das avaliações externas. Quanto menor esse fator, menor o IDESP da escola.

Vejamos em números:

2011

\begin{tabular}{|l|l|l|l|l|l|}
\hline & \multicolumn{2}{|l|}{$\begin{array}{l}\text { Indicadores de } \\
\text { Desempenho de }\end{array}$} & $\begin{array}{l}\text { Indicador do } \\
\text { desempenho }\end{array}$ & $\begin{array}{l}\text { Indicador } \\
\text { fluxo }\end{array}$ & \\
\hline & $\begin{array}{l}\text { Língua } \\
\text { Portuguesa }\end{array}$ & Matemática & IDESP \\
\hline 9o ano & 1,5483 & 2,2620 & 1,91 & 0,7286 & 1,39 \\
\hline 3a série & 2,4167 & 1,5833 & 2,00 & 0,8009 & 1,60 \\
\hline
\end{tabular}

Quadro 03 - IDESP 2011- Boletim da Escola (SÃO PAULO, IDESP 2011)

\begin{tabular}{|l|l|l|}
\hline & 9 Ano EF & 3a série EM \\
\hline ESCOLA & 1,39 & 1,60 \\
\hline Diretoria & 2,42 & 1,89 \\
\hline Município & 2,25 & 1,65 \\
\hline Estado & 2,57 & 1,78 \\
\hline
\end{tabular}

Quadro 04 - IDESP 2011 - Resultados da Rede Estadual (SÃO PAULO, IDESP 2011)

\begin{tabular}{|c|c|c|c|c|c|}
\hline & \multicolumn{2}{|c|}{$\begin{array}{ll}\text { Indicadores } & \text { de } \\
\text { Desempenho } & \end{array}$} & \multirow[t]{2}{*}{$\begin{array}{ll}\text { Indicador } & \text { de } \\
\text { desempenho } & \end{array}$} & \multirow[t]{2}{*}{$\begin{array}{l}\text { Indicador de } \\
\text { fluxo }\end{array}$} & \multirow[t]{2}{*}{ IDESP } \\
\hline & $\begin{array}{l}\text { Língua } \\
\text { Portuguesa }\end{array}$ & Matematica & & & \\
\hline 9o- ano & 2,2017 & 2,0827 & 2,14 & 0,6777 & 1,45 \\
\hline 3a série & 2,4360 & 1,4737 & 1,95 & 0,8868 & 1,73 \\
\hline
\end{tabular}

Quadro 05 - IDESP 2012 - Boletim da Escola (SÃO PAULO, IDESP 2012)

\begin{tabular}{|l|l|l|}
\hline & 9 Ano EF & 3a série EM \\
\hline ESCOLA & 1,45 & 1,73 \\
\hline Diretoria & 2,34 & 1,88 \\
\hline Município & 2,14 & 1,81 \\
\hline Estado & 2,5 & 1,91 \\
\hline
\end{tabular}

Quadro 06 - IDESP 2011 - Resultados da Rede Estadual (SÃO PAULO, IDESP 2012) 


\begin{tabular}{|l|l|l|l|l|l|}
\hline & \multicolumn{2}{|l|}{$\begin{array}{l}\text { Indicadores de } \\
\text { Desempenho de }\end{array}$} & $\begin{array}{l}\text { Indicador de } \\
\text { desempenho }\end{array}$ & $\begin{array}{l}\text { Indicador } \\
\text { fluxo }\end{array}$ & \\
\hline & $\begin{array}{l}\text { Língua } \\
\text { Portuguesa }\end{array}$ & Matematica & & & \\
\hline 9o ano & 3,03 & 1,818 & 2,42 & 0,7921 & 1,92 \\
\hline 3a série & 2,517 & 1,3607 & 1,94 & 0,8168 & 1,52 \\
\hline
\end{tabular}

Quadro 07 - IDESP 2013- Boletim da Escola (SÃO PAULO, IDESP 2013)

\begin{tabular}{|l|l|l|}
\hline & 9 Ano EF & 3a série EM \\
\hline ESCOLA & 1,92 & 1,58 \\
\hline Diretoria & 2,41 & 1,83 \\
\hline Município & 2,14 & 1,78 \\
\hline Estado & 2,50 & 1,83 \\
\hline
\end{tabular}

Como vemos nas tabelas acima, o índice de desempenho em Língua Portuguesa tende a ser melhorado na $3^{\underline{a}}$ série do Ensino Médio. Entretanto, devemos considerar que não são os mesmos alunos, as mesmas turmas, pois a cada ano são avaliados os alunos que estão naquelas séries e, muitas vezes, 0 professor não pode acompanhar uma turma em seu percurso. Percebemos também, que o fluxo é um fator determinante para o cálculo do IDESP e os números da escola são preocupantes. Mesmo com várias ações da gestão escolar, dada a característica da comunidade, a evasão é uma constante na realidade da escola.

A sala analisada nesta pesquisa está inserida nesse contexto e possui características peculiares: dos 37 alunos matriculados 04 deixaram de frequentar, 08 comparecem esporadicamente e os demais se ausentam sistematicamente, ou seja, temos uma média de 19 a 20 alunos presentes por dia, embora nem sempre sejam os mesmos.

Para obtermos mais informações sobre a turma, foi aplicado um questionário socioeconômico, cujos dados mais relevantes passamos a apresentar:

Tabela 01 - Ocupação profissional dos membros da família Ocupação Quantidade de membros

\begin{tabular}{ll} 
Indústria & 02 \\
\hline Comércio & 05 \\
\hline Doméstica & 07 \\
\hline Autônomo & 6 \\
\hline Não quiseram informar & 6 \\
\hline
\end{tabular}


Tabela 02 Escolaridade (pais e mães)

\begin{tabular}{ll}
\hline Grau de escolaridade & Número \\
\hline Ensino Superior & 01 (pai) \\
Ensino Médio Completo & 05 (3 pais e 2 mães) \\
Ensino Fundamental Completo & 03 \\
Ensino Fundamental Incompleto & 14 (maioria mães) \\
\hline
\end{tabular}

Tabela 03 - Número de membros que residem com o aluno

\begin{tabular}{ll}
\hline Membros por domicílio & Quantidade de alunos nessa situação \\
\hline 02 & 01 \\
03 & 02 \\
04 & 03 \\
05 & 02 \\
06 & 05 \\
Mais de 6 pessoas & 06 \\
\hline
\end{tabular}

Verificamos que as famílias são compostas, em sua maioria, de cinco membros ou mais. Entre os alunos pesquisados, poucos são aqueles cujos pais possuem ensino médio completo e somente um pai concluiu o Ensino Superior. Cerca de $40 \%$ das famílias recebem bolsa família ou outro benefício do governo. A ocupação profissional está centrada nos serviços autônomos (pedreiro, servente, pintor etc.) e serviço doméstico.

Um dado curioso é que alguns alunos não sabiam ou não poderiam informar de onde provinha o sustento da família. Sabendo-se da realidade da comunidade, deduz-se que as atividades relacionadas ao tráfico estão presentes em muitos domicílios.

A maioria declarou morar em imóvel próprio da família, com uma média de 5 cômodos por residência; sendo que quase a totalidade das casas tem acabamento, com piso, laje, telhado etc.

Entre os alunos pesquisados 4 informaram que olham irmãos mais novos após a escola, 6 ajudam nas atividades domésticas e os demais não realizam outras atividades específicas ou não quiseram informar.

Quanto ao número de livros que possuem em casa, excetuando-se os didáticos, somente em 7 residências há livros ou revistas e, na maioria, há uma ou mais bíblias.

Esses dados permitiram relacionar determinados comportamentos em classe ao contexto familiar. Observamos que os alunos com mais dificuldades de aprendizagem são aqueles cuja escolaridade familiar não atinge $o$ ensino 
fundamental completo. Os alunos que declararam receber benefícios governamentais (bolsa família, bolsa escola etc.) são os mais frequentes, porém os menos comprometidos. Os mais participativos estão no grupo dos pais que têm o ensino médio completo ou superior.

Conforme Soares (2004), o letramento envolve o uso da leitura e da escrita em práticas sociais, não só na escola. Se o aluno não é exposto a situações letradas fora da escola, se a presença de materiais de leitura é escassa no ambiente familiar, se os familiares participam pouco da cultura letrada, é provável que o desencontro desse estudante com as situações de leitura e escrita, promovidas pela escola, seja ainda maior. Pensamos que, quanto maior for a exposição a eventos de letramento fora da escola, cuja definição encontramos em Kleiman (2005, p.23) "Ocasião em que a fala se organiza ao redor de textos escritos e livros, envolvendo a sua compreensão...", maior será a identidade do aluno com os textos apresentados pela escola.

Considerando o aspecto dialógico da teoria bakthinina, na qual "cada enunciado é um elo da cadeia muito complexa de outros enunciados", observamos que o conhecimento do letramento extraescolar dos estudantes é fundamental para o planejamento e a execução de um trabalho docente, promotor de um avanço efetivo no letramento dos estudantes.

Essa pesquisa deveria estar presente na rotina das escolas, no início de cada ano, pois assim permitiria um planejamento das aulas mais adequado às necessidades de cada turma.

\subsection{CONSIDERAÇÕES SOBRE O CURRÍCULO DO ESTADO DE SÃO PAULO}

O Currículo do Estado de São Paulo foi consolidado desde 2008 e constitui-se em um documento com textos-base para outros documentos: caderno do gestor, caderno do professor, caderno do aluno e as matrizes de referência para avaliação do Sistema de Rendimento Escolar do Estado de São Paulo (Saresp). As orientações sugeridas, nesses documentos, abrangem um contingente de, segundo dados do censo 2013, 1.668 .868 alunos no Ensino Fundamental e 1.575 .897 no Ensino Médio. No Saresp 2013, foram avaliados 410.971 alunos que cursavam o 9o 
ano do Ensino Fundamental. Sendo assim, as orientações abordadas nos documentos oficiais são dirigidas para um público genérico e cabe às escolas elaborar suas propostas pedagógicas de acordo com as especificidades de cada escola e/ou turma. Todavia o material deixa margem para uma interpretação mais autoritária, trazendo em seu discurso instruções específicas quanto à metodologia a ser utilizada para o desenvolvimento das ações.

No Ensino Fundamental, a organização metodológica segue algumas premissas:

- Em todas as séries, no $1^{\circ}$ bimestre, o eixo principal é o estudo de um agrupamento tipológico (narrar, expor, descrever ações e argumentar,

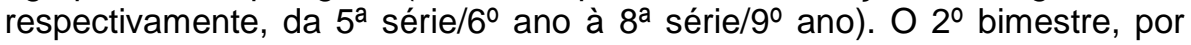
sua vez, é organizado em torno do estudo de gêneros textuais que apresentem, predominantemente, o agrupamento tipológico estudado no bimestre anterior. Já nos 3ํㅜ e 4ํㅡㄹ bimestres desenvolve-se, em cada um, um projeto, que engloba a tipologia e os gêneros estudados, inserindo-os em uma perspectiva discursiva. Essa opção metodológica pareceu-nos articular três aspectos fundamentais nos estudos de língua contemporâneos: os agrupamentos tipológicos, os gêneros e o discurso.

- Em todos os bimestres, são apresentadas, em média, cinco Situações de aprendizagem. Desse modo, para o estudo da tipologia argumentativa, no $1^{\circ}$ bimestre da $8^{\text {a }}$ série/9o ano, são apresentadas cinco Situações de Aprendizagem; para $\circ 2^{\circ}$. bimestre, com o objetivo de estudar gêneros como o texto de opinião, são apresentadas mais cinco; e assim sucessivamente. Cada uma das Situações pode ser compreendida como uma proposta de sequência didática, com outras sugestões de encaminhamento no Caderno do Professor.

- Em cada Situação de Aprendizagem são desenvolvidos, em concomitância com o estudo tipológico, de gênero ou de discurso, dois aspectos: a) Estudo de conteúdos: em todas as sequências didáticas, há conteúdos específicos sendo trabalhados (características de um gênero ou tipologia, aspectos gramaticais etc.).

Eles são os temas comuns de estudo linguístico, vistos em uma perspectiva de variedades linguísticas, associados a questões de gêneros, tipologia ou qualquer outro conteúdo necessário ao desenvolvimento de habilidades leitoras (a intertextualidade, por exemplo), escritoras (a coesão e a coerência, por exemplo) e de oralidade (estudo de gêneros orais, como apresentações ou debates, entre outros)

b) Desenvolvimento de habilidades centradas em quatro grandes competências: escritora, de leitura, de habilidades orais, linguística. Cada situação, no Caderno do Professor, começa com um quadro, que indica os conteúdos e as habilidades que serão desenvolvidos. No texto do Caderno do Professor propriamente dito, encontra-se uma sequência didática, já organizada de forma a contemplar as quatro competências mencionadas. Isso está marcado no texto com expressões como "para o desenvolvimento de habilidades de leitura...".

(São Paulo, 2010, p. 39)

O currículo está pautado nas mais recentes teorias linguísticas, trazendo conceitos da linguística textual, análise do discurso e apoia-se nas teorias de Bakhtin, Marcuschi, Orlandi, Koch, entre outros. 
Em sua apresentação traz conceitos de termos da área para orientar os docentes no estudo e implementação do currículo. Resumidamente, relacionamos aqueles que serão analisados neste trabalho.

\begin{tabular}{|l|l|}
\hline TIPO & $\begin{array}{l}\text { Composição linguística que organiza - pela sua predominância } \\
\text { em um texto - os diferentes gêneros textuais. }\end{array}$ \\
\hline GÊNERO & $\begin{array}{l}\text { Evento linguístico social que organiza os textos a partir de } \\
\text { características sociossemióticas: conteúdos, propriedades } \\
\text { funcionais, estilo e composição estrutural. }\end{array}$ \\
\hline TEXTO & $\begin{array}{l}\text { Totalidade semiótica de sentido constituída por uma } \\
\text { combinação de linguagens e operações aplicadas ao fluxo de } \\
\text { uma produção semiótica concreta. }\end{array}$ \\
\hline ENUNCIAÇÃO & $\begin{array}{l}\text { Ato ou acontecimento pelo qual um indivíduo empírico, por } \\
\text { meio de trabalho físico e mental, produz um enunciado que será } \\
\text { recebido, em processo interativo e social, por outro indivíduo. } \\
\text { Esse acontecimento instaura um "eu" que, dentro do enunciado, } \\
\text { assume a responsabilidade do ato de linguagem e um "você" } \\
\text { constituído pelo "eu" (enunciador) do texto. }\end{array}$ \\
\hline DISCURSO & $\begin{array}{l}\text { Produto de uma enunciação composto de todos os elementos } \\
\text { que concorrem ao processo de significação, superando a } \\
\text { somatória das partes. O discurso esquematiza as experiências a } \\
\text { fim de torná-las significantes e compartilháveis. }\end{array}$ \\
\hline
\end{tabular}

Quadro 09 - Conceitos adotados pelo Currículo do Estado de São Paulo (São Paulo, 2010, p. 34)

Apesar de muitas escolas tomarem os cadernos do professor e do aluno como apostilas a serem seguidas, cada escola tem uma certa autonomia para organizar-se de forma a implementar o currículo da melhor maneira possível. Entretanto não podemos deixar de lembrar que as avaliações externas são pautadas nas habilidades e competências previstas nas Matrizes de Referência e essas estão contempladas nos materiais de apoio (apostila) do professor e do aluno. As sequências didáticas sugeridas nesses materiais podem ser, no nosso entendimento, substituídas por outras, desde que atendam aos objetivos propostos para a série.

Além da avaliação do Saresp, a Secretaria Estadual de Educação promove, desde 2012, outro tipo de avaliação externa, a Avaliação em Processo. Nela há uma prova de língua portuguesa, na qual se verificam as habilidades de leitura e uma 
prova de produção textual. Essa avaliação acontece no início de cada semestre. $\mathrm{Na}$

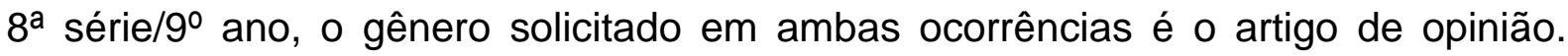
Tendo em vista o currículo e as matrizes de referência para o Saresp, pode-se avaliar o desenvolvimento da aprendizagem durante o processo.

A caracterização dos contextos escolar, familiar e curricular foi fundamental para compreender a realidade dos estudantes e do sistema escolar no qual estão inseridos. Em primeiro lugar, observamos que a unidade educacional em análise, vive uma certa concorrência com a escola municipal do bairro que busca captar os melhores estudantes, deixando os demais para a instituição estadual. Esta escola se localiza em um bairro periférico, que se encontra em processo de desenvolvimento, com a valorização imobiliária, a expansão do comércio e a chegada de moradores com melhor poder aquisitivo. Todos esses elementos levariam a crer que a escola receberia alunos com um perfil socioeconômico diferente, mas não é o que ocorre. Os pais preferem matricular seus filhos ou na escola municipal do bairro ou nas escolas centrais da cidade. Verifica-se, portanto, que a comunidade discrimina e reforça o estigma da escola, apesar desta ter conseguido bom desempenho em provas do Enem e do Saresp ao longo dos anos. Em seguida, por meio do questionário aplicado, constatamos que os estudantes provêm de um meio familiar com baixo letramento e que se sustenta, em boa parte, por meio dos benefícios governamentais (bolsa escola e bolsa família); esses programas garantem a frequência dos estudantes em condição socioeconômica mais desfavorável. É preciso salientar que a baixa frequência dos demais estudantes não parece se constituir em um problema para os pais, que não se importam com as faltas constantes de seus filhos. Por fim, as orientações curriculares são amplas e necessitam de uma adaptação às realidades social, regional, econômica e cultural dos estudantes. Os conteúdos previstos no currículo e materializados no "caderno do aluno" precisam de uma reflexão sobre a sua eficácia no processo de ensinoaprendizagem, desafio que esta pesquisa busca enfrentar.

Pretendemos esclarecer que a contextualização da escola e a relação dessa com o currículo do Estado de São Paulo não têm aqui pretensão de justificar os possíveis fracassos da escola pública, mas antes traçar o contexto em que está inserido o objeto desta pesquisa. Diante de milhares de alunos, encontram-se 
professores como essa pesquisadora que procuram se organizar de forma a aplicar as novas teorias de aprendizagem da língua em suas salas de aula. O contexto socioeconômico e cultural, muitas vezes, desfavorece as práticas pedagógicas; porém pequenos avanços devem ser considerados no processo da melhoria da educação. 


\section{CAPÍTULO 4 \\ DESCRIÇÃO, JUSTIFICAÇÃO E ANÁLISE DO TRABALHO COM AS CARTAS DE RECLAMAÇÃO}

Neste capítulo, apresentaremos o resultado da primeira produção, os encaminhamentos após a análise desse resultado, assim como a descrição e a justificativa da escolha de se trabalhar com a carta de reclamação para dar início ao processo de aprendizagem da argumentação.

\section{1-RESULTADOS DA AAP (AVALIAÇÃO DA APRENDIZAGEM EM PROCESSO)}

A primeira produção escrita (AAP) nos mostrou que os alunos apresentavam muita dificuldade em expor sua opinião: não assumiram, na sua maioria, uma posição em relação ao assunto e não organizaram seus textos de forma a reconhecermos um gênero do discurso, pois, para termos um gênero na perspectiva bakthiniana, é preciso reconhecer algumas características relativamente estáveis em textos que circulam em uma esfera de comunicação social.

Retomando a proposta descrita no capítulo 2, temos as seguintes orientações:

ETAPA IV

Agora é a sua vez!

Você leu um texto que fala dos perigos de empinar pipa utilizando cerol e outro que ensina como confeccionar pipas. Também realizou outras leituras, orientadas pelo professor. Após a realização das atividades propostas, elabore um texto de opinião, cujo tema é: Os benefícios e os males de se empinar pipa.

Lembre-se de utilizar argumentos a favor ou contra empinar pipa nos dias de hoje, deixando claro o que você pensa a respeito.

Recomendações:

1. Faça um rascunho. 
2. Verifique se o leitor de seu texto compreenderá o que escreveu.

3. Passe o rascunho a limpo, utilizando caneta azul ou preta.

4. Capriche na letra!

5. Não se esqueça do título.

6. Utilize uma folha de caderno para a produção textual.

Quadro 10 - AAP-Produção Textual- $9^{0}$ ano do EF- $6^{\mathrm{a}}$ edição p.:4.

Como percebemos, a proposta não deixa claro em qual gênero o aluno deverá escrever; sugere que ele escreva um texto de opinião. Nas recomendações pedagógicas, documento dirigido ao professor, há referência ao agrupamento sugerido por Dolz e Schneuwly (2004 no Quadro 1: Proposta provisória de agrupamento de gêneros, p. 51 e 52.

\begin{tabular}{|c|c|}
\hline $\begin{array}{l}\text { Dominios sociais de comunicação } \\
\text { Aspectos tipológicos } \\
\text { Capacidades de linguagem dominantes }\end{array}$ & Exemplos de gêneros orais e escritos \\
\hline $\begin{array}{c}\text { Discussão de problemas sociais controversos } \\
\text { Argumentar } \\
\text { Sustentação, refutação e negociação } \\
\text { de tomadas de posição }\end{array}$ & $\begin{array}{l}\text { textos de opinião } \\
\text { diálogo argumentativo } \\
\text { carta de leitor } \\
\text { carta de reclamação } \\
\text { carta de solicitação } \\
\text { deliberação informal } \\
\text { debate regrado } \\
\text { assembleia } \\
\text { discurso de defesa (advocacia) } \\
\text { discurso de acusação (advocacia) } \\
\text { resenha crítica } \\
\text { artigos de opinião ou assinados } \\
\text { editorial } \\
\text { ensaio } \\
\text {... }\end{array}$ \\
\hline
\end{tabular}

Figura 07 - Quadro 1- Agrupamentos de Gêneros DOLZ e SCHNEUWLY (2004, p.51-52)

Mesmo assim, sabemos que essa classificação é insuficiente para identificar e produzir um gênero do discurso, pois essa designação não se concretiza nas situações reais. Com essas características tipológicas, podemos encontrar comentários em revistas, em sites e em outras mídias, artigos assinados em revista ou jornal, entre outros gêneros, mas um texto de opinião, com tal nomenclatura, não é comum encontrar. Isso prejudicou em demasiado o trabalho, tanto do professor, quanto do aluno.

Vale ainda ressaltar que, embora na proposta fique subtendido que 0 professor realizou outras leituras, isso não foi possível, pois o material foi entregue no dia da aplicação das provas e o tempo previsto não poderia ultrapassar a 
duração de duas aulas. Além disso, supõe-se que o aluno já saiba utilizar a argumentação, mesmo que, em nenhum caderno das séries anteriores, esse assunto tenha sido abordado.

No total foram avaliados 26 textos, dos quais 5 se posicionaram e argumentaram sobre o tema (Tipo A), 12 produziram uma sequência de malefícios e benefícios (Tipo B), 3 aconselharam o interlocutor na prática da brincadeira (Tipo C) e 6 copiaram trechos do texto de apoio (Tipo D).

A seguir, reproduziremos exemplos dos quatro tipos de agrupamento; lembrando que, somente os aspectos ortográficos sofreram correções, mas os demais foram mantidos para não interferirem nos aspectos discursivos.

Tipo A

\section{Soltar pipa com segurança}

Pra mim a pipa não traz nenhum benefício, mas eu vejo pros meus amigos que pra eles a pipa traz diversão e alegria.

Eu não gosto de pipa, porque quando os meninos põem cerol pode prejudicar, causa até a morte. As pipas são um risco para os motociclistas e pessoas que estão andando na rua. A culpa pode ser até de quem está soltando a pipa. Nas férias é época comum de ver crianças e adolescentes empinando a pipa e arriscando a vida para correr atrás delas.

Se você gosta de pipa não use cerol na linha. É a melhor forma de brincar sem arriscar a vida das pessoas e a sua.

No Brasil eu já vi em jornal e revistas mais de 3 mil pessoas morrendo, por causa da pipa. Quando a pipa enrosca no fio e eles tentam pegar e acabam levando um choque muito grande. Só acho que essa lei que saiu contra o cerol não está adiantando nada tinha que melhorar.

Aluna G.M

Percebemos que a aluna procurou atender à proposta, posicionando-se contra o uso do cerol nas pipas e, também, demonstrando que não aprova a brincadeira. Fez uma tentativa de contra argumentação no terceiro parágrafo. Como não havia um interlocutor definido, tanto a adequação linguística como a movimentação argumentativa ficaram prejudicadas. "A quem devo convencer? ", pergunta essa que não foi respondida pela proposta. Como nos lembra Perelmam\&Olbrechts- Tyteca (1996): 
Para que haja argumentação, é mister que, num dado momento, realize-se uma comunidade efetiva dos espíritos. É mister que se esteja de acordo, antes de mais nada e em princípio, sobre a formação dessa comunidade intelectual e, depois, sobre o fato de se debater uma questão determinada. Ora, isso não é de modo algum evidente.

(Perelman \&Olbrechts-Tyteca, 1996,p.16)

\section{Tipo B}

O que a pipa traz

A pipa em si traz muitos benefícios e males de se empinar a pipa.

Benefícios que a pipa traz: Os benefícios que a pipa traz para nós, é a diversão de empinar e de soltar, brincadeiras entre amigos e se divertir, mas sem o uso do cortante porque é proibido.

Males que traz a pipa: A pipa traz riscos em cortar o pescoço, cortar o dedo, e pode prejudicar os ciclistas e os motociclistas, os motociclistas que não usam a antena podem sair prejudicados, com o pescoço cortado, braços, e outras partes do corpo, podem até matar, por isso tome muito cuidado.

Aluno P. H.

Não conhecendo o gênero, esse e outros 11 alunos procuraram responder à proposta de forma literal. Optaram por fazer uma lista de benefícios e malefícios conforme sugerido nas orientações. Como desconheciam ou não tinham prática no exercício da argumentação, elencaram os benefícios da brincadeira e os riscos sugeridos no texto de apoio. Percebe-se que o aluno teve dificuldade de tomar uma posição a respeito do assunto.

\section{Tipo C}

Os benefícios e os males de se empinar pipas

Quem falou que não pode soltar pipas? Apesar dos perigos que as pipas tem você tem que soltar longe de fios e postes e não solte com cerol, isso é uma brincadeira muito divertida, mas...brincar perto da rede elétrica pode ser um perigo.

Então por isso que você nunca pode soltar pipas perto de fios e postes Você mesmo(a) pode se machucar 
Nunca arrisque sua vida por causa de uma pipa. As consequências que irá passar com as pipas é muito sério.

Aluna S. R.

A aluna demonstra pouco domínio das convenções da escrita. Entretanto as inadequações quanto à pontuação não prejudicam a coesão e coerência do texto. Outro aspecto a ser destacado é a escolha da tipologia. Talvez influenciada pelo texto de apoio, optou por uma sequência injuntiva, prescritiva, marcada pelo uso do imperativo, da segunda pessoa do singular e o tom de aconselhamento.

Tipo D

Os benefícios bom= distrair a mente é divertido atrai os amigos é uma brincadeira legal é legal fazer pipa, corta as outras pipas.

Os malefícios ruim = As pipas são um risco para os motociclistas e representa perigo até para quem não participa da brinkadeira. Por exemplo, pessoas que se utilizam de moto para se locomover estão expostas a ameaça da linha com cerol. Na época das férias é comum ver crianças e adultos empinando pipa e arriscando a vida para correr atrás delas.

Aluna J.C.

Essa aluna tem mais dificuldade na compreensão da proposta; percebe-se que acrescentou a explicação dos termos benefícios e malefícios comentados na sala, ou seja, incluiu as palavras "bom" e "ruim", respectivamente, aos itens mencionados no tema da proposta de produção. Demonstra, também, pouco domínio da norma escrita, pois no único período de sua autoria elenca os benefícios sem fazer uso da pontuação adequada. O segundo parágrafo (em destaque) constitui-se, em sua totalidade, cópia do texto de apoio, com exceção da grafia da palavra "brinkadeira", que no texto original está de acordo com as normas ortográficas.

Essa breve análise nos mostra que o trabalho com a produção de textos requer uma cuidadosa atenção na elaboração das propostas de produção. Além disso, proporciona um panorama das dificuldades encontradas pelos alunos na composição do texto escrito. 


\subsection{TRABALHANDO COM CARTAS ARGUMENTATIVAS- UMA APROXIMAÇÃO DO GÊNERO}

Como o material do Estado apresentava uma série de textos de diversos gêneros, sem unidade temática e de tipologias diferentes, se iniciássemos por esse material, dada a situação apresentada, levaríamos muito tempo para que os alunos percebessem que as especificidades de um texto o constituíam como gênero. Além disso, a maioria dos textos (trechos) não fazia parte do uso cotidiano dos alunos.

Desde que foi instituído o Currículo do Estado de São Paulo, muitas escolas exigem que o professor siga exatamente a apostila, independentemente do contexto da escola e das necessidades do aluno. Como a proposta pedagógica da nossa escola nos permite fazer adequações curriculares, achamos por bem iniciarmos uma sequência de atividades que permitisse ao aluno uma expressão mais espontânea e, ao mesmo tempo, o introduzisse na prática dos gêneros argumentativos. No currículo está previsto o estudo de carta do leitor (Situação de aprendizagem 6). Partimos do pressuposto de que os alunos já conhecem esse gênero, pois a carta familiar é um gênero trabalhado desde as primeiras séries do ensino fundamental, e do fato desse gênero ser precedente de muitos outros, inclusive dos artigos de opinião, conforme Bazerman (2011), estando próximo dos gêneros primários, conforme a concepção de Bakthin (2003), resolvemos trabalhar o gênero carta de reclamação para dar início ao processo de argumentação, necessário à posterior aprendizagem do gênero artigo de opinião.

Segundo Koche, Boff e Marinello (2010), a carta de reclamação é um desdobramento do gênero carta argumentativa, pois nele o emissor se dirige a um receptor específico para reclamar, solicitar algo ou emitir uma opinião.

A carta foi um dos primeiros gêneros escritos que surgiram na história. Bazerman (2011) fez um estudo no qual aponta a carta como gênero basilar de outros gêneros que circularam e ainda circulam na sociedade. As primeiras cartas, segundo o autor, eram coletivas e tinham o objetivo de ordenar ou proclamar alguma determinação das autoridades. Na Grécia antiga, os mensageiros levavam a 
correspondência e as liam, representando assim o emissor. Muitas vezes, complementavam, oralmente, o conteúdo do texto.

Aos poucos, essas cartas tornaram-se mais pessoais, adquirindo caráter particular, muito comum no período helênico e romano. Nessa época, as cartas já eram utilizadas para fazer petição e recomendação, gêneros que circulam até hoje nas transações sociais.

Segundo o autor, as composições comerciais e as correspondências pessoais modernas guardam alguns resquícios das primeiras cartas; seja em um email, em um talão de cheque, requerimentos, circulares, enfim, em vários gêneros podemos perceber características da carta.

Acreditando que o gênero fosse o mais próximo dos saberes dos alunos, ele foi selecionado para iniciar o trabalho com a argumentação. Escolhido o gênero, passamos a outras questões mais específicas, como veremos adiante.

Sabendo da realidade da sala, em relação aos seus conhecimentos linguísticos, procuramos elaborar uma sequência de atividades, dentro do módulo, de forma que o conteúdo não fosse um empecilho para que escrevessem os seus respectivos textos. A proposta consistia em que eles identificassem um problema de ordem pública no bairro ou na rua onde moram. A partir da discussão, eles produziriam uma carta de reclamação, endereçada a um setor da administração pública, reclamando ou solicitando um serviço a ser realizado no bairro. A seguir, passaremos à descrição da sequência.

\subsubsection{SEQUÊNCIA DIDÁTICA- CARTA}

Resumidamente, a sequência foi organizada do seguinte modo:

Atividade 1- Apresentação/Contextualização da situação

Atividade 2 - Produção inicial

Atividade 3 - Leitura de cartas argumentativas sobre questões do cotidiano

Atividade 4 - Leitura de trecho de texto do Direito Constitucional

Atividade 5 - Correção coletiva - oral

Atividade 6 - Reescrita 


\subsubsection{DESCRIÇÃO DA METODOLOGIA DE SALA DE AULA PARA SEQUÊNCIA DA CARTA}

As aulas dessa turma são compostas por seis aulas semanais, sendo que duas intercaladas na segunda-feira, uma na terça, duas intercaladas na quarta e outra na quinta. Assim, as atividades foram programadas para que pudessem ser realizadas durante essas aulas e algumas, para que pudessem ser interrompidas nos dias de aulas duplas.

Foi combinado com a coordenadora pedagógica para que a mesma filmasse e acompanhasse a aula; assim iniciamos a primeira aula- atividade 1- com cada aluno sentado em seu lugar. Perguntei-Ihes se havia algum problema relacionado à rua, ao bairro ou à cidade, que eles gostariam de resolver. Nesse momento, houve uma boa participação da turma e fui anotando no quadro cada sugestão apontada por eles: calçamento das ruas, limpeza das ruas da cidade, erosão em uma parte do bairro, manutenção dos semáforos (no caso deles, trata-se de um especificamente, pois controla o fluxo na ponte que liga o bairro ao centro), falta de remédios nos Postos de Saúde e atendimento médico, tanto no Posto de Saúde do bairro, quanto no pronto-socorro do centro da cidade.

Após as sugestões, questionei-os: se fosse possível entrar em contato com os setores, quais meios seriam eficazes? Alguns sugeriram ir a um jornal, ou à rádio da cidade; outros sugeriram uma manifestação pública, ir à Câmara Municipal etc. Em seguida a essas sugestões, perguntei se uma carta não seria uma boa forma de deixar registrada a nossa reclamação. Houve consenso afirmativo.

Antes de começarmos as atividades, expus a proposta da produção textual. Deixei claro que só enviaríamos a carta, se o remetente assim o quisesse, o que seria feito após o desenvolvimento das atividades e da revisão final. Desta maneira, passei a questioná-los sobre quem seriam os destinatários de suas cartas, pois, como se trata de uma repartição pública relativamente grande, precisaríamos encaminhar a um setor específico. Passamos a reler os problemas e decidir a qual secretaria endereçar a carta. Eles conheciam apenas algumas secretarias, como a Secretaria de Obras e a de Saúde. As demais foram colocadas, no quadro, para eles anotarem junto ao problema apontado. 
$\mathrm{Na}$ aula seguinte, no mesmo dia, propus que escrevessem a primeira versão da carta - Atividade 2. Para isso, relembramos a macroestrutura: Local e data, saudação, corpo do texto e despedida. Fiz o seguinte esboço no quadro antes que eles começassem a escrever.

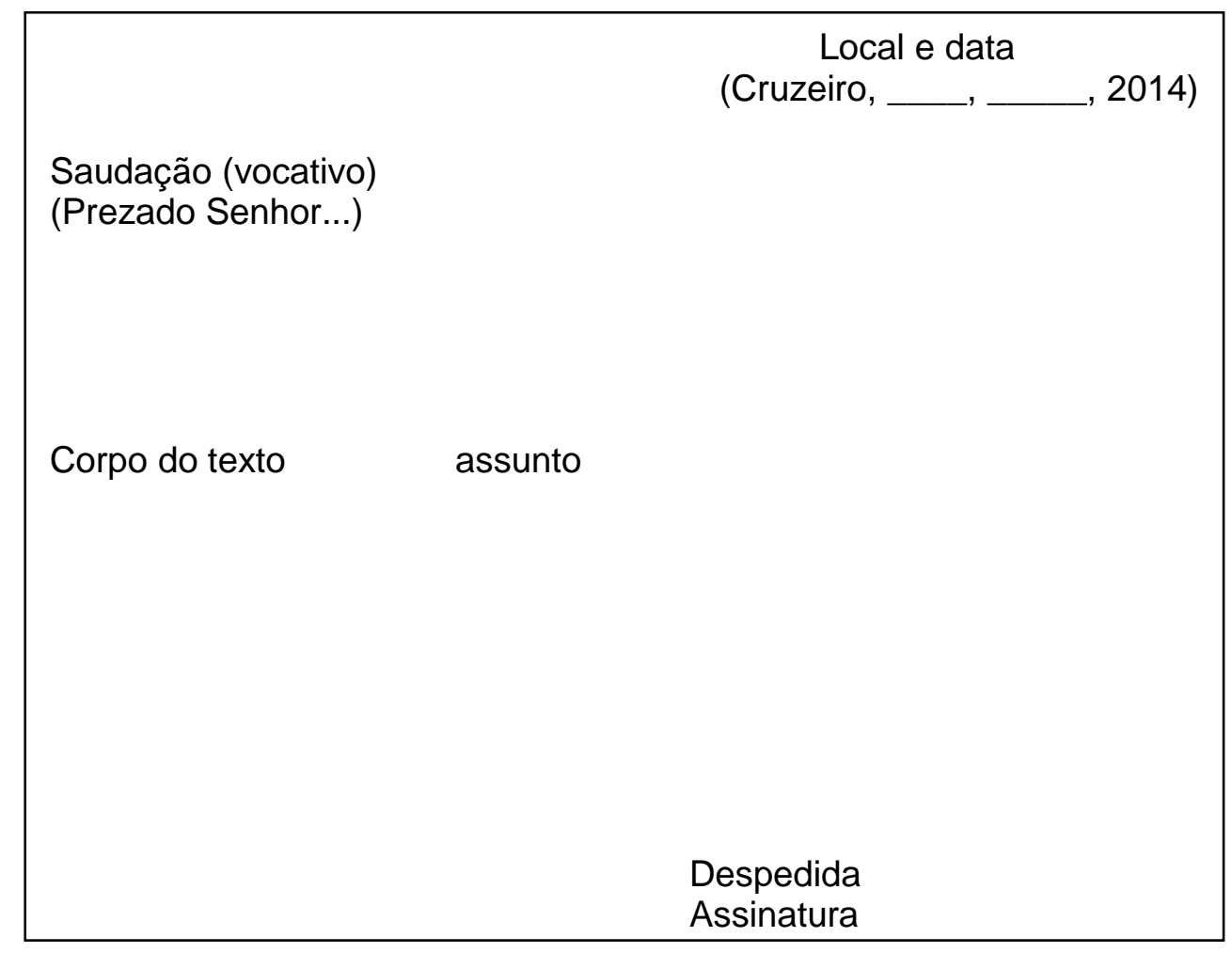

Após a leitura dos resultados da produção, além de uma releitura nas proposições de Dolz e Schneuwly (2004), percebi que, antes dessa primeira produção, deveríamos ter lido outros textos do gênero, ter proposto atividades que permitissem que reconhecessem ou relembrassem as especificidades discursivas e não somente 0 aspecto estrutural como foi feito. Com essa preparação, provavelmente os resultados seriam outros.

Antes de passar para atividade 3 , em uma tentativa frustrada, tentei que lessem uma carta e comparassem com a deles para identificarem os elementos que compunham o gênero. Somente após uma reflexão e com um olhar mais distante do objeto de análise, percebi que a falha consistiu na ausência de subsídios dados aos alunos para que desenvolvessem a atividade. Por achar que o gênero era comum a todos, pressupus que não teriam problemas ao fazer a atividade.

$\mathrm{Na}$ atividade 3, apresentamos três cartas publicadas na mídia e que usavam de argumentação para reclamar sobre problemas do cotidiano. Embora esse gênero 
pertença à esfera da cidadania, circulam em jornais e revistas; porém, não foi possível encontrarmos exemplares em situações idênticas à analisada, pois os órgãos competentes não disponibilizam essas produções a terceiros. Por isso, selecionamos exemplares em situações análogas que nos serviram como parâmetros de produção.

Organizamos a sala em duplas, para que pudéssemos ler as cartas e responder às atividades. A leitura foi feita em voz alta por mim e os alunos acompanharam com uma cópia em mãos.

\section{Carta 1 Lima \\ Carta ao Secretário do Meio Ambiente da Prefeitura Municipal de Nova}

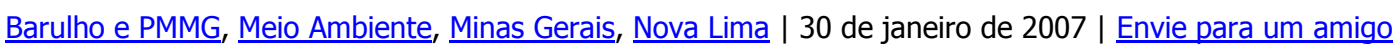

IImo. Sr.

Antonio Henriques dos Santos

DD Secretário do Meio Ambiente da Prefeitura Municipal de Nova Lima (MG)

Senhor Secretário,

Há anos que minha família e vizinhos sofremos o barulho constante e insuportável de ruídos - música, karaokê, vozes, gritos, manifestações ruidosas várias - provenientes da Pizzaria Mirante do Jambreiro, situada, sabidamente, em área residencial onde não é permitido atividades ruidosas diurnas ou noturnas; e que ainda não respeita outras exigências básicas como o revestimento acústico e a observância de horários, etc. Fizemos já inúmeras tentativas de dialogar com o proprietário do estabelecimento, a fim de que reconhecesse a irregularidade do seu comportamento incivilizado, sem êxito algum; fomos, em vista disto, obrigados a fazer, por meio de BOs da PMMG, inúmeras denúncias contra a Pizzaria. O Juiz Francisco Antonio Furtado Ribeiro acaba de exigir, em despacho assinado em 29 de dezembro e enviado ao Maj. Comte. Jaime da Silva, que a PM ao fazer ocorrências solicitadas contra a mesma Pizzaria se faça "acompanhar de um técnico do meio-ambiente da Prefeitura Municipal de Nova Lima, para que, por ele, seja averiguado se está havendo ou não excesso sonoro em relação ao que dispõe a Lei Estadual 10.100/90".

No entanto, o Ofício n. 249/05- SEMAM, dessa Secretaria, datado do mesmo dia 29 de dezembro último, dispõe que a fiscalização dos seus plantões sejam "realizados apenas aos sábados e domingos"( grifos meus). Esta disposição tolhe à PM um instrumento do seu trabalho julgado indispensável pela autoridade judicial e desatende as nossas exigências de sossego, assim como deve desatender a grande parte da população de Nova Lima que passará, então, nas sextas feiras, sobretudo, a viver imersa no barulho e à mercê dos abusos de empresários cultural e civicamente despreparados como o da Pizzaria do Jambeiro.

Solicitamos que esta Secretaria mude, assim, a referida orientação e disponha, como deseja e necessita a população e determina a autoridade judicial, a fiscalização dos seus "plantões" em todos os horários, diurnos e noturnos, de todos os dias da semana;

No aguardo de uma positiva compreensão e atendimento das exigências acima, somos atenciosamente, Fernando Massote

Fonte: Disponível em: http://massote.pro.br/2007/01/carta-ao-secretario-do-meio-ambiente-daprefeitura-municipal-de-nova-lima-mg/. Acesso em 07/03/2014 


\section{Carta 2}

Porto Alegre (RS), $1^{\circ}$ de fevereiro de 2010.

Senhor Diretor do Departamento de Trânsito de Porto Alegre:

No último dia 20, recebi uma multa relativa a uma infração cometida em $1^{\circ}$ de dezembro de 2009. A multa foi lavrada no cruzamento da Avenida Getúlio Vargas com a Rua Freitas Coutinho, às 15 horas, e se deu pelo fato de ter sido avançado o sinal vermelho.

Recordo-me bem da ocasião e admito que infringi uma norma do trânsito; aliás, uma “infração gravíssima”, de acordo com o novo Código de Trânsito. Porém, V.S. ${ }^{a}$ já viveu a desagradável situação de cruzar um semáforo, estando atrás de um ônibus de três metros de altura? Pois foi o que me aconteceu. Embora guardasse uma distância razoável do ônibus, sua altura não me permitia ver se o sinal estava ou não aberto. Como o ônibus não parou nem diminuiu a velocidade, achei que estivesse aberto e segui em frente.

Além disso, notei que o motorista que vinha atrás de meu veículo acelerou seu automóvel ao nos aproximarmos do cruzamento, o que me impediu completamente de parar ou esperar que o ônibus se afastasse para poder ver o semáforo, pois do contrário corria o sério risco de ter meu carro colidido na parte traseira.

Por outro lado, será que o ônibus ou o veículo de trás também foram multados? Ou será que o policial de trânsito não teve tempo de anotar a chapa dos outros dois veículos, fazendo-me sua única vítima? Teria havido coerência por parte do policial ao lavrar essa multa?

Gostaria de lembrar ainda que, em mais de vinte anos como motorista, jamais fui multado, o que comprova o quanto minha conduta tem sido correta no trânsito e o quanto essa multa é injusta.

Peço a V.S. ${ }^{a}$ que examine esse caso de uma forma mais ampla, distinguindo, de forma clara, aqueles que realmente merecem ser multados daqueles que merecem ser compreendidos e, portanto, perdoados.

Sem mais para o momento, agradeço sua compreensão,

Victor Hugo Sanches

Fonte: Disponível em:

http://www.guiadedireitos.org/index.php?option=com content\&view=article\&id=534\&ltemid=116.

Acesso em 07/03/2014

\section{Carta 3}

Quero fazer uma denúncia sobre as condições de transporte no Vale do Ribeira. A Intersul, única empresa que realiza transporte de passageiros na região (há muitos anos invicta), sem concorrentes, deixa muito a desejar em vários aspectos: Ônibus sujos, com banheiros imundos, sem respeito aos horários (que invariavelmente não são cumpridos), linhas e horários que, simplesmente, num dado momento são retirados sem nenhuma satisfação aos usuários que têm que se virar e dar um jeito para chegarem ao seus destinos. Pessoas que marcaram consultas em médicos ou tem compromissos com horários, ficam à mercê dessa empresa que não se importa com nada a não ser seus lucros. Exemplo do descaso foi o que ouvi numa agência, de uma funcionária que insistia em conferir o recebimento das passagens junto ao motorista (que além de conduzir o veículo, ainda tem que cobrar as passagens), quando o motorista, preocupado com o horário avançado da saída do ônibus, pediu para a funcionária o liberar e, a mesma respondeu: "Os passageiros que esperem". Isso é uma amostra do descaso e desrespeito com os usuários desta empresa, sem que nenhuma autoridade tome providências e cobre para que ela cumpra com a prestação de serviços a que está condicionada. 
Deixo assim, minha indignação esperando que seja feito algo para que se mude essa realidade.

Vagner da Cruz Martins

Postado há 4th October 2013 por JORNAL REGIONAL

Fonte: Disponível em: http://regionaljornal.blogspot.com.br/2013/10/carta-do-leitor-reclamacaointersul.html. Acesso em 07/03/2014

Apesar dos exemplos conterem algumas inadequações da norma escrita, não tratamos desses aspectos, pois o objetivo era identificar a posição do remetente e a argumentação utilizada.

Após a leitura detalhada das cartas, discutimos sobre o ponto de vista de cada remetente, quem eram eles e se concordavam com suas reclamações. Os estudantes relataram experiências pessoais semelhantes às das cartas, como por exemplo: vizinhos que ouviam música a qualquer hora, brigas em família, dificuldades de transporte na cidade, má conservação dos ônibus etc. Em relação à segunda carta, dado o ponto de vista ser de um motorista, foi a que menos despertou a interação entre os alunos. Isso mostra a importância da escolha dos conteúdos temáticos para o ensino de um gênero. Quanto mais a temática se aproxima da realidade do aluno, mais sentido faz para ele a aprendizagem do gênero. Isso, porém, não acontece com os materiais didáticos elaborados para um universo amplo de interlocutores.

Em seguida, apresentei uma ficha a ser preenchida com as informações retiradas dos textos lidos:

\begin{tabular}{|l|l|l|l|}
\hline Item & Carta 1 & Carta 2 & Carta 3 \\
\hline $\begin{array}{l}\text { Quem é o } \\
\text { interlocutor? }\end{array}$ & & & \\
\hline $\begin{array}{l}\text { Quais palavras se } \\
\text { referem ao } \\
\text { interlocutor }\end{array}$ & & & \\
\hline $\begin{array}{l}\text { Quais } \\
\text { argumentos } \\
\text { utilizados foram } \\
\text { utilizados? }\end{array}$ & & & \\
\hline Outros elementos & & & \\
\hline
\end{tabular}


Como a palavra argumento ainda era pouco conhecida pelos estudantes, fiz uma contextualização sobre argumentação. Costumo pedir a eles para solicitarem algo como a permissão para ir ao banheiro e, em seguida, eu nego. Eles ficam sem saber o que fazer e peço-lhes que insistam sem se repetirem, assim começam os argumentos: que estão "apertados", que não tem ninguém lá fora, que é a quinta aula. Explico-Ihes que esses são argumentos para essa situação, ou seja, são motivos para persuadir o outro. Outra estratégia é perguntar o que eles fazem para convencer os pais a autorizar algo que, a princípio, já sabem que será negado. Antecipo que não vale ficar insistindo com a repetição e, muito menos, usar artifícios como choro, expressões faciais, mas que devem utilizar apenas palavras. Estas informações facilitaram aos alunos identificar os argumentos utilizados na carta. Circulei entre os grupos para me certificar de que todos conseguiram completar a atividade.

Outro termo que gerou discussão foi a palavra interlocutor, aproveitei as dúvidas para mostrar as escolhas de palavras, conforme o destinatário da carta. Não aprofundei o procedimento, mas foi discutido o grau de formalidade adequado à situação de comunicação.

Em outra aula, iniciamos a atividade 4. Comecei a aula perguntando se eles acreditavam que suas cartas foram convincentes, se as autoridades se sentiriam na obrigação de resolver os problemas apontados por eles. Não houve resposta produtiva, somente uma inquietação dominou a sala.

Em seguida apresentei alguns recortes do texto da Constituição Federal, Brasil (1998), com dois artigos relativos ao direito individual e coletivo.

\section{TÍTULO II \\ Dos Direitos e Garantias Fundamentais \\ CAPÍTULO I \\ DOS DIREITOS E DEVERES INDIVIDUAIS E COLETIVOS}

Art. $5^{\circ}$ Todos são iguais perante a lei, sem distinção de qualquer natureza, garantindo-se aos brasileiros e aos estrangeiros residentes no País a inviolabilidade do direito à vida, à liberdade, à igualdade, à segurança e à propriedade, nos termos seguintes:

I - homens e mulheres são iguais em direitos e obrigações, nos termos desta Constituição; lei;

II - ninguém será obrigado a fazer ou deixar de fazer alguma coisa senão em virtude de

III - ninguém será submetido a tortura nem a tratamento desumano ou degradante; 
IV - é livre a manifestação do pensamento, sendo vedado o anonimato;

V - é assegurado o direito de resposta, proporcional ao agravo, além da indenização por dano material, moral ou à imagem;

VI - é inviolável a liberdade de consciência e de crença, sendo assegurado o livre exercício dos cultos religiosos e garantida, na forma da lei, a proteção aos locais de culto e a suas liturgias;

VII - é assegurada, nos termos da lei, a prestação de assistência religiosa nas entidades civis e militares de internação coletiva;

VIII - ninguém será privado de direitos por motivo de crença religiosa ou de conviçção filosófica ou política, salvo se as invocar para eximir-se de obrigação legal a todos imposta e recusar-se a cumprir prestação alternativa, fixada em lei;

IX - é livre a expressão da atividade intelectual, artística, científica e de comunicação, independentemente de censura ou licença;

X - são invioláveis a intimidade, a vida privada, a honra e a imagem das pessoas, assegurado o direito a indenização pelo dano material ou moral decorrente de sua violação;

$\mathrm{XI}$ - a casa é asilo inviolável do indivíduo, ninguém nela podendo penetrar sem consentimento do morador, salvo em caso de flagrante delito ou desastre, ou para prestar socorro, ou, durante o dia, por determinação judicial;

XII - é inviolável o sigilo da correspondência e das comunicações telegráficas, de dados e das comunicações telefônicas, salvo, no último caso, por ordem judicial, nas hipóteses e na forma que a lei estabelecer para fins de investigação criminal ou instrução processual penal; (Vide Lei ํㅜ 9.296, de 1996)

XIII - é livre o exercício de qualquer trabalho, ofício ou profissão, atendidas as qualificações profissionais que a lei estabelecer;

XIV - é assegurado a todos o acesso à informação e resguardado o sigilo da fonte, quando necessário ao exercício profissional;

$X V$ - é livre a locomoção no território nacional em tempo de paz, podendo qualquer pessoa, nos termos da lei, nele entrar, permanecer ou dele sair com seus bens;

$\mathrm{XVI}$ - todos podem reunir-se pacificamente, sem armas, em locais abertos ao público, independentemente de autorização, desde que não frustrem outra reunião anteriormente convocada para o mesmo local, sendo apenas exigido prévio aviso à autoridade competente;

XVII - é plena a liberdade de associação para fins lícitos, vedada a de caráter paramilitar;

XVIII - a criação de associações e, na forma da lei, a de cooperativas independem de autorização, sendo vedada a interferência estatal em seu funcionamento; 
XIX - as associações só poderão ser compulsoriamente dissolvidas ou ter suas atividades suspensas por decisão judicial, exigindo-se, no primeiro caso, o trânsito em julgado;

XX - ninguém poderá ser compelido a associar-se ou a permanecer associado;

XXI - as entidades associativas, quando expressamente autorizadas, têm legitimidade para representar seus filiados judicial ou extrajudicialmente;

XXII - é garantido o direito de propriedade;

$[\ldots]$

XXXII - o Estado promoverá, na forma da lei, a defesa do consumidor;

XXXIII - todos têm direito a receber dos órgãos públicos informações de seu interesse particular, ou de interesse coletivo ou geral, que serão prestadas no prazo da lei, sob pena de responsabilidade, ressalvadas aquelas cujo sigilo seja imprescindível à segurança da sociedade e do Estado; (Regulamento) (Vide Lei no 12.527, de 2011)

XXXIV - são a todos assegurados, independentemente do pagamento de taxas:

a) o direito de petição aos Poderes Públicos em defesa de direitos ou contra ilegalidade ou abuso de poder;

b) a obtenção de certidões em repartições públicas, para defesa de direitos e esclarecimento de situações de interesse pessoal;

\section{$[\ldots]$}

XLII - a prática do racismo constitui crime inafiançável e imprescritível, sujeito à pena de reclusão, nos termos da lei;

XLIII - a lei considerará crimes inafiançáveis e insuscetíveis de graça ou anistia a prática da tortura , o tráfico ilícito de entorpecentes e drogas afins, o terrorismo e os definidos como crimes hediondos, por eles respondendo os mandantes, os executores e os que, podendo evitá-los, se omitirem;

XLIV - constitui crime inafiançável e imprescritível a ação de grupos armados, civis ou militares, contra a ordem constitucional e o Estado Democrático;

$[\ldots]$

CAPÍTULO

DOS DIREITOS SOCIAIS

Art. 6 São direitos sociais a educação, a saúde, a alimentação, o trabalho, a moradia, o lazer, a segurança, a previdência social, a proteção à maternidade e à infância, a assistência aos desamparados, na forma desta Constituição. (Redação dada pela Emenda Constitucional nํ 64, de 2010)

Disponível em:

http://www.planalto.gov.br/ccivil 03/constituicao/constituicaocompilado.htm- acesso em $07 / 03 / 2014$ 
Os estudantes desconheciam o texto, assim como os outros Códigos existentes. Uma aluna me perguntou quantas leis havia. Fiz um breve resumo dos Códigos e suas aplicações. Coloquei na lousa:

Código Penal - leis sobre crimes em geral

Código Civil - leis que garantem direitos e deveres de família, do indivíduo

Código Processual Penal - leis que regem a administração pública

Código Florestal - leis que cuidam do meio ambiente

Além disso, coloquei no quadro a estrutura do texto jurídico, explicando-lhes que cada categoria comportava outra divisão, até chegar ao item que constituía o último segmento desse gênero textual, ou seja, que dentro do título pode haver capítulos, dentro desses vários artigos. Dentro dos artigos, vários incisos e nestes as alíneas e assim por diante.

Título: I, II, III...

Capítulo; I, II, III...

Artigos: $1^{\circ}, 2^{\circ}, 3^{\circ}, 4^{\circ}$....

Parágrafos $\S^{\circ} \stackrel{\circ}{ }, \S^{\circ}, \S^{\circ} 3^{\circ} \ldots .$.

Inciso: I, II, III, IV, V....

Alíneas: a, b, c, d ....

Item : 1, 2, $3 \ldots$

$\mathrm{Na}$ sequência, mostrei-lhes na folha que tinham nas mãos, os tópicos e seus respectivos nomes, a organização do texto em títulos, capítulos, artigos, parágrafos, inciso, alíneas, item.

Quando iniciei a leitura, após explicar a função da Constituição Federal, começaram os problemas. Uns alunos conversavam entre eles, outros queriam dormir, alguns ouviam a leitura, mas não olhavam para o papel. Contei apenas quatro ou cinco alunos que acompanhavam, olhando para o texto. Mesmo assim, a cada inciso, fazia uma parada, questionando-os se sabiam que aquele assunto era um direito e se estava sendo cumprido. Quando não entendiam o teor do texto, dava-Ihes um exemplo prático, por exemplo, a casa é um lugar inviolável, quer dizer que ninguém pode entrar sem ter permissão do dono, a não ser com um mandado. 
Muitas vezes, essas considerações geraram debate, pois cada um queria dar exemplo de como já viram ocorrências que contrariavam esses princípios.

Como não consegui envolver a maioria dos alunos, a leitura não progrediu conforme o esperado. Uma das hipóteses desse resultado seria o fato de ter colocado uma expectativa acima das condições reais dos alunos. Muitas vezes, o professor por ser um leitor mais experiente, não se coloca no lugar do outro, prevendo as dificuldades que o aluno pode enfrentar. Hoje percebo que qualquer texto da esfera jurídica está muito distante desses alunos. Ainda mais um texto com linguagem formal, sobre o qual muitos profissionais da área jurídica produzem diferentes interpretações. Com a intenção de aprofundar o conhecimento de mundo dos alunos, mudei a estratégia na aula seguinte. Solicitei a sala de multimídia e projetei o texto no datashow. Dessa vez não entreguei o texto para os alunos, pois pretendia que todos acompanhassem a leitura comigo. Houve, de fato, uma participação melhor por parte dos alunos. Neste mesmo dia, em outra aula, organizei a turma em grupos, entreguei a eles o texto e uma comanda com as questões abaixo para responderem, tendo como o objetivo de reconhecer informações que pudessem utilizar na reescrita da carta.

Questões

1- Como vimos durante a leitura, o texto jurídico/legal é estruturado em títulos, capítulos, seções, artigos, parágrafos. Localize em qual parte está o problema, apontado por vocês na carta. Indique o artigo, parágrafo e inciso, se houver.

2- Na sua opinião, qual(is) direito(s) elencado(s) no caput do artigo $5^{\circ}$ não são cumpridos? Justifique.

3- Quanto aos direitos sociais previstos no artigo 6ํㅡ, você considera que a lei está sendo cumprida?

4- Releia o texto e procure um ou mais direitos que você desconhecia e que diz respeito às pessoas com as quais convive. Transcreva-os e justifique sua escolha.

5- Você achou a linguagem utilizada por esse texto de fácil compreensão? Por quê? Em quais outros textos ela é normalmente utilizada?

Destacamos aqui algumas respostas: as respostas comuns à questão 2 foram sobre direito à segurança e à saúde. Na questão 3 apareceram os direitos à 
igualdade, principalmente entre ricos e pobres, brancos e negros. As demais questões ou eram objetivas, tal como localizar informação no texto ou subjetivas, tendo respostas muito variadas.

O passo seguinte, atividade 5 , foi a correção coletiva de uma carta. Pedi a autorização de alguns alunos para ler a carta para os colegas. As cartas selecionadas foram:

\section{Carta 1}

Cruzeiro, dia 19 de março de 2014

Setor de Saúde

Olá, queria fazer o pedido de mais médicos nos postos de saúde e na Santa casa, para evitar fila de espera e para melhor atender a população.

Obrigada pela atenção

J. R.

\section{Carta 2}

Cruzeiro, 19 de março de 2014

Promoção social

Olá estou escrevendo essa carta porque poderia tirar os mendigos das ruas de cruzeiro.

Eu não tiro porque não tenho condições, mas vocês podem não gosto de passar debaixo da ponte e ver eles lá vocês podem tomar uma providência sobre isso e eu acho que do mesmo jeito que todos tem seu abrigo eles também podem ter.

B.

Podemos perceber que o discurso dos autores, apesar de ser ainda embrionário no sentido da argumentação, explora os sentimentos do interlocutor. Principalmente na carta dois, o enunciador leva o interlocutor a refletir e se colocar, não só no lugar tanto dos mendigos, quanto no seu próprio lugar, como cidadão. Aqui, podemos afirmar que a persuasão se dá por meio do pathos, um dos meios 
persuasivos citados por Aristóteles em sua Retórica. Como no trecho: "Eu não tiro porque não tenho condições, mas vocês podem. "Nesse caso, delega ao interlocutor a responsabilidade do que pode vir a acontecer.

Analisando, hoje, as produções dos alunos, é perfeitamente compreensível que por falta de experiência não centrem sua argumentação por meio do discurso (logos), e tampouco por não possuírem, ainda, uma autoimagem como cidadãos (ethos), os alunos não fizeram a escolha mais adequada à situação. A carga expressiva marcada pela concisão dos textos lembra-nos as questões levantada por Bakthin (2013) em seu artigo "Questões de estilísticas nas aulas de Língua". Pois, assim como o abandono do uso do período composto por subordinação sem conjunção marca a escolarização dos alunos do pesquisador, aqui a escolha de períodos longos mantém traços de personalidade de um autor jovem, sem preocupação com as formas adequadas a uma situação de maior monitoramento (§2 da carta 2). As construções seguem a velocidade do pensamento e traduzem marcas do diálogo pretendido em uma carta. Lembra-nos, também, o que Bazerman (2011) afirma serem vestígios das primeiras cartas, ou seja, um texto que pretende substituir a presença física do enunciador.

A análise acima foi feita à posteriori, pois a primeira impressão do professor quando recebe textos escritos sucintamente, é questionar o porquê de seus alunos não escreverem textos mais substanciais em termo de volume de palavras. Esquecemos, muitas vezes, que a geração da era digital tem uma tendência natural para abreviar a informação. Haja vista os textos que circulam nas redes sociais e as respostas dadas nas atividades em sala de aula.

Por ocasião da correção coletiva, questionei-os se o autor foi convincente, se poderiam ser acrescentados outros argumentos. Também perguntei se a linguagem estava adequada ao interlocutor, se conseguíamos identificar um destinatário real, visto que, principalmente na carta 1 , o discurso é genérico e não parece interagir com um responsável em particular. A tendência dos alunos em atividades como essa é concordar com o autor com receio de terem que justificar qualquer outra escolha. Sugeri alguns argumentos que poderiam ser utilizados naquela situação, relembrei as cartas estudadas, o texto da Constituição Federal; entretanto, a atividade não progrediu como esperado. Além de não terem a prática da revisão, talvez o discurso do texto jurídico tenha inibido suas intervenções. Mesmo assim passei para a atividade de reescrita. 
Abaixo estão transcritas as segundas versões das cartas reproduzidas anteriormente; respectivamente, temos:

Carta1-reescrita

Cruzeiro, dia 31 de março de 2014

Setor de Saúde

Olá, queria fazer a reclamação sobre a saúde, a falta de médico nos postos, Santa Casa, a falta de remédio também.

Isso tudo é perigoso, coloca a vida da população em risco e temos nossos direitos como diz a lei, artigo 6, Capítulo II da Constituição Federal.

Agradeço a atenção e espero que o problema seja resolvido.

J.R.

Percebemos que houve um progresso quanto à argumentação. A aluna acrescentou argumentos, indicando as consequências do problema apontado. Além disso, citou a lei que foi estudada, ainda que não tenha explicitado o teor do referido artigo e também não tenha estabelecido a relação entre o texto referenciado e seu argumento. Constatamos aqui a transição citada por Bakthin (2003), na qual os nossos alunos do $9^{\circ}$ ano, assim como os da $7^{\underline{a}}$ série da escola russa, começam a experimentar a língua em um nível mais formal.

Carta 2- reescrita

Cruzeiro, 31 de março de 2014

Promoção social

Olá, estou escrevendo essa carta porque poderia tira os mendigos das ruas de Cruzeiro.

Eu não tiro porque não tenho condições, mas vocês podem. Não gosto de passar embaixo da ponte e ver eles lá vocês podem tomar uma providência sobre isso e eu acho que do mesmo jeito que todos tem seu abrigo eles também podem ter e querem com certeza porque eles precisam disso já que vocês não querem fazer essa caridade procurem a família deles porque vocês não querem abrir um 
lugar só para mendigo mas eu gostaria de ter condição para tira todos da rua e ajuda as pessoas ao máximo possível mas fico muito feliz se vocês fazerem o que eu pedir.

B.

Nessa reescrita, a argumentação reforça o pathos, pois a reincidência do pronome de tratamento relacionado às ações pretendidas pela enunciadora comprova a intenção de sensibilizar o ouvinte, como nos trechos: " eu não posso...mas vocês podem"; “...já que vocês não querem fazer essa caridade..." e " fico feliz se vocês fazerem) (sic). Até mesmo a ausência da pontuação para marcar os períodos do segundo parágrafo sugere uma maior proximidade com 0 interlocutor, deixando o texto mais expressivo, colaborando com o discurso apoiado no pathos.

Em um primeiro momento, pensamos em fazer uma limpeza do texto para analisar em seguida. Mas, ao pontuar o texto, percebemos que o caráter aproximante do interlocutor desaparece. Deixa de ser um texto fluido, convincente, com pouca expressividade, enfraquecendo a própria argumentação. Concluímos que os recursos linguísticos argumentativos vão além das questões gramaticais, comumente valorizadas nas aulas de língua portuguesa, compreende também o estilo do autor.

Para melhor ilustrar que a tentativa de se aproximar de modelos mais formais, ainda se encontra em formação, reproduziremos as duas versões de outro aluno. Este se destaca por ser mais politizado, leitor crítico e o único da sala que relatou ter pai com ensino superior completo

$1^{\text {a }}$ versão

(não se dirigiu a nenhum setor)

Eu escrevo essa carta primeiramente com o objetivo de avisar e sensibilizar as pessoas e talvez até ajudar a achar as pessoas que desrespeitam lugares públicos com sons estrondosos, e totalmente libertinos pois penso eu que qualquer som que possa incomodar com o que diz ou a altura que possa incomodar ilegal dever ser.

K.A. 
$2^{\text {a }}$ versão

Secretaria do meio-ambiente...

Venho aqui comunicar um problema que incomoda eu e minha família, como quando vamos a um lugar público, um ônibus por exemplo, e alguém entra com caixas de som, celulares ou qualquer outro aparelho que perturbe pela altura do volume, ou se ele faz alguma apologia a sexo, coisas fora da lei e qualquer outra coisa que é libertinamente. Eu não sofro com bailes, bares, sações e outras coisas que podem atrapalhar e ferir os direitos de um cidadão, pois sei eu, que muitas pessoas sofrem com tal coisa.

As consequências são muitas vezes falta de sono, "stress", podendo até causar brigas e dependendo até mortes, assim transformando um probleminha em "o problemão" tenho certeza que encontraremos uma solução para isso.

Eu acredito profundamente que, por um simples fato de ética e consciência pelo ser humano, aprender a ter limites, como só ouvir musicas com fone de ouvido, e em festas e outras comemorações só colocar musicas muito altas sexta-feira de noite, sabado o dia inteiro, e domingo até 22 horas, pois sabemos que a poluição sonora, nos priva até de estudar além de dar dores de cabeça eventualmente.

$$
\text { K.A.A. }
$$

Tendo em vista o objetivo dessa sequência de atividade e como, na primeira versão, percebi a ausência de argumentação, consistindo a maioria dos textos na descrição ou informação do problema, orientei-os sobre a necessidade de indicar motivos para que fossem atendidos, especificando a ação que gostariam que os responsáveis tomassem, informando o nome das ruas com problemas, adequassem a linguagem ao destinatário (interlocutor).

$\mathrm{Na}$ segunda versão, temos exemplos em que o aluno tentou seguir as orientações, expandindo sua argumentação, incluindo o setor (Secretaria do Meioambiente), organizando o texto em três parágrafos: apresentando o problema, indicando as consequências e sugerindo intervenções. Entretanto, percebemos construções que contrariam as normas gramaticais, como, por exemplo: "incomoda eu e minha família”, "...ou se ele faz alguma apologia a sexo" (não podemos definir um referente lógico-discursivo; o mais provável seria alguém, mas o distanciamento e a pontuação não esclarecem o leitor). Em outro trecho "....outra coisa que soe 
libertinamente", percebemos que as escolhas lexicais denotam uma prática de leitura, mas apresentam um escritor em fase de construção.

Vale ainda ressaltar que a pontuação sofreu neste texto intervenções motivadas pelos exercícios decorrentes da correção coletiva. As propostas de atividades estão no anexo (D); nelas, procuramos refletir sobre o valor semântico da vírgula e do ponto final. Percebemos na produção do aluno a hipercorreção quanto ao uso da vírgula, substituindo, muitas vezes, o ponto por este sinal. Ainda que o estudante saiba usar alguns sinais, como, por exemplo, as aspas no termo "o problemão", ainda não possui um domínio do uso do ponto final, causando até mesmo uma ambiguidade no segundo parágrafo: "assim transformando um probleminha em "o problemão" tenho certeza que encontraremos uma solução para isso". Pelo contexto, sabemos que não é intenção dizer que a solução seria transformar um probleminha em "o problemão", mas a leitura literal, sem o encerramento do período após o termo grifado, causa essa ambiguidade.

Isso nos remete ao comentário que Bakthin (2003) faz sobre seus alunos, que, por serem inexperientes e ao tentarem se aproximar da linguagem uniformizada dos manuais, produzem textos ainda mais uniformizados e inexpressivos. O mesmo acontece com esse aluno: a preocupação com o léxico e o uso dos sinais apreendidos faz com que seu discurso seja, em algumas partes, truncado. Embora volumoso em palavras, é impreciso quanto ao interlocutor e quanto à intencionalidade ( o que se pretende do setor responsável).

Mesmo motivando a todos para reescreverem seus textos, apenas 11 alunos se propuseram a fazer a atividade. Desses, apenas 6 acrescentaram argumentos ou melhoraram a descrição do problema, conforme vimos nos exemplos citados acima.

Em seguida, reproduzimos mais um exemplo de produção e reescrita.

$1^{\text {àv} \text { versão }}$

Cruzeiro, 19 de março de 2014

Secretaria de Saúde

Olá. Como vai?

Queria pedir ajuda a vocês sobre a falta de médicos na Santa Casa e nos postos de saúde de Cruzeiro. 
Muitas pessoas estão reclamando do atendimento na Santa Casa. É demorado demais, ainda mais para os idosos e para as grávidas. E também tem que melhorar a limpeza, também está faltando cadeiras para sentar, macas, etc. É necessário mais enfermeiros. Peço suas ajuda e para o bem nosso e seus. Obrigada!

G.M.

$2^{\text {a }}$ versão

Cruzeiro, 31 de março de 2014

Senhor Secretário de Saúde

Olá, como vai?

Queria pedir ajuda a vocês sobre a falta de médicos na Santa Casa e nos postos de saúde de Cruzeiro. Já vi mulheres grávidas tendo que esperar, mesmo tendo contrações, crianças doentes e isso deve ser resolvido, isso já passou dos limites. O lugar é abafado e sujo, as pessoas são mal atendidas.

Eu não tenho que passar muito por isso, mas eu vejo os sofrimentos das pessoas por não serem bem tratadas e não recebendo aquilo por direito.

Um bom jeito de resolvermos isso seria se selecionassem melhores médicos e enfermeiros. Assim, mesmo com poucas pessoas trabalhando daria o melhor tratamento. Também aumentando a produtividade de remédios em laboratório.

Obrigada

\section{G.M.}

A pessoalidade marca a argumentação da estudante, assim como na carta de B., ela mostra sensibilidade pelos problemas alheios e busca envolver o interlocutor na sua causa.

A premissa que supôs o domínio do gênero por ser um texto facilmente reconhecido não se confirmou, pois foram poucos os alunos que consideraram seu interlocutor como alguém responsável pela resolução do problema. Alguns textos se aproximam de campanhas publicitárias, carta aberta à população e avisos. 
No exemplo anterior, percebemos que, nas duas versões, os termos que se referem ao interlocutor permanecem na terceira pessoa do plural, deixando claro que a aluna não sabe ao certo quem lerá sua carta. Talvez imagine a instituição como um conjunto de pessoas e, por isso, utilize essa forma no pronome de tratamento. Entretanto, já podemos perceber uma intenção argumentativa, ainda que haja ausência de planejamento. Houve uma reformulação do primeiro parágrafo, uma alusão aos direitos dos usuários do sistema de saúde. Além disso, a autora já ensaia uma proposta de intervenção (último parágrafo).

Após a reflexão sobre o progresso da turma, sobre suas dificuldades e das possibilidades de trabalho, foram planejadas outras atividades que, em nosso ponto de vista, favoreceriam o desenvolvimento das habilidades requeridas para a produção de um artigo de opinião, gênero esse, que seria avaliado no segundo semestre.

Até o momento, podemos concluir que os alunos possuem uma noção do que seja argumentação, pois demonstraram, no caso das cartas, que centrando a persuasão na disposição do ouvinte - um dos meios de persuasão, segundo a retórica aristotélica - teriam sucesso nos seus textos.

Outro aspecto a considerar são as escolhas linguísticas que definem o estilo do autor. Embora não seja o "modelo" que se espera do aluno daquela série, devemos não ser tão dogmáticos e considerar que muitas vezes, textos volumosos não possuem a carga argumentativa obtida ao se apelar à sensibilidade do interlocutor. Por isso, reconhecemos, assim como Bakthin (2003), que a reflexão sobre a língua é necessária para que a expressividade do texto não seja perdida em favor de uma uniformização gramatical, seja em qualquer gênero que ela se concretize.

Além disso, para o aluno ser competente em qualquer gênero é preciso oferecer a maior variedade de informação ao alcance do professor, tanto no que se refere ao gênero, quanto ao tema que irá constituir o discurso, pois, para ter uma atitude dialógica e responsiva sobre um assunto, é preciso primeiro ter experiências válidas sobre o que está em pauta. 
No próximo capítulo, abordaremos a sequência de atividades que culminaram na produção textual da AAP do segundo semestre. 


\section{CAPÍTULO 5}

\section{O ARTIGO DE OPINIÃO: DESENVOLVIMENTO DOS MÓDULOS DA SD}

No capítulo anterior, a sequência didática sobre a carta de reclamação foi trabalhada como forma de introduzir o estudante ao universo da argumentação. Neste, procuraremos avançar na compreensão e na produção de gêneros argumentativos pelos alunos do ensino fundamental por meio da produção do gênero artigo de opinião.

Dando sequência à descrição do desenvolvimento da $\mathrm{SD}$, as atividades a seguir correspondem aos seus módulos 2, 3 e 4. Todavia, vale lembrar que essas atividades não compreendem o total das aulas dadas no período pesquisado, pois o cumprimento do currículo prevê outras situações de aprendizagem que, embora contribuam para a melhoria da produção escrita, não estão diretamente relacionadas ao objetivo da nossa pesquisa, que é a análise de atividades de ensino/aprendizagem da argumentação em sala de aula.

Conforme foi apresentado no capítulo 2, a busca por atividades pertinentes ao nosso objetivo, associadas à valorização do material didático-pedagógico disponível, levou-nos a fazer escolhas que, no momento do planejamento, nos pareceram mais adequadas. Entretanto, com o devido distanciamento e uma reavaliação das recomendações dadas por Scheneuwly \& Dolz (2004), que orientam à preferência por sequências de curta duração, para não perder o foco do trabalho, percebemos que a intercalação de outras atividades e a duração da sequência prejudicaram de alguma maneira o processo de ensino/aprendizagem. Isso foi notado em diversos momentos nos quais foi necessário retomar os conteúdos e relembrar o objetivo das atividades.

A seguir, faremos uma breve descrição das atividades preparativas para a produção do artigo de opinião que se deu em 5 módulos. No módulo 2, analisamos um artigo de opinião. No módulo 3, o destaque foi para as atividades de leitura de textos na mídia digital e produção de argumentos em redes sociais. No módulo 4, realizamos atividades de leitura e análise de textos argumentativos do caderno do aluno. No módulo 5, fizemos a análise de um artigo de opinião. Para encerrar a 
sequência, foi proposta aos alunos uma produção de texto sobre o tema pesquisado no módulo 3 e, por fim, a produção final: a Avaliação de Aprendizagem em Processo.

\section{1- DESCRIÇÃO DO MÓDULO 2: ANALISANDO UM ARTIGO DE OPINIÃO}

O relato que se segue é composto pela voz da professora/pesquisadora; por isso em alguns momentos optou-se pelo uso da primeira pessoa do singular.

Após a devolutiva da carta e alguns comentários a respeito da produção feita por eles, lancei algumas perguntas. Tentamos, a princípio, gravar as aulas para reproduzir os relatos, porém, como não havia colaboradores disponíveis e a condução das aulas ficou prejudicada pela manipulação da câmera, decidimos contar com as anotações feitas posteriormente às aulas. Por isso, transcrevemos aqui algumas colocações que foram registradas de memória pela professora/pesquisadora.

$P$ : Na carta que produzimos, vocês deram sua opinião sobre um assunto. Quando podemos dar opinião em outras situações?

Respostas: "Quando não gostamos de alguma coisa." "Quando querem que a gente faça uma coisa que não queremos"

$P$ : Hoje vocês podem dar opinião sobre vários assuntos, mas vocês acham que foi sempre assim?

Respostas: "Acho que não" "não sei"

Ao exemplificar como era na minha época de escola, em casa, que não podíamos discutir e sim obedecer, ou seja, se fizéssemos algo, o professor destratava, humilhava, etc., alguns alunos se revoltaram.

Respostas: "É ruim que eu ia deixar a professora falar assim comigo"

$P: O$ que iria fazer?

Respostas: "Ah eu iria xingar ela"

$P: O$ que vocês acham que iria acontecer com ela?

Respostas: "O pai ou a mãe iria descer o pau nela (risos)

$P$ : Pessoal, é verdade. Não podíamos levar reclamações para casa.

Não existia a "Lei da palmada", nem o ECA. Vocês já ouviram falar deles? (Sim, já ouviram)

$P$ : Continuando. Vamos ler o título do texto "Mulheres precisam querer mais". O que vocês acham que as mulheres deveriam querer? Respostas: "Mais respeito", "mais direito"

$P$ : Direito de que?

Respostas: "De tudo" 
P: Vamos precisar melhorar isto. Mas por enquanto vamos esperar para ver o que o texto nos fala.

Notamos que a participação dos estudantes se dá de maneira concisa, porém, sabemos que os aspectos comunicacionais próprios da interação em sala de aula tendem a construir frases mais curtas. Wachowicz (2012) aponta que a sequência dialogal se aproxima da oralidade e, por isso, as construções se assemelham à fala. $O$ nosso objetivo, enquanto professores de língua portuguesa, entre outros, é garantir que, na escrita, o aluno possa se expressar de maneira a compensar os recursos extralinguísticos da fala. Mais adiante poderemos perceber que a influência da oralidade na produção textual dos alunos aparece tanto nos textos das avaliações, quanto nas participações da página da rede social.

Lemos a introdução dos autores do livro:

\begin{abstract}
Você vai ler um texto com as considerações de uma advogada a respeito de um assunto que tem merecido muita atenção nos dias de hoje. Por meio desse texto, você vai conhecer como ela se posiciona diante do tema e seus vários aspectos e ainda como justifica suas opiniões
\end{abstract}

DELMANTO e CARVALHO (2012.Pág.156)

Adotamos a leitura estudo-do-texto, apoiada em Geraldi (1991) como o tipo de entrada no texto que permite retirar tudo o que o texto pode oferecer ao leitor, e não procurar, apenas, por uma resposta pontual, delimitada previamente. Por isso, optamos por uma leitura pausada e compartilhada.

\footnotetext{
Mulheres precisam querer mais

O último censo do IBGE mostrou que as mulheres têm, em média, mais dois anos de educação que os homens. Mas, em que pese esse diferencial positivo, os salários pagos às mulheres ainda são, em média, 30\% menores que os dos homens, na mesma função. Outra constatação intrigante é a de que, quanto maior o nível educacional, maior a diferença entre os rendimentos masculinos e femininos.

Sabemos que o patriarcalismo se sustenta na pobreza da mulher. A ideia é que as mulheres não tenham dinheiro nem poder, precisem vender seu corpo para se sustentar, seja pela prostituição ou pelo casamento. Além disso, essa pesquisa mostrou que não basta ter mais educação formal para que a violência doméstica diminua. A correlação de forças entre os gêneros continua desigual e as mulheres permanecem sofrendo discriminações, tanto no espaço público quanto no privado.

O Brasil já tomou várias medidas para promover a igualdade de gênero. Começou pela Constituição federal, que estabelece direitos iguais, reconhece a união estável, cria a licença-paternidade, equipara os direitos dos filhos independentemente da situação dos pais. Vieram, também, as Delegacias de Defesa da Mulher, o crime de assédio sexual, a Lei Maria da Penha, as Varas de
} 
Violência Doméstica. Entendemos que a opressão feminina é milenar e não será banida do dia para a noite, mas com as possibilidades que temos hoje é de espantar que a maioria das mulheres ainda esteja em tamanha desvantagem. Em outras palavras, a marcha para uma vida melhor está devagar demais.

A dominação masculina transformou o mundo num lugar hostil às mulheres. Nos mínimos detalhes, as atividades profissionais remuneradas são organizadas para causar desconforto à mulher. Os ambientes são rígidos, os banheiros são sujos, o relacionamento com os outros é impessoal, os termos linguísticos são rudes, a nomenclatura dos cargos de comando está no masculino, as roupas são controladas e criticadas, isso tudo sem falar do assédio sexual ou moral, de forma que as mulheres sintam medo de ser mulheres. Assim, diante de tantas dificuldades, muitas desistem antes de tentar, outras alcançam uma posição razoável e se conformam; apenas algumas poucas ousam lutar para chegar o mais alto possível. É difícil resistir à tentação de se acomodar, de aceitar a subalternidade ou dedicar-se apenas ao marido e aos filhos.

Sim, gostamos de ser mães, de cuidar da casa e dos outros, mas isso não engloba todos os nossos anseios. Precisamos também de independência financeira, sexual e profissional, de respeito, de dignidade e de reconhecimento social. Para escapar da violência e mudar a correlação de forças temos de estar no poder. Mesmo que esse poder, instalado por homens para o bem dos homens, não seja o nosso ideal de vida. Ainda que pareça difícil suportar as contrariedades do ambiente hostil, não será possível evitar esta etapa evolutiva: ocupar os espaços para depois fazer as transformações. Enquanto as mulheres não tiverem a clareza de que é preciso querer mais, ambicionar o máximo e não se contentar com o mínimo, os bons níveis de escolaridade não serão suficientes para vencer a imposição de inferioridade.

Por outro lado, não podemos prescindir da colaboração dos homens nessa árdua jornada. E eles precisam começar modificando a forma como encaram as relações afetivas. Sobre esse tema, David Servan-Schreiber, médico francês que escreveu dois livros para contar sua luta contra o câncer, sintetizou o assunto na obra Podemos Dizer Adeus Duas Vezes. Depois de muita meditação e durante os momentos finais em que passou a rever sua vida, reconheceu que não soube amar as mulheres como gostaria de ter amado. Em suas palavras: "Quando eu era muito jovem, tinha a cabeça cheia de ideias imbecis sobre o assunto. Para mim, amor era coisa que o homem impunha à mulher, pois ela era por essência recalcitrante. $O$ único modo de agir era subjugá-la. Uma história de amor era em primeiro lugar uma história de conquista, depois uma história de ocupação. Pura relação de força, na qual o homem tinha interesse em se manter na posição dominante. Nem pensar em deixar-se levar, mesmo depois de ela se render. Como a dominação era ilegítima, ele devia vigiar constantemente sua conquista, devia mantê-la sob sua influência, se quisesse evitar que ela se rebelasse. Impossível imaginar uma relação harmoniosa, uma relação baseada na troca ou numa igualdade qualquer dos parceiros. Ainda me pergunto de onde me vinham aquelas ideias idiotas que deterioraram minhas histórias de amor até por volta dos meus 30 anos. Eu me esforçava por me comportar como potência ocupante. Minha busca amorosa se resumia à procura de um território para conquistar. Resultado: eu amava, às vezes loucamente, mas não era amado. Ou mesmo quando o era, não me autorizava a me sentir amado. Porque, nesse caso, precisaria depor as armas. Que 
tristeza ter perdido tanto tempo e tantas oportunidades de felicidade! Por fim, acabei me desvencilhando daquelas ideias grotescas, dei um salto quântico que me projetou anos-luz, num universo encantado em que as mulheres são dotadas de inteligência e conseguem compartilhar comigo uma infinidade de interesses comuns. Finalmente, fui capaz de viver verdadeiras histórias de amor, com mulheres que eram iguais a mim, humana e intelectualmente. Consegui abandonar o frustrante papel de tutor. Aprendi que há muito mais prazer em dar e receber do que em dominar ou impor-se pela sedução".

Talvez seja isso que nossas escolas tenham de ensinar para que os níveis de instrução formal possam fazer alguma diferença.

Luiza Nagib Eluf, Procuradora de Justiça do Ministério Público de São Paulo. Trabalhou no Conselho Estadual da Condição Feminina e é autora de vários livros, entre os quais $A$ paixão no banco dos réus, sobre crimes passionais, e Matar e ou morrer: o caso Euclides da Cunha.

O Estado de S. Paulo, 6 de dez.2011. Disponível em: <http://www.estadao.com.br/noticias/impresso,mulheresprecisam-querer-mais-,807255,0,htm>. Acesso em: 7 dez.2011.

Fonte: DELMANTO e CARVALHO.Jornadas.port, 9aa ano,2012, p. 158

Essa estratégia mostrou-se eficaz, pois, à medida que líamos, os estudantes iam fazendo intervenções. Posicionaram-se em relação ao tema, dando exemplos próximos a eles sobre a questão do machismo e do preconceito em relação à mulher, ou seja, tinham o que dizer.

Após a leitura do primeiro e segundo parágrafos, houve uma discussão para esclarecer a situação apresentada no texto: as injustiças contra a mulher. Alguns alunos argumentaram que não era bem assim, que as mulheres trabalhavam em qualquer lugar. Outros concordaram com a autora. Eu apontei para eles a informação do texto sobre os dados do IBGE e perguntei-lhes se sabiam o que significava. Após a explicação, houve uma conciliação das opiniões.

Em seguida, realizamos a leitura do terceiro parágrafo. Aqui enfatizei as medidas já adotadas e foram discutidas cada uma delas. Relembramos o texto lido sobre os Direitos Constitucionais. Vários alunos já conheciam a Lei Maria da Penha.

Os demais parágrafos foram lidos conjuntamente, mas foi preciso fazer uma leitura sem muitas pausas para não ultrapassar o horário da aula.

$\mathrm{Na}$ aula seguinte, retomamos o assunto sobre as dificuldades que as mulheres enfrentam na sociedade; comentamos sobre o Dia Internacional da Mulher e sobre as mulheres que desempenham papel importante no mundo. 
Durante a leitura, pudemos observar o aspecto dialógico da linguagem nas participações dos alunos. À medida que davam exemplo sobre o tema debatido, percebiam-se as vozes das famílias e do grupo social ao qual eles pertencem.

Iniciamos as atividades propostas pelo livro na seção Exploração do texto. $\mathrm{Na}$ primeira subseção "Nas linhas do texto", solicitei que respondessem sozinhos e circulei pela sala. As questões recuperam as ideias-chave do texto e fazem um resumo da temática desenvolvida. As questões eram as seguintes:

Nas linhas do texto

1. Que fato deu origem ao texto?

2. Por que esse é um fato relevante, isto é, merece ser discutido com os leitores?

3. Segundo o texto, como são os salários das mulheres em relação aos dos homens?

4. Que medidas foram tomadas pelo Brasil para promover a igualdade de gênero?

5. A autora do texto afirma: "não podemos prescindir da colaboração dos homens nessa árdua jornada". Que exemplo de colaboração masculina ela apresenta?

Quadro 11 - Atividade do livro didático. DELMANTO e CARVALHO.Jornadas.port, 9ª ano,2012, p. 158

No segundo bloco de questões "Nas entrelinhas do texto", utilizei outra estratégia, lendo as questões e discutindo as respostas. Aqui, começamos a sistematizar o gênero artigo de opinião.

Nas entrelinhas do texto

1. O texto que você leu é chamado de artigo de opinião. Com que finalidade foi redigido?

$O$ artigo de opinião é um gênero textual que circula na esfera jornalística. Pode ser publicado em jornais e revistas impressos ou virtuais e também apresentado oralmente na televisão e no rádio.

2. A autora do texto apenas registra o problema, dá opinião sobre ele ou apresenta a opinião de outras pessoas?

3. Qual é o leitor com o qual o artigo dialoga?

4. O artigo não se limita a abordar a situação da mulher na sociedade, apontando também a do homem. Justifique.

5. Releia o título do artigo. Como você o explica? Justifique.

6 . O artigo nega o papel da mulher como mãe e dona de casa? Justifique sua resposta com trechos do texto

Quadro 12 - Atividade do livro didático. DELMANTO e CARVALHO.Jornadas.port, 9ª ano,2012, p. 158

A questão 1 trouxe a reflexão sobre a finalidade do gênero e também informações sobre sua esfera de produção e circulação. 
As demais questões desse bloco abordavam o público alvo, as vozes presentes no texto, a posição do autor, ou seja, mobilizavam as habilidades de inferência, compreensão global e formulação de hipóteses. Nessa etapa, os alunos já demonstraram certa dificuldade para desenvolver as atividades.

$\mathrm{Na}$ aula seguinte, começamos pelo bloco "Além das linhas do texto". Havia uma letra de música; "Um a um", de Arnaldo Antunes que foi lida de modo compartilhado e debatida.

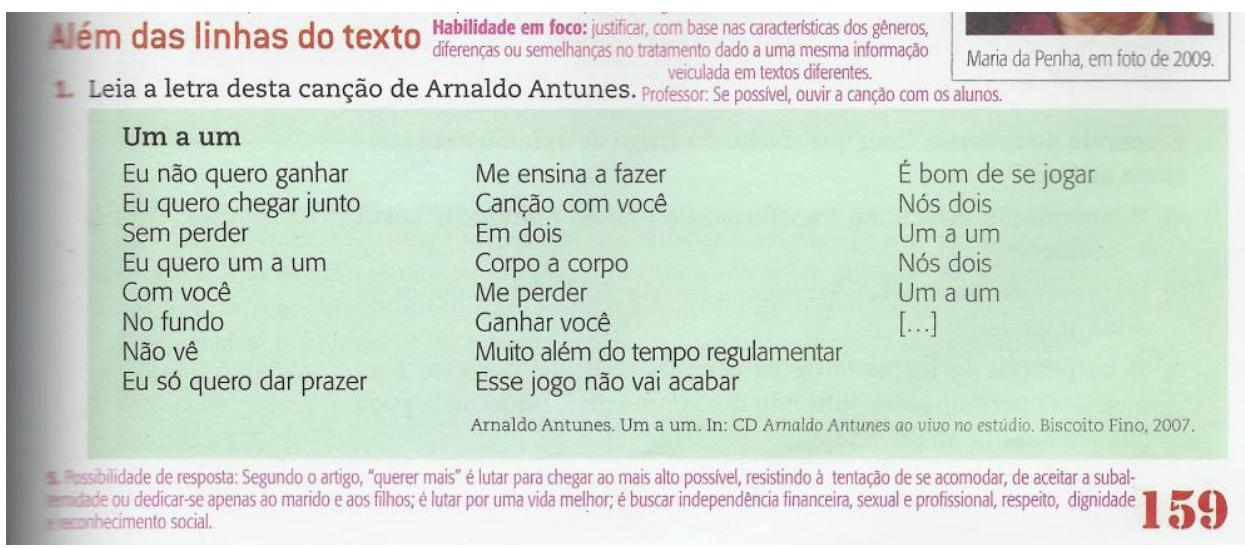

Figura 08 - Atividade do livro didático- DELMANTO e CARVALHO.Jornadas.port, 9aa ano,2012, p. 159

Somente pelo título, eles já associaram a um jogo. Mas como no corpo do texto se falava de relacionamento, rapidamente associaram ao assunto discutido, aos direitos iguais de ambos os sexos. Não tiveram também dificuldades em responder aos outros exercícios, pois a forma de apresentação com o uso de imagens, facilitou a compreensão.

A seção "Como o texto se organiza" precisou ser desenvolvida em várias aulas. Os enunciados não eram compreendidos e foram necessárias algumas intervenções para que se chegasse às respostas. Além disso, por meio de informações do enunciado, fomos construindo alguns conceitos referentes às características do gênero artigo de opinião, como, por exemplo, na questão 1, o portador do texto; na questão 2, referência do enunciador do texto; na questão 3, o conceito de questão polêmica ou controversa; já na questão 4, pergunta-se sobre a tese, trazendo um box, em que se conceitua esse elemento; na questão 5 , a posição assumida pela articulista é comparada com outros pontos de vista sobre o assunto que circula na sociedade. 


\section{Como o texto se organiza}

1. Em que tipo de portador foi publicado o artigo?

2. Os autores de artigos de opinião são, geralmente, pessoas que dominam o conteúdo que será discutido no texto. Releia os dados biográficos da articulista apresentados no final do texto. A autora está qualificada para escrever 0 artigo? Por quê?

3. Existem questões que são objeto de debates na sociedade e que, muitas vezes, ganham os jornais em forma de notícias, reportagens e artigos de opinião.

a) Qual é a questão que o artigo discute? A desigualdade entre homens e mulheres

b) Na sociedade em que vivemos, existe concordância de opiniões sobre a questão discutida? Explique.

No artigo de opinião, há sempre a presença de uma questão polêmica, pois esse gênero textual é construído em torno de assuntos controversos, que admitem diferentes olhares. $\mathrm{O}$ articulista assume e defende um ponto de vista em relação ao assunto.

2. Sim, ela é uma advogada e Procuradora de Justiça que trabalhou no Conselho Estadual da Condiçăo Feminina.
3. b) Não, há pontos de vista diferentes, pois há quem ache que as mulheres săo inferiores aos homens, que só podem realizar determinadas tarefas, que deven penas cuidar da casa e dos filhos etc

As mulheres não podem se aco-

4. Que posição ou tese a articulista defende no artigo? modar e devem lutar por respeito, nhecimento profissional e social.

Tese é a posição defendida pelo autor de um texto sobre determinado assunto. A tese sempre é fundamentada por meio de argumentos, isto é, por meio de razões que justificam por que se afirma ou se nega algo.

5. A posição assumida pela articulista dialoga com outros pontos de vista sobre $o$ assunto que circulam na sociedade. Identifique entre as teses abaixo a que está de acordo com a posição assumida no artigo e a que expressa um ponto de vista totalmente oposto.

a)

A desgraça humana começou no Éden: por causa da mulher, todos nós sabemos, mas também em virtude da ingenuidade, da tolice e da fragilidade emocional do homem. [...]

O mundo é masculino! A ideia que temos de Deus é masculina!

Juiz Edilson Rodrigues, recusando-se a aplicar a Lei Maria da Penha, em 2007.

b)

A discriminação contra a mulher é um fator que, na maior parte das vezes, está presente e fundamenta a violência sofrida. Coloca a mulher em situação de inferioridade e de subordinação, limitando sua autonomia, seu poder de escolha e de decisão, bem como o seu reconhecimento como pessoa dotada de direitos e de igual dignidade em relação ao homem.

Femanda Seara Contente e Mônica de Melo. O mundo privado como réu. Le Monde Diplomatique Brasil, nov. 2008.

De acordo com a posição assumida no artigo: as autoras também falam dá violência contra a mulher, que limita "o seu reconhecimento como pessoa dotada de direitos e de igual dignidade em relação ao homem."

Figura 09 - Atividade do livro didático DELMANTO e CARVALHO.Jornadas.port, 9a ano,2012, p. 161

Embora as questões estejam de acordo com as sugestões teóricas da análise discursiva, esse "destrinchamento" do texto foi tornando as atividades improdutivas, 
em parte pela linguagem dos enunciados se distanciar do domínio discursivo dos estudantes, em parte também pelo fato de muitas questões sobre o mesmo texto tornaram-se cansativas para o aluno. Solicitei que anotassem os boxes nos seus respectivos cadernos, pois eles traziam os elementos constitutivos do gênero: questão polêmica, tese, argumento, argumentação, tipos de argumentos. Era uma forma de ir sistematizando o artigo de opinião. Percebi que faziam mecanicamente as atividades e registrei isso para futuras intervenções.

Após a realização das atividades da seção Recursos linguísticos, na qual foram resolvidos exercícios que identificavam os articuladores textuais e suas respectivas finalidades, seguindo as orientações do caderno do aluno (SÃO PAULO, 2014, p. 13), solicitei que fizessem uma pesquisa nas minigramáticas que temos disponíveis e fizessem um levantamento de alguns exemplos de conjunções coordenativas. Eles foram orientados a não copiar os exemplos do livro e sim, a criar frases que falassem do assunto estudado no texto ou de outro tema polêmico desejado. Pedi também que anotassem no caderno o seguinte quadro apresentado no livro didático DELMANTO e CARVALHO, Jornada.port . 9ำ ano (2012, p.166):

\begin{tabular}{|l|l|}
\hline Finalidade & Articuladores textuais \\
\hline Tomar posição & $\begin{array}{l}\text { Considero que, do meu ponto e vista, penso } \\
\text { que }\end{array}$ \\
\hline $\begin{array}{l}\text { Organizar } \\
\text { argumentos }\end{array}$ & $\begin{array}{l}\text { Inicialmente, primeiramente, em segundo } \\
\text { lugar, finalmente }\end{array}$ \\
\hline $\begin{array}{l}\text { Introduzir outras } \\
\text { vozes ou contra- } \\
\text { argumento }\end{array}$ & $\begin{array}{l}\text { Alguns dizem que, os especialistas afirmam } \\
\text { que, pesquisas apontam que }\end{array}$ \\
\hline $\begin{array}{l}\text { Indicar certeza } \\
\text { Indicar } \\
\text { possibilidade }\end{array}$ & $\begin{array}{l}\text { É evidente, sem dúvida, está claro, com } \\
\text { certeza, é indiscutível }\end{array}$ \\
\hline $\begin{array}{l}\text { Indicar causa ou } \\
\text { consequência }\end{array}$ & $\begin{array}{l}\text { Porque, provavelmente, me parece, é possível } \\
\text { consequentemente }\end{array}$ \\
\hline $\begin{array}{l}\text { Acrescentar } \\
\text { argumentos }\end{array}$ & Ainda, além de, também, por outro lado portanto, \\
\hline $\begin{array}{l}\text { Indicar oposição } \\
\text { Mas, porém, contudo, entretanto, embora, } \\
\text { apesar de }\end{array}$ \\
\hline $\begin{array}{l}\text { Introduzir } \\
\text { conclusão }\end{array}$ & Assim, por fim, logo, portanto \\
\hline
\end{tabular}

Quadro 13 - Articuladores textuais

O objetivo dessas atividades é instrumentalizar o aluno para utilizar esses recursos nas suas produções textuais. Ainda que esses mecanismos não sejam unicamente responsáveis pela argumentatividade, como nos lembra Koch (2011), 
alguns enunciados como por exemplo, o do texto argumentativo, têm como característica orientar o coenunciador ao raciocínio pretendido pelo enunciador, e isso pode ser concretizado com o que a autora chama de operadores argumentativos ou discursivos, denominados como articuladores textuais no material didático.

Outros exercícios foram propostos para que se refletisse a relação que um enunciado pode estabelecer com outro anterior.

\subsection{ATIVIDADES COMPLEMENTARES (MÓDULO 3)}

Concomitantemente às atividades do livro, apresentei a eles a proposta de se criar uma página no Facebook. Propus a criação de um grupo e alguns alunos sugeriram que fosse secreto. Expus então as condições de participação: o objetivo seria discutir temas polêmicos. Eles deveriam ler, comentar e seguir as orientações das postagens. Passamos uma lista para que eles anotassem seus endereços, assim criei a página e o grupo em minha casa.

Com alguns alunos já participantes, iniciamos as atividades do grupo em uma aula, na qual apresentei a página, lemos um texto que os exortava a colaborar e, em seguida, propus a discussão de textos referentes à realização da Copa do Mundo no Brasil.

Optamos por esse tema, porque tentávamos explorar a argumentação por meio do gênero comentário e, para isso, como aponta Geraldi (1991, p.137), para produzir um texto (em qualquer modalidade) é preciso que:

a) Se tenha o que dizer;

b) Se tenha uma razão para dizer o que se tem a dizer;

c) Se tenha para quem dizer o que se tem a dizer;

d) O locutor se constitua como tal, enquanto sujeito que diz o que diz para quem diz(ou, na imagem wittgensteiniana, seja um jogador no jogo);

e) Se escolham as estratégias para realizar (a), (b), (c) e (d)

Selecionamos, para transcrever aqui, algumas atividades propostas aos alunos na página do grupo:

$08 / 04 / 2014$ 
Este espaço está destinado a veicular a opinião dos leitores do grupo. Circularão textos de temas controversos e polêmicos. Você está livre para dar sua opinião, argumentar e defender sua posição em relação ao assunto tratado. Soltem o verbo!!!

$08 / 04 / 2014$

Pensar em opinião pública nos remete à ideia de grupo, de público, de opinião e de indivíduo. Segundo Sarah Chucid da Via, a "opinião é conjunto de crenças a respeito de temas controvertidos ou relacionados com interpretação valorativa ou o significado moral de certos fatos"....

08/04/2014

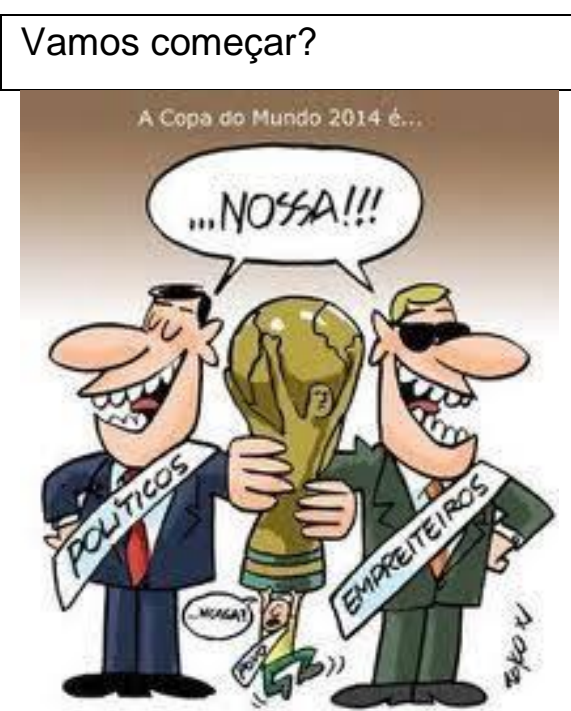

Fonte: Disponível em: http://www.jornal.ceiri.com.br/page/2/?s=copa. Acesso em 06/04/2014

Atividade coletiva:

Exibi as imagens e fomos debatendo o texto. Conforme os alunos iam participando, os comentários iam sendo digitados. Percebemos nessa atividade o caráter sintético das colocações e mais uma vez a concordância com o colega para evitar expor sua própria opinião.

Abaixo seguem as transcrições de alguns comentários; lembrando que as citações de Debate HT correspondem às intervenções da professora:

O povo não tem importância para os políticos porque não tem participação dos lucros da copa.

14 de abril às 09:20 
Além de haver muito roubo, estão gastando o dinheiro que poderia investir para ajudar a população.

14 de abril às 09:22

O superfaturamento das obras está dando lucros para os empreiteiros e prejudicando o povo.

14 de abril às 09:23 .

A publicação abaixo tem como objetivo comparar opiniões controversas a respeito do tema debatido no grupo. Entre as postagens, foi a que mais contou com a participação dos estudantes e também aquela em que eles mais exercitaram a argumentação. Por isso, a reproduzimos e teceremos algumas análises a respeito dos comentários postados pelos alunos.

15 de abril às $11: 31$

Quero ver a participação de todos.

Vale a pena o Brasil sediar a Copa de 2014?

Nosso país receberá os melhores jogadores do mundo para o que promete ser uma Copa do Mundo tão eletrizante quanto polêmica. O evento vai gerar empregos e obras de infraestrutura, mas também custará bilhões aos cofres públicos. Vai ser um golaço... ou bola fora?

\section{SIM}

Estima-se que o governo irá investir mais de 20 bilhões de reais em infraestrutura para receber a Copa de 2014. Somando os recursos diretos ou indiretos da iniciativa privada, o total deve chegar a 183 bilhões de reais. O dinheiro será distribuído em áreas como transportes, segurança e cultura, para que habitantes e turistas convivam em cidades mais confortáveis e funcionais

O Brasil passará a ter 12 estádios modernos, equiparáveis aos melhores do mundo, com mais comodidade e segurança para os torcedores. Na Alemanha, após a Copa de 2006, a frequência média nos estádios subiu para $90 \%$ da lotação. $E$ as arenas poderão atrair eventos como shows internacionais a estados como Mato Grosso, geralmente fora desse circuito

Pelo menos 600 mil estrangeiros devem visitar o país, número que pode ser ainda maior considerando as facilidades que nossos vizinhos sul-americanos têm para entrar aqui. Além disso, o fluxo de turismo nacional deve mover mais de 3 milhões de brasileiros. Quanto mais turistas, mais dinheiro entra para os cofres públicos na forma de impostos 
A previsão é que mais de 700 mil postos de trabalho sejam gerados, cerca de 330 mil empregos permanentes. Já há programas de capacitação de profissionais para atuar em várias áreas, da construção civil à hotelaria. O aquecimento da economia deverá impactar nosso Produto Interno Bruto (PIB) até 2014. No ano da Copa, o evento deve gerar cerca de $2 \%$ das receitas nacionais

\section{NÃO}

Temos um histórico de obras superfaturadas. A Vila do Pan-Americano do Rio, por exemplo, foi superfaturada em 1,8 milhão de reais, segundo relatório de 2009. Ricardo Teixeira, presidente da Confederação Brasileira de Futebol (CBF), já foi acusado pelo Ministério Público de lavagem de dinheiro e evasão de divisas. E ele também preside o Comitê Organizador da Copa de 2014

Ocupando a 73a posição mundial no Índice de Desenvolvimento Humano (IDH) e com quase $10 \%$ da população analfabeta, o Brasil poderia usar os 20 bilhões de reais a ser investidos na Copa para solucionar demandas mais urgentes, em áreas como educação e saúde pública. Com esse montante, seria possível, por exemplo, construir mais de 400 hospitaisescolas

Ainda há dúvidas sobre a capacidade do país de oferecer segurança aos turistas, aos atletas e à própria população. Os embates entre policiais e traficantes no Rio em novembro tiveram ampla repercussão negativa. Caso o país não seja capaz de garantir tempos de paz nas cidades-sedes, poderá queimar sua imagem no exterior e até perder o direito de realizar a Olimpíada de 2016

O enorme fluxo turístico poderá provocar um caos aéreo. Segundo a Infraero, das obras em 13 aeroportos considerados estratégicos para a Copa, seis não estarão concluídas até lá. Embora a estatal garanta que será possível atender à demanda, um estudo da Fundação Instituto de Pesquisas Econômicas (Fipe), da USP, diz que voos atrasados ou cancelados poderão chegar a 43,9\% em 2013

FONTES: Celso Unzelte, jornalista, pesquisador e apresentador do programa Loucos por Futebol (ESPN); Roberto Assaf, escritor e colunista do LANCE!; Ministério do Turismo; Ministério do Esporte; Comitê Organizador da Copa de 2014; Infraero; PNAD (Pesquisa Nacional por Amostra de Domicílios) 2010

Fonte: Disponível em: http://planetasustentavel.abril.com.br/noticia/desenvolvimento/vale-pena-brasilsediar-copa-2014-623510.shtml

Visualizado por 15

Pelo número de visualizações, percebemos que os alunos começaram a ler os textos, ainda que não tenham postados os comentários requeridos. Dado o contexto da turma, outra possibilidade era que apenas tenham visualizado e não tenham lido os 
textos veiculados. Ao verificar a página, constatamos que três alunos haviam escrito seus comentários.

J. R. e G. M. curtiram isso.

L. H. A. ham, só estou esperando a copa terminar para o nosso País acabar com está graça de tentar mostrar que ele é um belo País, pois eles só estão fazendo isto pq querem fazer bonito para os outros países lá de fora, em vez de usar todo este dinheiro em uma causa maior, não !, vai usar em uma coisa sem sentido, não entendo pq tanta importância em uma esporte assim, pois eles não dão a minima para a Saúde e Educação!....

29 de abril às $15: 13 \cdot$ Curtir · 1

Considerando o aspecto argumentativo, podemos afirmar que o estudante assume um posição diante do debate, mostrando-se indignado com os preparativos para a Copa do Mundo. Usa os operadores argumentativos "pois, porque, em vez de" para articular seu texto.

P. H. concordo com vc eles tentão agradar as pessoas lá de fora e esquece da população, tanto envestimento numa coisa que alguns anos sera esquecido por eles. Em vez de envestir em locais de saúde gastam dinhero atoa, mas quando a população pede um HOSPITAL demora mas de um ano para ser feito

29 de abril às 15:26 · Curtir · 1

Como não destacar o aspecto dialógico e responsivo da linguagem na teoria bakthiniana? O enunciador retoma o discurso do colega, acrescenta outros argumentos, como o aspecto descartável do investimento . Além disso, aponta solução para o destino do dinheiro público e usa de recursos gráficos como o termo HOSPITAL, em caixa alta, para destacar a carência na área da saúde.

K. A. Não, o Brasil sediar a copa e um puro roubo, eu particularmente, não tenho orgulho em falar "sou brasileiro" pois como eu terei orgulho de um país como esse? Roubo, corrupção, penso o mesmo que L. e P., pois tem muita, muita coisa que necessitava de ajuda, o problema, e que se uma pessoa contribui com "Criança Esperança, Teleton" ela é mais roubada, pois se tem tanto dinheiro para fazer estádios, contratar mão de obra, e tudo, poderiam bem ajudar os pobres, os deficientes, porem não ajudam, o problema ta na sociedade que é tola, e nos políticos, que são muito, muito inteligentes, o Brasil precisa tomar partido, pois se não, mais ruína e problemas virão, o interessante e que eu já testemunhei, professores que tentavam implantar nas cabeças dos alunos que o governo dava tudo de bom grado, por isso me espanto... 
Esse aluno, mostra-se mais politizado, posiciona-se criticamente em relação não só ao evento da Copa do Mundo, mas também aos desdobramentos sociais que envolve o sistema político do país.

29 de abril às $15: 48 \cdot$ Curtir $\cdot 1$

Debate HT Onde estão os outros alunos? Vamos participar, galera!

Como os demais alunos não participavam, reservei o datashow e projetei os textos para serem lidos na sala. Ainda assim, não houve respostas. Na aula seguinte, reservei a sala de informática e os levei para produzirem os textos abaixo transcritos.

5 de maio às $20: 21 \cdot$ Curtir $\cdot 1$

J. R. Não, é puro desperdício de dinheiro, alguns estádios depois vão ficar parados, e não serviram para nada, com tanta coisa pra investir nosso dinheiro, e eles ficam investindo em bobeira, ta certo $q$ trouxe alguns empregos e tudo mais, só que aposto q fosse pra investir em alguma coisa do nosso interesse tipo escolas novas ou outras coisas eles iriam reclamar, é o cumulo esse "Brasil" puro roubo , tenho vergonha desse brasil, e concordo com o K. se tem tanto dinheiro pra fazer a copa, pq nao pra ajudar o proximo, afinal o dinheiro é nosso mesmo!

8 de maio às $21: 36 \cdot$ Curtir $\cdot 1$

Neste comentário, temos além da interação com o texto dos colegas, uma contra-argumentação "ta certo q trouxe alguns empregos e tudo mais", assumindo, assim, a existência de outras vozes e, ao mesmo tempo, retomando sua posição.

Debate HT Vocês poderiam reler o texto do sim e justificar por que aqueles que acreditam nos benefícios da Copa não têm razão.

11 de maio às 21:26 · Curtir

V. A. Acho que o Brasil nao está pronto para sediar a copa agora porque estao gastando milhões de reias em estadios , ao inves de investirem em mais educação, saúde , etc..

12 de maio às $22: 22 \cdot$ Curtir $\cdot 3$

V. A. concordo com a J. , é muito desperdício de dinheiro...

13 de maio às $11: 03 \cdot$ Curtir $\cdot 1$

G. M. Não, acho que o brasil nao esta pronto ainda para sediar a copa agora, acho que estao gastando milhoes de reais em estadios, ao inves de investirem em mais educaçao, 
saude, porque é o maximo que devem fazer por nois, concordo com a V. e J. e muito desperdicio mesmo ...

13 de maio às 11:06 · Editado $\cdot$ Curtir $\cdot 1$

B. R. nao,o brasil nao tem estrutura para sediar a copa com tanta coisa pra investir nosso dinheiro e eles gastando com bobeiras realmente concordo com a j.!

13 de maio às $11: 09 \cdot$ Curtir $\cdot 2$

S. M. concordo com a j. q alguns estadios parados e sera muito disperdicio de dinheiro enves de envestir nos postos de salde ou escolas e etc sara e franciellen...

13 de maio às $11: 14 \cdot$ Curtir $\cdot 2$

J. R.S.J. R. Não, Nossa nem tenho o que falar a joyce disse tudoo,, maiis é a realidade,, povoo burro essa tal de DILMA!! uma IDIOTA!! ta certo muitas pessoas gostaam de futebol e tal maiis praa que sediar a copa logo agora!! tantoode coisas para serem feitaa eem hospitaiss tantaas pessoas quereendoo alguum transplantee!! isso aii vaai seer sóo alguns dias de curtiçãoo maiis e a saudadee doos outrooss como que ficaa??/ nossa eeu de veerdade nãoo tenho nem um pingoo de orgulho de dizer que eu sou brasileiraa!! que paiis horrivel que nois vivee

14 de maio às 10:58 · Editado $\cdot$ Curtir

Com exceção do último comentário, temos paráfrases dos demais e pouco acréscimo ao debate. Entretanto, podemos concluir que quando o aluno tem o que dizer, ou quando o assunto é de relevância e próximo a eles, a argumentação tornase um instrumento de cidadania.

\subsection{DESCRIÇÃO DO MÓDULO 4: LEITURAS DE GÊNEROS ARGUMENTATIVOS}

Neste módulo, desenvolvemos as atividades propostas no caderno do aluno, com as orientações dadas no caderno do professor, ou seja, desenvolvemos a SITUAÇÃO DE APRENDIZAGEM 2, cujo título é TRAÇOS CARACTERÍSTICOS DO AGRUPAMENTO TIPOLÓGICO “ARGUMENTAR”

Revendo as atividades como um todo, talvez, hoje, começássemos por esse material e, em seguida, faríamos as atividades propostas anteriormente, focando a sequência didática na produção textual e no estudo do gênero escolhido. A preocupação em oferecer ao aluno o maior número de informação e prepará-lo adequadamente para o objetivo do projeto pode pôr em risco a própria sequência, 
ou, nas palavras de Schneuwly e Dolz(2004), tornar a sequência ingerenciável. Contudo, os termos "agrupamento tipológico" e a variedade de gêneros trabalhados na unidade poderiam confundir mais do que auxiliar à compreensão dos estudantes sobre o gênero argumentativo-artigo de opinião.

\subsubsection{LEITURA E ANÁLISE DE TEXTOS ARGUMENTATIVOS}

Antes da leitura, comentamos sobre o assunto violência e discutimos em quais letras de música poderíamos encontrar esse tema. Alguns citaram letras de funk e de rap que conheciam.

Embora o material recomendasse a leitura silenciosa, dado o contexto da sala de aula, começamos a aula combinando de fazer a leitura do texto de forma compartilhada. Como o texto era sugestivo, "Segurança", de Luis Fernando Veríssimo, não fiz muitas perguntas e logo iniciamos a leitura.

\section{Leitura e análise de texto}

1. Faça uma leitura silenciosa da crônica a seguir.

\section{Crônica}

Segurança

O ponto de venda mais forte do condomínio era a sua segurança. Havia as belas casas,os jardins, os playgrounds, as piscinas, mas havia, acima de tudo, segurança. Toda a área era cercada por um muro alto. Havia um portão principal com guardas que controlavam tudo por um circuito fechado de TV. Só entravam no condomínio os proprietários e visitantes devidamente identificados e crachados.

Mas os assaltos começaram assim mesmo. Ladrões pulavam os muros e assaltavam as casas. Os condôminos decidiram colocar torres com guardas ao longo do muro alto. Nos quatros lados.

As inspeções tornaram-se mais rigorosas no portão de entrada. Agora não só os visitantes eram obrigados a usar crachá. Os proprietários e seus familiares também. Não passava ninguém pelo portão sem se identificar para a guarda. Nem as babás. Nem os bebês. Mas os assaltos continuaram.

Decidiram eletrificar os muros. Houve protestos, mas no fim todos concordaram. O mais importante era a segurança. Quem tocasse no fio de alta tensão em cima do muro morreria eletrocutado. Se não morresse, atrairia para o local um batalhão de guardas com ordens de atirar para matar.

Grades nas janelas de todas as casas. Era o jeito. Mesmo se os ladrões ultrapassassem os altos muros, e o fio de alta tensão, e as patrulhas, e os cachorros, e a segunda cerca, de arame farpado, erguida dentro do perímetro, não conseguiriam entrar nas casas. Todas as janelas gradeadas.

Mas os assaltos continuaram.

Foi feito um apelo para que as pessoas saíssem de casa o mínimo possível. Dois assaltantes tinham entrado no condomínio no banco de trás do carro de um proprietário, com 
um revólver apontado para a sua nuca. Assaltaram a casa, depois saíram no carro roubado, com crachás roubados. Além do controle das entradas, passou a ser feito um rigoroso controle das saídas. Para sair, só com um exame demorado do crachá e com autorização expressa da guarda, que não queria conversa nem aceitava suborno.

Mas os assaltos continuaram.

Foi reforçada a guarda. Construíram uma terceira cerca. As famílias de mais posses, com mais coisas para serem roubadas, mudaram-se para uma chamada área de segurança máxima. E foi tomada uma medida extrema. Ninguém pode entrar no condomínio. Ninguém. Visitas, só num local predeterminado pela guarda, sob sua severa vigilância e por curtos períodos. E ninguém pode sair.

Agora a segurança é completa. Não tem havido mais assaltos. Ninguém precisa temer pelo seu patrimônio.

Os ladrões que passam pela calçada só conseguem espiar através do grande portão de ferro e talvez avistar um ou outro condômino agarrado às grades da sua casa, olhando melancolicamente para a rua.

Mas surgiu outro problema.

As tentativas de fuga. E há motins constantes de condôminos que tentam de qualquer maneira atingir a liberdade. A guarda tem sido obrigada a agir com energia.

VERISSIMO, Luis Fernando. In:___. Comédias para se ler na escola.

Rio de Janeiro: Objetiva, 2002. p. 97. (C) by Luis Fernando Verissimo.

Quadro 14 - Atividade do Caderno do aluno, 9ํano. Vol 1, SÃO PAULO, 2014, p.16

Tratava-se de uma crônica e fiz a leitura reforçando a entonação para garantir o suspense. Durante a leitura, já houve comentários "Era prisão? " "Presídio? ", indignação de uns e surpresa de outros. A cada parágrafo fazia uma pausa, mas eles não queriam ficar respondendo, queriam que terminasse logo o texto. Após a leitura, discutimos sobre a possibilidade de ser verdade o que o texto trazia. Comparamos o bairro e as casas do centro quanto à estrutura. Eles apontaram que havia grades e muros altos nas casas do centro, mas em seu bairro nem todas tinham esse reforço. Houve relatos de alguns que tiveram a casa invadida. Outros comentaram que ninguém seria louco de entrar em suas casas. Perguntei o porquê, houve muitos risos. Eles têm o hábito de se autoacusarem pela atuação no tráfico, havendo um código para não serem perturbados. Nunca se sabe quando é brincadeira ou fato.

Das atividades solicitadas no caderno do aluno, pedi para que somente fizessem um comentário a respeito da crônica, que dessem suas impressões sobre o texto, o assunto e como foi abordado. Em seguida, fizemos a leitura da charge de Laerte: 

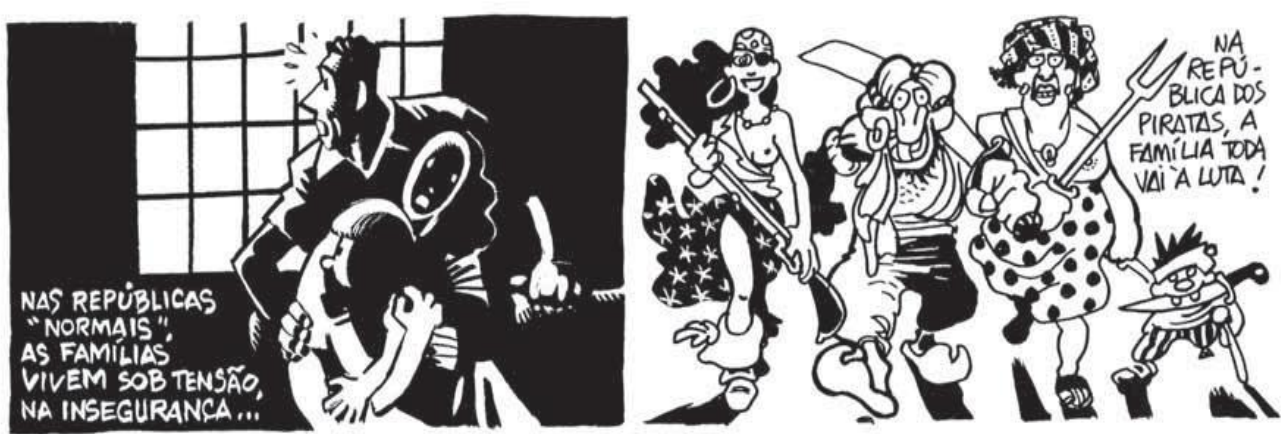

Figura 10 - Fonte: Caderno do aluno, 9aano, vol.1,SÃO PAULO, 2014-2017, p.17.

Discutimos os recursos empregados pelo autor, tais como: o jogo de claro e escuro, os dois lados da sociedade, as expressões no rosto das personagens, a grade separando as famílias e a relação da imagem com a crônica lida. Os alunos também preencheram o quadro-síntese abaixo. Desta vez, foram agrupados em duplas e iam me chamando para ajudá-los a responder. A maioria fez a atividade sem grandes dificuldades.

\begin{tabular}{|c|c|}
\hline 1. Quem são os autores dos textos lidos? & \\
\hline $\begin{array}{l}\text { 2. Em que momento os textos revelam o } \\
\text { ponto de vista desses autores em } \\
\text { relação ao tema? A opinião deles sobre o } \\
\text { tema } \\
\text { converge ou diverge? }\end{array}$ & \\
\hline $\begin{array}{l}\text { 3. Que argumentos eles utilizam para } \\
\text { sustentar essa opinião? }\end{array}$ & \\
\hline $\begin{array}{l}\text { 4. Qual dos textos, em sua opinião, } \\
\text { deixa mais claro o tema que está sendo } \\
\text { discutido? Por quê? }\end{array}$ & \\
\hline $\begin{array}{l}\text { 5. Se fossem escrever sobre o tema } \\
\text { "violência", qual gênero vocês } \\
\text { escolheriam? Por quê? }\end{array}$ & \\
\hline $\begin{array}{l}\text { 6. Se os textos fossem considerados } \\
\text { isoladamente, vocês teriam a mesma } \\
\text { compreensão do tema e da opinião dos } \\
\text { autores? }\end{array}$ & \\
\hline
\end{tabular}

\subsection{DESCRIÇÃO DO MÓDULO 5: ATIVIDADE COM ARTIGO DE OPINIÃO}


A exposição ao gênero é uma das maneiras de se familiarizar com os seus aspectos linguísticos-composicionais; por isso, trazer textos que circularam efetivamente na sociedade, ainda que não seja no seu portador, colabora para que o aluno perceba que não há uma única forma de escrever. Concordamos com Koch,(2011, p.27) no sentido de que

Não basta conhecer o significado literal das palavras ou sentenças de uma língua: é preciso saber reconhecer todos os seus empregos possíveis, que podem variar de acordo com as intenções do falante e as circunstâncias de sua produção.

Com o objetivo de retomar as características do gênero artigo de opinião, selecionei o texto abaixo e propus as atividades descritas. Não fizemos a leitura coletiva, apenas destaquei as referências do texto. Solicitei também que entregassem as respostas em folha separada para que pudesse diagnosticar a aprendizagem até o momento da atividade.

\section{SOU CONTRA A REDUÇÃO DA MAIORIDADE PENAL Renato Roseno}

A brutalidade cometida contra dois jovens em São Paulo reacendeu uma fogueira: a redução da idade penal. Algumas pessoas defendem a ideia de que a partir dos dezesseis anos os jovens que cometem crimes devem cumprir pena em prisão. Acreditam que a violência pode estar aumentando porque as penas que estão previstas em lei, ou a aplicação delas, são muito suaves para os menores de idade. Mas é necessário pensar nos porquês da violência, já que não há um único tipo de crime.

Vivemos em um sistema socioeconômico historicamente desigual e violento, que só pode gerar mais violência. Então, medidas mais repressivas nos dão a falsa sensação de que algo está sendo feito, mas o problema só piora. Por isso, temos que fazer as opções mais eficientes e mais condizentes com os valores que defendemos.

Defendo uma sociedade que cometa menos crimes e não que puna mais. Em nenhum lugar do mundo houve experiência positiva de adolescentes e adultos juntos no mesmo sistema penal. Fazer isso não diminuirá a violência. Nosso sistema penal como está não melhora as pessoas. O problema não está só na lei, mas na capacidade para aplicá-la.

Sou contra porque a possibilidade de sobrevivência e transformação desses adolescentes está na correta aplicação do Estatuto da Criança e do Adolescente (ECA). Lá estão previstas seis medidas diferentes para a responsabilização de adolescentes que violaram a lei. Para fazer bom uso do ECA é necessário dinheiro, competência e vontade. 
Sou contra toda e qualquer forma de impunidade. Quem fere a lei deve ser responsabilizado. Mas reduzir a idade penal é ineficiente para atacar o problema. Problemas complexos não serão superados de modo simplório e imediatista. Precisamos de inteligência, orçamento e, sobretudo, de um projeto ético e político de sociedade que valorize a vida em todas as suas formas. Nossos jovens não precisam ir para a cadeia. Precisam sair do caminho que os leva até lá. A decisão agora é nossa: se queremos construir um país com mais prisões ou com mais parques e escolas.

Renato Roseano é advogado, coordenador do Centro De Defesa da Criança e do Adolescente (Cedeca -

Ceará) e da Associação Nacional dos Centros de Defesa da Criança e do Adolescente (Anced).

Fonte: www.cedecaceara.org/maioridadena.htm

\section{Atividade}

Ler novamente o texto e responder as questões a seguir:

a) Quem é o autor do texto? Em que ele é especialista?

b) Onde o texto foi publicado?

c) Qual é a questão polêmica?

d) $\mathrm{O}$ autor refere-se a um acontecimento que o levou a escrever esse artigo. Que acontecimento foi esse?

e) Qual a posição do autor a respeito da polêmica?

f) Que argumentos ele usa para justificar sua posição?

g) No texto, o autor apresenta argumentos de pessoas que discordam dele. Que argumentos são esses?

h) $\mathrm{O}$ autor propõe alguma alternativa de tratamento para os jovens infratores, ou seja, reflete a respeito de uma solução para a polêmica?

i) Qual o objetivo do autor?

j) Quem é o público leitor?

Os alunos apresentaram maior dificuldade em responder ao item $f$ e $g$, provavelmente porque demandava uma leitura global do texto e um processo de inferência com o qual eles ainda não têm grande experiência. A maioria retirou apenas um argumento e confundiu a contra-argumentação com a antítese. Alguns alunos só responderam aos primeiros itens e desistiram de fazer a atividade. Infelizmente há um grupo de alunos que não tem habilidade de ler e compreender 
enunciados. Em algumas aulas conto com uma professora auxiliar, mas isso ocorre em todas as aulas e alguns alunos se recusam a serem ajudados.

\subsubsection{ATIVIDADE COM JORNAL}

Levei para sala vários jornais (a escola recebe o jornal O Estado de S. Paulo com alguma frequência) e pedi que pesquisassem na seção Opinião textos que abordassem o tema da Copa do Mundo no Brasil. Eles deveriam localizar o nome do autor, título e a opinião do autor. Ao final da aula, fizemos um debate sobre as posições encontradas no jornal; perguntei-lhes se prevaleciam argumentos favoráveis ou contrários ao evento. Houve algumas manifestações, alguns concordavam com aqueles que se mostravam contrários, pois a maioria tem demonstrado insatisfação quanto à organização da realização da Copa do Mundo e houve muitas críticas quanto às ações governamentais.

\section{Produção de texto}

Como na avaliação bimestral havia necessidade de se produzir um texto, mesmo não terminando as atividades previstas na SD, foi necessário solicitar a eles um artigo de opinião. Decidimos buscar uma proposta cujo tema abordasse os textos discutidos em classe e analisados na internet.

\subsection{DESCRIÇÃO E ANÁLISE DE PRODUÇÃO TEXTUAL - AVALIAÇÃO BIMESTRAL}

$\mathrm{Na}$ sequência das atividades, no dia 03 do mês de junho, foi preciso propor uma produção escrita para todas as turmas da escola, pois o calendário escolar foi adaptado ao início dos jogos da Copa do Mundo e a semana de provas ocorreria antes do evento. Como já havíamos pesquisado e debatido sobre esse tema com a turma do $9^{\circ}$ ano, procuramos uma proposta que atendesse às nossas expectativas e valorizasse os conhecimentos formulados pelos alunos. Em nossas pesquisas, 
encontramos o site da UOL. Nele, há uma página destinada a um banco de redações, no qual os internautas podem ler propostas, enviar seus textos para serem avaliados, assim como ler outras redações analisadas. A temática do referido site, para o mês de abril, mostrou-se adequada aos nossos propósitos; sendo assim, fizemos algumas adaptações e propusemos o seguinte para nossos alunos:

Leia atentamente os textos e as orientações, antes de escrever seu texto.

\section{Qual será o legado da Copa do Mundo para o Brasil?}

"A Copa será uma grande oportunidade para acelerar o crescimento e fundamental para o desenvolvimento do nosso Brasil", disse, em 2010, o então presidente Luiz Inácio Lula da Silva, dando o tom da grande expectativa sobre o papel que o torneio poderia ter no país. De lá para cá, muito se falou e tem se falado sobre o que a Copa do Mundo iria legar ou deixar ao Brasil, como você pode ver pelos textos apresentados na coletânea a seguir, que trazem reflexões diferentes sobre o que se poderia chamar de "o legado da Copa". Isso sem falar nos que não acreditam em nenhum legado e protestam contra os gastos para a realização do campeonato. Considerando os textos abaixo, bem como seus próprios conhecimentos sobre o assunto, produza um texto dissertativo-argumentativo apresentando qual, em seu ponto de vista, será o legado que o Brasil vai receber com esse evento esportivo

\section{Reta final}

A menos de cinco meses da Copa do Mundo, o Brasil entra na reta final dos preparativos. Apesar de não ter desenvolvido um plano de infraestrutura capaz de beneficiar todas as cidades-sede da forma como parte da população esperava, haverá ganhos segundo as avaliações do Sindicato Nacional da Arquitetura e da Engenharia (Sinaenco) e do Ministério do Esporte.

Para o governo federal, até a frustração com os legados das obras resultaram em algo positivo, já que as manifestações ocorridas durante a Copa das Confederações foram apontadas como a retomada do exercício de cidadania pelos brasileiros.

"Essas manifestações fizeram da mobilidade urbana a pauta da década e o grande desafio para dar qualidade de vida às cidades brasileiras. E isso já chegou [aos ouvidos] do governo federal", disse à Agência Brasil o vice-presidente do Sinaenco, João Alberto Viol. Ele acrescentou que a decisão de fazer a Copa do Mundo no Brasil, possibilitou a discussão dos problemas do país.

\section{[Agência Brasil]}

\section{Escolas e hospitais}


"A Copa será uma grande oportunidade para acelerar o crescimento e fundamental para o desenvolvimento do nosso Brasil", disse, em 2010, o então presidente Luiz Inácio Lula da Silva, dando o tom da grande expectativa sobre o papel que o torneio em junho/julho de 2014 poderia ter no país.

Mas a visão de que o evento possa estimular o crescimento ou o desenvolvimento de um país é questionada pelos autores de um livro que analisa o futebol em números e fala sobre o impacto de grandes eventos esportivos sobre a economia de nações que as sediaram.

"A ideia de que a Copa vai impulsionar a economia é um mito", disse à BBC Brasil o jornalista britânico Simon Kuper, autor de Soccernomics, escrito em parceria com o economista britânico Stefan Szymanski.

"Sediar uma Copa do Mundo não traz nenhum legado econômico. Se você quer impulsionar a economia com o dinheiro do povo, que paga impostos, é melhor investir em escolas e hospitais", disse Kuper.

[BBC Brasil]

\section{Copa das Copas}

No Ministério do Esporte, há uma percepção de que as seguidas críticas sofridas pelo Mundial são responsáveis pela queda na aprovação [da Copa pela população brasileira], embora se ressalte que a maioria ainda apoia o evento. Ainda há uma aposta de que o quadro pode ser revertido com obras entregues próximo ao evento.

Só que a presidente da República, Dilma Rousseff, já abandonou o discurso de legado da Copa. Na segunda-feira, não conectou o Mundial ao desenvolvimento, concentrando-se em alegria e esporte.

"Eu queria dizer para vocês que a Copa não será apenas um evento esportivo. Será um evento esportivo, sim, esse é o principal aspecto da Copa, mas também é uma oportunidade do Brasil se mostrar ao mundo, mostrar a força e a vitalidade da nação brasileira", afirmou ela, que chama o evento de Copa das Copas".

\section{[Blog do Rodrigo Mattos]}

Fonte: Adaptado de http://educacao.uol.com.br/bancoderedacoes/qual-sera-o-legado-dacopa-do-mundo-para-o-brasil.jhtm. Acesso em 24/05/2014

Com base nos textos de apoio, nas pesquisas realizadas em sala e na sala de informática, nos seus conhecimentos sobre o assunto, escreva um artigo de opinião sobre o seguinte tema:

O que o evento da Copa deixará para o Brasil, depois da Copa?

\section{Observações}

Não deve estar redigido sob a forma de poema (versos) ou narração;

A redação deve ter no mínimo 15 e no máximo 30 linhas escritas; 
Não deixe de dar um título à sua redação.

No total, 24 alunos fizeram a avaliação. Destes, 12 escreveram textos com quinze linhas ou mais e se posicionaram em relação ao tema. Outros 6 estudantes produziram comentários opinativos com menos de dez linhas. Tivemos dois textos com reprodução integral de trechos do texto de apoio, três avaliações em branco e um texto com palavras ilegíveis.

Como nosso objetivo é verificar o processo de ensino/aprendizagem de gêneros argumentativos, trouxemos para análise cinco produções dos estudantes que mais se destacaram durante o desenvolvimento das atividades e produziram textos próximos ao gênero estudado. Três deles já tiveram as produções analisadas nos capítulos anteriores e os outros dois, apesar de não terem sido citados, consideramos pertinente fazer a análise de seus textos nas duas situações finais.

Nossa análise não tem a pretensão de esgotar todas as possibilidades, mas, dentro de uma perspectiva enunciativa, verificar alguns pontos como: em que medida os alunos se beneficiaram das atividades propostas; como o enunciado é construído pelo estudante em seus aspectos temáticos e composicionais, relativos ao gênero artigo de opinião e qual a influência do contexto de produção nos enunciados produzidos por eles.

\section{A copa no Brasil}

A copa está chegando e devemos todos ter um bom comportamento para que nosso país não fique mal falado, quando o país disse que iria sediar a Copa ninguém se manifestou agora querem protestar! Só acho que tá bem tarde para isso. Não sou contra e muito menos a favor a burrada já está feita agora já era!

Por que penso assim? Porque é desperdício do nosso dinheiro, se fosse para melhorias, eles não iriam querer gastar isso tudo.

Cada um tem sua opinião e trará dinheiro para o Brasil, porém muito pouco, talvez nem metade dos gastos.

Talvez será até um bom evento.

O que deve ser feito? Torcermos para que o Brasil ganhe para compensar o dinheiro gasto, e assim a população irá se conformar um pouco.

Devemos evitar a violência e crimes pois o Brasil irá tar muito lotado pra se preocupar com isso!

J.R.B.S

${ }^{4}$ Anexo B- Texto 1

4 Decidimos disponibilizar apenas os textos finais em anexo, pois as primeiras produções sofreram revisões no próprio texto, trazendo prejuízos para sua leitura. 
Fica evidente que a aluna procurou seguir algumas orientações quanto ao caráter formal do gênero, pois distribuiu seu texto em parágrafos, seguindo os esquemas de planejamento estudados durante as aulas. No entanto, as atividades nas quais discutimos sobre a posição que o autor deve defender para convencer seu leitor não ficaram evidenciadas.

Em um sentido global, aparentemente ela é contra a realização do evento, pois utiliza-se de expressões como "a burrada já está feita", "é desperdício de dinheiro", mas não consegue assumir uma posição definida, contradizendo-se com expressões como "não sou contra e muito menos a favor" e "Talvez será até um bom evento". Não segue, portanto, as orientações dadas em como compor a argumentação, sustentando-a com argumentos convincentes. Usa alguns operadores argumentativos (porque, mas, porém, pois), ou seja, apenas aqueles que já eram empregados por eles antes do desenvolvimento das atividades. Quanto ao tema, percebem-se reflexos de enunciados colhidos durante as atividades de preparação. Por exemplo: "quando o país disse que iria sediar a Copa ninguém se manifestou agora querem protestar"; esse ponto foi discutido, na sala, após termos lidos notícias sobre a copa e a relação do evento com as manifestações que ilustravam todos os jornais da época.

O segundo parágrafo retoma a postagem da mesma aluna na página do facebook e transcrita anteriormente“...é puro desperdício de dinheiro, alguns estádios depois vão ficar parados... se fosse pra investir em alguma coisa do nosso interesse tipo escolas novas ou outras coisa eles iriam reclamar". Nota-se também que não houve uma adequação da linguagem. A linguagem utilizada no artigo se aproxima muito da coloquialidade, característica do ambiente virtual, menos na questão do uso de abreviações, característicos dessa esfera de comunicação.

Lembranças de uma copa

Depois que acabarem com a palhaçada da copa, iremos voltar para um país onde a desigualdade e violência dominam.

Mas quando estiver na hora em que o nosso país largar a mão de bobeiras como a copa, iremos nos aprimorar juntos para criarmos um país melhor, até sermos um país de primeiro mundo não desistiremos de nossos sonhos, e assim teremos a capacidade de nos unirmos para comemorarmos uma coisa realmente importante para todos nós, um Brasil com igualdade e melhorias para todos, um lugar que não haja violência, brigas, racismo, buling, e assim vai, aí poderemos dizer que temos um grande orgulho de sermos Brasileiros! 
De acordo com o texto, minha opinião é esta: Em quanto não houver brasileiros com um amplo conhecimento, não poderemos nos unir por uma causa justa. E muitas pessoas não tem a capacidade de pensar o que possa estar acontecendo pelas suas costas, e a sim poderam ser enganados facilmente.

Agora estão acontecendo muitos protestos por várias causas injustas, e a sim vários brasileiros que não se deixam enganar por qualquer coisa, e estão lutando pelos seus direitos.

A minha opinião sobre este conceito é que deveríamos nos juntar e fazer um protesto para um Brasil melhor, em que a já uma segurança mais ampla, um salário justo para todos, uma convivência melhor entre nós, sem nenhum preconceito e nenhuma injustiça, esta é minha visão de um país melhor, em que todos poderemos nos unir contra uma causa nobre e justa para todos, e dizer com muito orgulho, eu sou Brasileiro!

L.H.A.C.

Anexo B - Texto 2

Observarmos que este estudante tem opinião formada sobre questões políticas, mas ele não seguiu as orientações ao planejar o texto, utilizando uma linguagem mais formal, utilizando-se de expressões bastante coloquiais: "palhaçada", " e assim vai", "aí".

No primeiro parágrafo emite sua opinião a respeito do tema, mas na sequência discorre sobre as manifestações ocorridas por todo o país e que foram amplamente divulgadas pela imprensa escrita e televisiva. Não percebemos a aprendizagem da forma composicional do gênero que foi discutida em sala, ou seja, deveria organizar o texto, apresentando uma questão a ser discutida, posicionar-se diante do tema, justificar seu posicionamento com argumentos convincentes e propor uma intervenção.

O autor assume um papel social, identificando-se com alguns manifestantes, como por exemplo, "vários brasileiros que não se deixam enganar por qualquer coisa”. Talvez, o autor esteja tentando argumentar com aqueles que estão a favor do evento, mas não explicita essa ideia em seu texto.

Há, nesta produção também uma atitude responsiva em relação aos jornais levados para a sala e aos textos apresentados no ambiente virtual, pois as manchetes e o foco das matérias sempre recaíam sobre as manifestações populares.

O não desenvolvimento das ideias e a menção a textos trabalhados em aula ("De acordo com o texto") devem ter ocorrido por considerar como interlocutor o professor ou os demais alunos, ou seja, para o autor não seria necessário explicitar o conteúdo e o texto mencionado, pois eles já são de conhecimento dos leitores em 
questão. É comum, em atividades escolares, o aluno colocar o título ou o tema e começar o texto sem fazer alusão ao assunto tratado, ou, em outras atividades, responder sucintamente, sem elaborar uma frase ou enunciado, apenas utilizandose de palavras-chave.

Brasil um país para todos "fazer" bagunça

Brasil o sediador da copa de 2014, um país tropical, a casa do futebol Menos de 20 dias para a copa e ainda nem os estádios(nem o país) foram construídos. Quando a festa estiver rolando imagine quantos roubos e caos estará acontecendo, e isso é bom, claro que não isso e ridículo.

Sou extremamente contra, o Brasil só vai mostrar mais o quão despreparado é o país, num país onde na emissora famosa que em um programa faz homenagem a um homem libertino, e sem vergonha, o homenageam por ter 25 filhos, então se gringo vê isso pensa "lá eu viro, lá eu pego uma mulher", e o nosso instrumento a droga de um chocalho, as músicas da copa do Brasil são cantadas em outro idioma, po (...) e outros, então o Brasil tem todo zoado e não está preparado para isso.

Por que sou contra:

. os equipamentos, estádios e aeroportos não estão preparados . odeio esportes

- a cultura do Brasil é mostrada por corpos e chocalhos

. E sejamos verdadeiros....os gringos e os nativos querem fazer bagunça e zoação.

. E falta construir um país

Eu sugiro que pare e cancele, só assim resolverá, assim sendo adiado para que o Brasil saia do poço. Mas também funciona protestar e quebrar tudo só assim causa impacto, pois traumatiza.

Algo impossível é revolução sem violência e caos, perderemos coisas mas é o sacrifício, para um (...) um país, um mundo melhor!!!

\section{K.A.A}

Obs: o aluno encerrou seu texto fazendo apologia à violência, mesmo sendo orientado a substituir os termos, recusou-se a fazê-lo.

Anexo B- Texto 3

O autor não demonstra ter utilizado os recursos estudados durante a preparação para produção do artigo de opinião. Talvez tenha ficado para este e para os demais alunos, uma falsa ideia de que o gênero se resume em dar uma opinião e justificá-la com informações. Essa compreensão pode ter sido causada por algumas atividades que requeriam identificar a opinião do autor e os argumentos que comprovavam sua posição.

Há uma fuga do tema proposto, pois o estudante se posiciona contra a realização da Copa do Mundo. Essa não era a questão principal a ser debatida e sim, qual seria o legado do evento. Percebe-se que o autor defende seu ponto de vista de maneira enfática, usando expressões coloquiais ("rolando", "sem vergonha", 
"droga de chocalho", "zoado"...) alternadas com construções mais formais (" o quão despreparado", "o homenageiam"), provavelmente com a intenção de chocar o leitor, contrariando-se assim, a premissa teórica da argumentação em que o enunciador deve buscar a adesão do interlocutor para convencê-lo (PERELMAN \& OLBRECHTS-TYTECA, 1996)

Ainda quanto à composição textual, ele inicia o texto, organizando-o em parágrafos, com inadequações quanto à delimitação das frases dentro deste, como por exemplo, no segundo parágrafo, composto por apenas um período: "Sou extremamente contra, o Brasil só vai mostrar mais o quão despreparado é o país,[.] num país onde na emissora famosa que em um programa faz homenagem a um homem libertino, e sem vergonha, o homenageiam por ter 25 filhos, então se gringo vê isso pensa "lá eu viro, lá eu pego uma mulher",[.] e o nosso instrumento a droga de um chocalho, as músicas da copa do Brasil são cantadas em outro idioma, po (...) e outros,[.] então o Brasil tem todo zoado e não está preparado para isso." Em seguida, opta por fazer tópicos para justificar seu ponto de vista, sem, contudo, ampliar as ideias formuladas. Não vemos, também, uso dos articuladores argumentativos estudados; falta coesão, tanto no interior do parágrafo, quanto no enunciado global. Por exemplo, o segundo parágrafo inicia-se com a expressão "sou extremamente contra", mas não conclui o enunciado e logo caracteriza o país como sendo um lugar com muitos problemas. Descreve uma sequência de situações, utilizando orações justapostas, sem empregar elementos coesivos.

$\mathrm{O}$ aluno encerra o texto, retomando as discussões e leituras realizadas durante as atividades de preparação, ou seja, as manifestações populares, desencadeadas no país na época que antecedia à Copa Mundial. As informações dadas nos textos de apoio e a resposta à proposta foram substituídas por enunciados veiculados durante os debates em sala e a participação no ambiente virtual; por exemplo, conforme transcrito anteriormente, no dia 29 de abril, em resposta ao texto publicado sobre quem apoiava ou não a Copa do mundo, o estudante postou "Não, o Brasil sediar a copa e um puro roubo, eu particularmente, não tenho orgulho em falar "sou brasileiro" pois como eu terei orgulho de um país como esse? Roubo, corrupção...".

Fifa 2014 
Eu acho que a copa no Brasil está sendo legal acho bacana, sim claro gastaram muito dinheiro mais de 20 milhões em estádios aeroportos, etc... Sendo que eles podiam investir em escolas, saúde, ônibus, metrôs. A copa não será apenas um evento esportivo, mas claro será um evento esportivo, é uma oportunidade do Brasil mostrar ao mundo, mostrar força e vitalidade da nação brasileira.

Eu concordo com o Brasil

- a copa será uma grande oportunidade para acelerar o crescimento e fundamental para o desenvolvimento do nosso Brasil.

Acho ridículo essas manifestações que as pessoas estão fazendo pra que isso agora já é tarde já gastaram o dinheiro não tem como voltar mais atrais, vai quebrar as coisa a toa porque eles vão arrumar com o nosso dinheiro "dinheiro do imposto"

Algumas pessoas brasileiras tem que entender que o Brasil vai ganhar.

Deve ser feito uma manifestação direito já que querem fazer só não destruindo mais nada. Mais tenho certeza que se eles gastaram esse dinheiro porque vai valer a pena porque tenho certeza o Brasil vai ganhar.

G.M.S.M.

Anexo B - Texto 4

Neste texto, observamos que a autora se utilizou de várias vozes para compor seu texto; por exemplo, os trechos em destaque são citações do texto de apoio. Bakthin (2003, p. 297) justifica essa estratégia ao afirmar que " $E$ impossível alguém definir sua posição sem correlacioná-la com outras posições. "Sendo assim, ela se identifica com aqueles que apoiam a Copa do Mundo e refuta as manifestações, criticando os atos de vandalismo. Argumenta ao mostrar a consequência dessas atitudes, porém, deixa alguns enunciados incompletos, por exemplo, quando a estudante diz que o Brasil vai ganhar. (no quarto e no quinto parágrafo), não fica claro se o país vai ganhar a competição esportiva ou se vai ter benefícios econômico, mostrando mais uma vez o estilo conciso que já foi analisado nas produções anteriores. Faz uma tentativa de citar o texto de apoio, inadequadamente, "concordo com o Brasil". No texto citado, trata-se de uma fala do ex-presidente Luiz Inácio Lula da Silva. Embora ela não tenha indicado corretamente o enunciador, percebemos que é um reflexo das atividades nas quais foram analisadas citações para compor argumentos de autoridade.

A aluna, igualmente, não emprega os recursos linguístico-discursivos trabalhados em classe para organizar seu texto. $O$ uso de expressões coloquiais como "eu acho", "bacana", "legal" demonstra que não compreendeu o contexto de produção adequadamente, pois, em se tratando de texto a ser publicado, supostamente, no jornal da escola, deveria fazer outras escolhas lexicais. 
Como o texto foi produzido bem próximo ao início do evento, percebemos que, assim como aconteceu em todo país, houve uma atitude de resignação diante da situação, como vemos no trecho "já é tarde já gastaram o dinheiro não tem como voltar mais atrais". Além disso, sua opinião se concentra na realização do evento e não se reporta ao tema proposto. É provável que isso tenha acontecido devido aos debates, às pesquisas nos jornais e às participações no ambiente virtual.

\section{O que será do Brasil após a copa}

A copa do mundo traz muitos benefícios para nós brasileiros, pois será realizada em nosso país, pessoas de fora terão a chance de conhecer o Brasil, e seus lugares.

O Brasil investiu muito nessa copa então que o dinheiro que foi gasto que tenha algum fundamento, que venha a sair conforme o planejado uma copa boa com segurança e alegria que seja uma comemoração ótima.

Também trará muita preocupação com os gastos que foram usados para a realização esse dinheiro poderia ser usado em escolas, posto de saúde e hospitais e para as comunidades melhorar o acesso para as pessoas, tanto dinheiro jogado fora.

Brasil quer se mostrar para outros países e quando a copa acabar as coisas na loja supermercado irão subir para repor o dinheiro que foi gasto, agora as pessoas estão em greve lutando pelo seu direito na sociedade mas deveria ser quando estavam decidindo porque já está feito não adianta reclamar mais agora é esperar para ver.

P.H.S.B.F.

\section{Anexo B - Texto 5}

Este estudante assume uma posição favorável à Copa do Mundo, deixando claro seu ponto de vista sobre a inutilidade das críticas nesse momento. Articula argumentos ( "que o dinheiro que foi gasto tenha algum fundamento) e contraargumentos ("esse dinheiro poderia ser usado em escolas...") e retoma a tese de que "já está feito, não adianta reclamar". Ele demonstra ter feito um projeto de texto, embora ainda tenha problemas na sua organização, principalmente, no que tange ao uso de sinais de pontuação. Mas vale lembrar que todas as produções aqui analisadas são as produções originais, sem terem sido feitas quaisquer revisões.

O autor faz uso de elementos coesivos o termo a copa (no primeiro parágrafo) é retomado no segundo parágrafo nessa copa. O terceiro parágrafo inicia-se com "Também", operador argumentativo que acrescenta argumentos. Neste caso, retoma o referente, entretanto, introduz uma ideia contrária ao que foi exposto no parágrafo anterior. Percebemos uma tentativa de aproximação com o gênero em estudo, mas 
ainda faltam recursos que articulem seus enunciados para compor um texto persuasivo.

As análises dessa etapa forneceram-nos subsídios para refletir sobre os aspectos discursivos dos textos argumentativos. Bakthin (2003), aponta que há pessoas que, mesmo dominando a língua perfeitamente, quando expostas a determinados gêneros sentem dificuldade em concretizá-los por se tratar de esferas diferentes de sua vivência. Nossos alunos também têm dificuldades em se comunicar por meio do gênero jornalístico artigo de opinião, pois trata-se de um contexto ainda desconhecido para eles. Entretanto, como afirma Bakthin (2003, p. 285)

\footnotetext{
"Quanto melhor dominamos os gêneros tanto mais livremente os empregamos, tanto mais pleno e nitidamente descobrimos neles a nossa individualidade (onde isso é possível e necessário), refletimos de modo mais flexível e sutil a situação singular da comunicação; em suma, realizamos de modo mais acabado o nosso livre projeto de discurso"
}

Por isso, entendemos que o contato com o gênero, a experimentação de construção de textos de vários temas, a alimentação temática com leitura em gêneros variados auxilia na melhoria da argumentação. Se, como para Bakthin, cada enunciado corresponde a uma resposta a outros enunciados, é necessário que esses enunciados sejam apresentados para os alunos. Os estudantes relataram ser a primeira vez que trabalhavam com jornais em atividades escolares. Talvez seja essa ausência de familiaridade com gêneros secundários, conforme classificação de Bakthin (2003), a justificativa para o estilo e as construções típicas de gêneros primários nas suas produções (coloquialismo, frases concisas, enunciados incompletos, clichês etc.).

Retomando Geraldi (1991), quando o aluno tem o que dizer, o texto flui e se reveste de uma autoria, como vimos nos exemplos anteriores. Além dos textos analisados aqui, a maioria dos alunos desenvolveu um texto aceitável quanto ao assunto, enunciando sua opinião. Além disso, as atividades de pesquisa fomentaram o debate, trazendo mais informatividade ao texto, mas também demonstraram que o assunto teve prevalência sobre o tema. Aparentemente, o que importava era emitir uma opinião sobre o assunto e trazer para o texto algum conhecimento adquirido durante as atividades. 
Ainda que nem todas as marcas constitutivas do gênero artigo de opinião estejam adequadamente empregadas, há um progresso em relação à primeira produção textual analisada. A sequência injuntiva deixou de ser empregada, os tempos verbais empregados, na sua maioria, estão adequados ao gênero, ou seja, utilizam-se do tempo presente, do futuro do presente do indicativo e, algumas vezes, do futuro do pretérito do indicativo.

\subsection{DESCRIÇÃO E ANÁLISE DA AAP- 2ํ SEMESTRE: PRODUÇAO FINAL da SD}

Novamente o contexto de aplicação prejudicou o desenvolvimento das atividades de produção. A orientação dada aos professores é que se faça uma pesquisa com os alunos antes de se iniciar a escrita dos textos, mas a dinâmica da escola não permite que sejam utilizadas mais de duas aulas para a aplicação da avaliação.

No ensino fundamental, o pouco contato com textos jornalísticos e a falta de debates sobre temas da atualidade prejudicam sobremaneira a produção sobre temas pouco conhecidos.

A seguir, reproduziremos a Proposta de Avalição da Aprendizagem em Processo. Produção Textual- 9ํano do Ensino Fundamental- 2º semestre de 2014: 
AVALIAÇÃO DA APRENDIZAGEM EM PROCESSO / LÍNGUA PORTUGUESA

\title{
Produção Textual
}

\author{
$9^{\circ}$ ano do Ensino Fundamental \\ Turma \\ 2o semestre de 2014 \\ Data \\ Escola \\ Aluno
}

Caro aluno, a partir da leitura dos textos motivadores e, com base nos conhecimentos construídos ao longo de sua formação, redija um artigo de opinião em norma padrão da língua portuguesa, para ser publicado no jornal do bairro ou de sua região, sobre o tema: Rolezinho: direito dos jovens?

\section{TEXTO I}

\section{CULTURA DO ROLÊ}

OS GOSTOS MUSICAIS, AMODA EA LINGUAGEM DOS ADOLESCENTES DO MOVIMENTO

OS ÍDOLOS
DALESTE Assassinado em julho do ano passado durante
um show em Campinas, O MC é um dos maiores idolos
da galera. O videoclipe do hit São Paulo já soma mais
de 7 milhões de visualizaçōes no YouTube.
DIMENOR DR Daniel Almeida, o Dimenor DR,
é conhecido por seu talento para mesclar rimas
tipicas do rap e melodias de funk, sempre abordando
luxo e consumo como tema.
GuImÊ Antes da fama, trabalhava em uma quitanda
e hoje se destaca como uma das estrelas do setor,
chegando a faturar 300000 por mếs.

Figura 11- Proposta de produção textual - AAP- $2^{\circ}$ Semestre. P.1 


\section{AS GÍRIAS}

Bater um rádio: telefonar

Bonde: grupo que se reúne

Dimenor: menino mais novo

Colar: confirmar presença

Familia: grupo de amigos do mesmo bairro

Fita: situaçāo

Fluxo: baile de rua, mas pode ser também

uma coisa bacana

Marolar: ficar tranquilo

Mó Cota: durante muito tempo

Novinha: menina mais nova

Shopp: shopping

Zika: muito bom

Disponível em: <http://vejasp.abril.com.br/materia/rolezinho-no-shopping?gclid=CIT7jtTe3bwCFS1p7 Aodb2EAYg > Acesso em: 20 de fevereiro de 2014. (adaptado)

\section{TEXTO II}

\section{Chopis Centis}

Dinho / Júlio Rasec

Eu di um beijo nela

E chamei pra passear

A gente fomos no shopping

Pra mó de a gente lanchar

Comi uns bichos estranhos

Com um tal de gergelim

Até que tava gostoso

Mas eu prefiro aipim

[...]

Esse tal Chopis Centis

É muicho legalzinho

Pra levar as namoradas

E dar uns rolêzinhos

Quando eu estou no trabalho

Não vejo a hora de descer dos andaime

Pra pegar um cinema do Schwarzenegger

Tombém o Van Daime

$[\ldots]$

Disponível em:<http://letras.mus.br/mamonas-assassinas/24144/>. Acesso em: 30 de janeiro de 2014 (adaptado)

2 Avaliação da Aprendizagem em Processo • Produção Textual - $9^{\circ}$ ano do Ensino Fundamental

Figura 12- Proposta de produção textual - AAP- $2^{\circ}$ Semestre. p.2 
TEXTO III

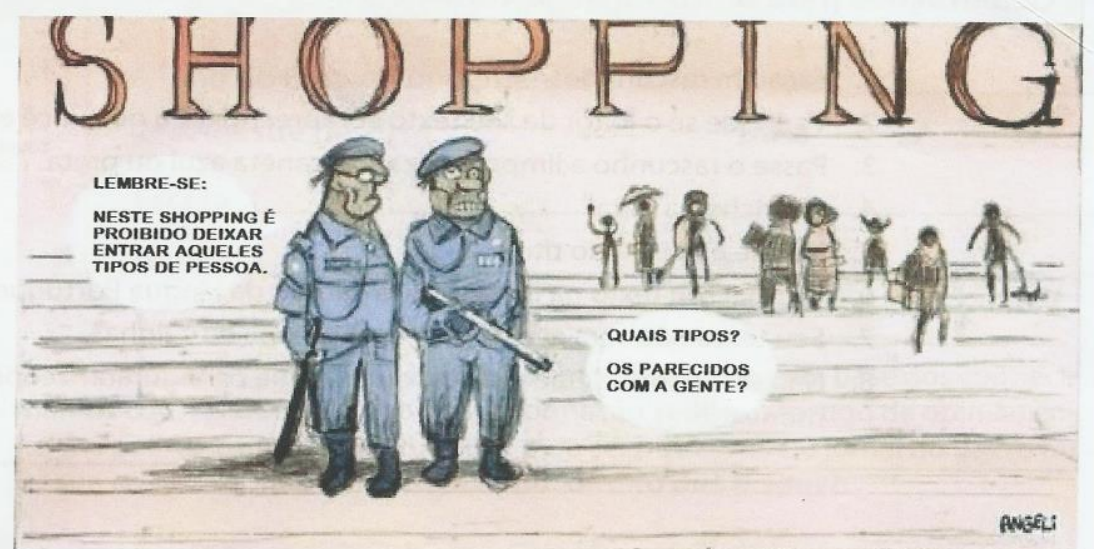

Disponível em:<http://www.revistacamocim.com/2014_01_15_archive.html>. Acesso em: 30 de janeiro de 2014.

\section{Agora é sua vez!}

Você leu três textos. Todos tratam de uma mesma temática: o 'rolezinho' em shoppings. O texto I traz algumas informações sobre a cultura do "rolê". O texto Il é a letra de uma música da década de 1990 e, embora não trate especifica'mente do tema, já usa o termo 'rolezinho' em sua composição. O texto III, por sua vez, é uma charge na qual dois policiais reportam-se à restrição de acesso de um determinado grupo de pessoas a um shopping.

Com base na leitura dos textos propostos, nos conhecimentos construídos ao longo de sua formação e com o auxílio do professor, redija um artigo de opinião sobre o tema: Rolezinho: direito dos jovens? para ser publicado no jornal de sua região.

Lembre-se de selecionar, organizar e relacionar, de forma coerente e coesa, argumentos e fatos para defender seu ponto de vista sobre o tema, ou seja, você deve se posicionar a favor ou contra o assunto em foco, deixando claro o que você pensa a respeito.

Figura 13- Proposta de produção textual - AAP- 2o Semestre. P.1

Após a leitura da proposta, houve uma forte resistência por parte dos alunos para escreverem o texto. Mesmo debatendo com eles sobre os textos de apoio, tecendo comentários sobre reportagens veiculadas pela televisão, falando sobre o movimento nas grandes cidades, eles se sentiram inseguros em escrever, pois desconheciam a razão de se debater algo tão distante. Como não havia um texto 
concreto para se apoiarem, não sabiam construir seu enunciado. A citação dos nomes de cantores pressupunha que o leitor os conhecesse e que também soubesse do contexto de produção de cada estilo. $O$ discurso da charge deixava implícito que os seguranças também provinham da classe dos manifestantes, mas tal aspecto não foi compreendido claramente pelos alunos. A música tampouco os ajudou a pensar na discriminação de grupos sociais, pois no contexto da música, o "rolezinho" era algo positivo, ainda não estava revestido do discurso que poderia desencadear a questão polêmica sugerida na proposta.

Como já havia transcorrido grande parte da aula e os alunos se negavam a iniciar a produção textual, elaboramos coletivamente algumas perguntas para motivar a escrita, por exemplo; o que é "rolezinho"? Quem participa? Por quê? Como essas pessoas são vistas? Você concorda como elas são tratadas? etc. Essa estratégia que, no momento, nos pareceu a mais adequada para a concretização da atividade, conforme pesquisas posteriores Costa (2000), impregnou a produção de um caráter escolar, retirando-se a oportunidade de outras escolhas linguísticodiscursivas, pertinentes ao gênero artigo de opinião. Como as perguntas foram registradas no quadro, alguns alunos, mesmo sendo esclarecidos que deveriam construir um texto, limitaram-se a responder sucintamente às perguntas.

Participaram desta avaliação 20 alunos, dos quais 13 escreveram uma sequência argumentativa, 7 escreveram sequência descritiva, com pouca ou nenhuma argumentação. Não tivemos textos com cópia na íntegra, como ocorreu nas avaliações anteriores, pois, infelizmente, aqueles alunos ou abandonaram a escola ou se ausentaram nos dias de aplicação dessa avaliação.

Decidimos analisar as produções dos mesmos estudantes da avaliação anterior para termos um parâmetro de comparação.

\section{O rolezinho}

Rolezinho é um encontro entre amigos, que saiem para se divertir, hoje em dia isso é comum, entre jovens. Geralmente acontece em shopping mas em cidades pequenas em praças, calçadão e posto.

Quem participa? Grupos de amigos, na minha cidade por exemplo, tem vários essas pessoas geralmente são quem gosta de funk. A sociedade pensa que só vândalos fazem isso, mas não é bem assim.

Alguns saem pra se divertir, outros vão na maldade de roubar, quebrar coisas, isso não é um direito. Vai quem quer e também ninguém é obrigado a gostar, mas sim respeitar. 
Isso é um gosto e cada um tem o seu, hoje em dia isso é quase um estilo, é mais do que normal como qualquer outra coisa, porém um pouco diferente.

J.R.B.S.

Anexo C - Texto 1

Notamos que a estudante parece seguir as orientações dadas na etapa do planejamento. Por exemplo, no primeiro parágrafo há uma definição do termo "rolezinho", já no segundo parágrafo, faz uma alusão a quem participa e apresenta uma opinião, afirmando que a sociedade considera todos como vândalos, mas que em seu ponto de vista, não são todos que poderiam ser assim categorizados.

A noção do gênero vai se solidificando, pois ela usa alguns argumentos para defender a atitude de quem faz essas manifestações, como por exemplo: "outros vão na maldade de roubar, quebrar coisas, isso não é direito...ninguém é obrigado a gostar, mas sim respeitar"

Apesar de não dominar bem o gênero, essa aluna demonstrou em suas produções, uma melhora na qualidade da escrita. Na primeira escrita da carta argumentativa elaborou um parágrafo, na reescrita expandiu os períodos e acrescentou argumento; na avaliação bimestral, posicionou-se em relação ao tema e buscou argumentos para defender sua tese. Mesmo que ainda apresente alguns problemas de ordem gramatical como, pontuação e coesão, nessa última produção, o texto está organizado em parágrafos com tópicos definidos.

\section{Você sabe o que é rolezinho?}

Antigamente rolezinho era somente dar uma volta, passear, ir em alguns lugares com os amigos, era simplesmente se divertir indo a lugares com seus amigos, mas isto acabou mudando com o tempo. Há várias opiniões sobre esse assunto, muitos chegam a ser discriminados só por usar roupas diferentes e usarem gírias informais, e acabam sendo julgadas mal pela sociedade de hoje em dia, Atualmente rolezinho significa se juntar a várias pessoas e ir a algum lugar para roubar, saquear, badernar, resumindo fazer vandalismos. Infelizmente isto acaba se tornando uma coisa horrível que afeta toda a sociedade, muitas famílias quase nem saem de casa por causa destes vândalos que ficam fazendo estes rolezinhos, antes rolezinhos era somente dar uma volta, mas agora tudo mudou, e não mudou para melhor, o rolezinho de atualmente chega a ser Putrefato, esta é minha opinião sobre o rolezinho, e isto só irá piorar com o passar do tempo.

L.H.A.C

Anexo C - Texto 2

Esse estudante demonstra ter compreendido a proposta de produção quanto ao tema, mas tem dificuldade em estabelecer uma questão polêmica. Usa a definição para defender seu ponto de vista, afirmando que o movimento do 
"rolezinho" afeta toda a sociedade. Indica uma consequência: "muitas famílias quase nem saem de casa por causa destes vândalos...". Todavia, como na maioria dos textos analisados, o aspecto persuasivo se mostra insuficiente. Não há uma tentativa de convencer o destinatário a comungar com o enunciador. $\mathrm{O}$ que fica reforçado pelo enunciado: "esta é minha opinião sobre o rolezinho". Parece-nos que não se importa com o que o seu leitor pensa; dá o direito a ele de pensar o que quiser. Típico de enunciadores que, segundo Perelman \& Olbrechts-Tyteca(1996), abrem mão de persuadir o interlocutor para não negociarem suas convicções.

$\mathrm{Na}$ produção anterior deste aluno, houve uma melhor organização dos parágrafos, mas manteve a argumentação, analisando as consequências das atitudes dos manifestantes, apontando ressalvas quanto à má interpretação da sociedade que generaliza concepções sobre seus estilos linguístico e visual.

Rolezinho a podridão e modo de se epressar xulo e baixo da sociedade tola, procuram modos que chocam e pertubam e importunam as pessoas que estão simplesmente vivendo suas vidas.

O rolezinho somente serve para fazer graça e vagabundagem e ainda além de ocorrer vandalismo e assaltos, muitos dos mais podres que já lá exitem ainda fazem musicas e dão depoimentos e criam letras que dizem "a dificuldade e falta de opção" sendo que em vez de estudarem ficam desfilando importunando as pessoas "com bom senso".

O rolezinho é composto por jovens sem motivos e com mentes putrefatas e afetadas pelo funk, o funk denigre os de pouca resistência, tolos, ignorantes, que encontram e enfiam todo o suado dinheiro em igrejas evangélicas pois são ignorantes e o resto em bailes procurando tolice e libertinagem pois isso que "ta na fita".

Obviamente é direito como qualquer movimento social é sem cultura, porém uma coisa ser cultura não quer dizer que seja apropriado e bom e ser direito. Temos de lembrar do bom senso de que muita gente não quer ver em ouvir seu podre e insensato "Rolezinho"

No rolezinho acontecem coisas que além de perturbar existem ladrões e vândalos como já citei.

A sociedade normal e pensadora vê que o erro já está ali, porém não se mobilizam vão para o shopping e aguentam todas as vezes.

K.A.A.

O que poderíamos fazer, colocar uma nova lei "o bom senso"

Anexo $\mathrm{C}-$ Texto 3

A questão do estilo fica clara na produção deste aluno, não só as escolhas lexicais marcam o seu discurso, mas também a pontuação, a atitude agressiva e irreverente diante da opinião alheia. Talvez essa irreverência tenha sido estimulada 
pelos textos da proposta, com alusão ao universo do funk, o discurso dos manifestantes nas redes sociais e pelo contexto social veiculado pelas mídias televisivas. Essa característica é atribuída por Perelman \& Olbrechts-Tyteca(1996) aos oradores apaixonados, que consideram os argumentos que o convenceram tão evidentes que ignoram um outro modo de pensar, ou seja, as opiniões contrárias. Nas produções anteriores, fizemos a revisão da pontuação, mostrando ao aluno que, às vezes, a falta de pontuação pode causar ambiguidade e orientei para que ele lesse sua produção antes de entregar o texto final. Mesmo assim encontramos ainda problemas pontuais de construção, como por exemplo "ficam desfilando importunando as pessoas 'com bom senso'”. Só com uma leitura mais atenta podemos apreender que o termo "com bom senso" se refere a um grupo de pessoas, funcionando como adjunto adnominal.

Considerando o conceito de enunciado pleno de Bakhtin (2003), no qual o enunciado não se faz somente com a delimitação de frases e oração, podemos afirmar que há argumentação suficiente para persuadir o interlocutor que apoia o "rolezinho".

Quanto às orientações dadas em sala, percebemos uma tentativa de organizar os parágrafos em tópicos, encerrando o texto com uma proposta de solução: "O que poderíamos fazer, colocar uma nova lei 'o bom senso'”. Ele também assume um papel social, buscando a adesão de quem não gosta de funk e se sente incomodado com esse estilo musical.

Ressalvadas as incorreções gramaticais, esse texto se aproxima de artigos de opinião, publicados normalmente em jornais.

Rolé de hoje em dia

Hoje em dia o rolezinho é um "bonde" de pessoas adolesentes que saem para se divertir ou dar um rolé, eles vão muito nas praças, no shopping, no calçadão, barzinho, fazem esse grupo, esse "bonde" de adolescentes para por o papo em dia, beber um pouco dar uma volta, porque aliás todos são livre para sair cada um tem seu direito.

Existe o rolezinho o "bonde" dos adolescentes para eles sair e se divetir. Não quer dizer que eles são livres para fazer o que quer. Sim, claro, são livres, mas existem leis, porque tem uns bondes de adolescentes que gosta de montar um grupo para ir ao shopping para roubar, bater nas pessoas, estragar algo. E isso não está certo cada um tem que ter seu limite e respeitar a todos.

No rolezinho dos adolescentes é um grupo com mais de 5 pessoas ou mais não dá para saber isso pode ser pouco ou bastante depende de cada grupo, isso é 
apenas uma fase da vida isso tudo passa é direito de cada um ser livre mais sabendo ser sem aprontar porque pode prejudicar a si mesmo.

Tem vários tipos de pessoas num rolezinho, os mais Top's, os emos, os rockeiros, os skatistas, funkeiros... cada um tentando se divertir.

O que a sociedade pensa eu não sei por que cada um tem sua opinião, a minha opinião é deixar eles ser feliz mais sem prejudicar ninguém, podia mudar algumas coisas poucas coisas, por que acho que iria melhorar um pouco mais ia servir pra quem não respeita.

G.M.S. M.

Anexo C - Texto 4

Assim como nas demais produções, o uso da norma padrão da língua portuguesa, requerida na proposta, não está ainda inserida nas produções dos alunos, o que motivou as intervenções após as avaliações serem corrigidas pela professora. Vemos, aqui, a tentativa de organizar os textos em parágrafos; contudo, nem todos os períodos são marcados por pontuação. Mesmo assim, esses desvios não prejudicam a coerência. Compreendemos a proposta que sugere apenas controlar o movimento dos "rolezinhos", argumento favorável à tese que "todos são livres para sair cada um tem seu estilo". Faz uma ressalva a quem usa o movimento para destruir "Não quer dizer que eles são livres para fazer o que quer, mas existem leis".

Há problemas sérios de coesão, como por exemplo, no primeiro parágrafo em que define o "rolezinho" como " 'bonde' de pessoas adolescentes que saem para se divertir ou "dar um rolé". Repete quase a mesma ideia no segundo parágrafo: "Existe o rolezinho o "bonde" dos adolescentes para eles sair e se divertir". No terceiro parágrafo, a estudante começa com a expressão: "No rolezinho dos adolescentes...", criando a expectativa de uma circunstância, mas volta a definir o movimento social, a enfatizar o número de participantes, tecendo uma análise a respeito dessa quantidade. Sem prévio aviso muda a direção do texto "isso é apenas uma fase da vida isso tudo passa é direito de cada um ser livre mais sabendo ser sem aprontar porque pode prejudicar a si mesmo" Dentro de um enunciado global, podemos entender que isso retoma o movimento dos "rolezinhos", mas ao analisarmos o texto, parece-nos que a estudante fez uma lista de informações relativas ao tema, mas não houve tempo de organizá-las no desenvolvimento do texto. Neste caso, pode ter faltado orientação quanto às estratégias de revisão textual. 
Embora ainda faltam serem trabalhados aspetos coesivos, percebemos que essa estudante demonstrou ter avançado quanto à formulação dos aspectos argumentativos e composicionais do gênero artigo de opinião.

O que é rolezinho

Rolezinho é uma forma que os jovens usam para definir: dar uma volta, ir na cidade, sair com os amigos, em geral se divertir.

A maioria que sai de rolezinho são jovens e adolescentes, por que para eles está na moda o termo rolezinho, por que é atual na linguagem dos jovens.

O rolezinho é um direito por que nós, seres humanos, somos livres para sair, passear, se divertir, mas temos que ter respeito nas leis do local em que se encontra.

$\mathrm{Na}$ minha cidade se encontram algumas pessoas que usam essa palavra, tem lugares em que se encontra essas pessoas geralmente essas pessoas se encontram em baladas, lugares onde muitas pessoas frequentam, lugares mais populares.

Essa palavra existe por que alguns MC utilizam essa palavra em suas músicas, por isso essa palavra é popular na boca das pessoas que curtem esses tipos de músicas como o funk.

P.H.S.B.F.

Anexo $\mathrm{C}-$ Texto 5

Observamos nessa produção, que o estudante assume uma atitude responsiva ao debate da sala, além de demonstrar que também assimilou o enunciado dos textos legais que foram lidos por ocasião da produção da carta. Ele diz que "o rolezinho é um direito por que nós, seres humanos, somos livres" e acrescenta "mas temos que ter respeito nas leis do local em que se encontra".

Percebemos, claramente, que ele defende um ponto de vista favorável ao movimento social. Afirma que os jovens usam esse termo porque está na moda, mas pode haver outros significados conhecidos, como "dar uma volta, ir na cidade, sair com os amigos, em geral se divertir". Ou seja, considera o movimento natural entre os jovens, concordando com ele desde que não desrespeitem os direitos de outras pessoas. Embora tenha empregado poucos argumentos e tenha faltado uma conclusão (nova tese) explícita, o texto se aproxima das orientações dadas em sala.

Há problemas de coesão, principalmente nos últimos parágrafos, repetição da palavra "pessoas" (quarto parágrafo) e "palavra" (quinto parágrafo). Relendo as produções dos outros alunos, percebemos que esse fato é uma constante nos textos de alunos que não fazem um projeto e tentam acrescentar mais ideias para garantir o número de linhas exigido para serem avaliados. Sabemos que isso prejudica a movimentação argumentativa e também a força persuasiva, por isso esse texto não 
parece convincente ao leitor. Ainda que tenha selecionado informações pertinentes para construir seu enunciado, utilize da norma padrão, não faz uso de todos os recursos do gênero artigo de opinião, estudados durante as aulas. Mas, se compararmos às suas produções anteriores, podemos observar que houve uma busca em fazer adequações linguísticas ao gênero requerido.

Após a conclusão das análises, podemos tecer algumas reflexões sobre o desenvolvimento do nosso trabalho. Essas reflexões não têm a pretensão de esgotar todos os aspectos, nem serão apresentadas segundo uma ordem hierárquica.

Em relação às atividades apresentadas, em ambos materiais didáticos adotados pela escola, consideramos que elas ainda são insuficientes para que o aluno escreva um artigo de opinião.

As estratégias para estudar os operadores argumentativos talvez não tenham sido trabalhadas adequadamente, tanto aquelas do livro didático quanto as do apostilado do Estado De São Paulo (caderno do aluno), ou seja, os alunos não incorporaram a sua aprendizagem à produção de texto. As atividades propostas no apostilado propunham ao aluno pesquisar o valor semântico de conjunções coordenativas e subordinativas e escrevessem parágrafos argumentativos com o auxílio dessas palavras. Poderíamos ter explorado mais essas atividades, identificando o uso em situações reais, como, por exemplo, nos textos jornalísticos lidos em sala.

Durante o desenvolvimento da SD demos mais ênfase em trabalhar ao trabalho com informações, em detrimento do estudo das características do gênero. Talvez isso tenha ocorrido por sermos motivados pela avaliação inicial e pela produção das cartas, com textos muito concisos.

Temos que considerar o fato de que quase todas as produções foram realizadas em situação de avaliação. Isso determina o contexto de produção e recepção dos textos, influenciando assim nos resultados.

Ressalvando as dificuldades apresentadas quanto ao uso da variedade da língua, temos produções textuais que "ensaiam" um artigo de opinião. Percebemos o aluno como sujeito de seu próprio texto, posicionando-se como ser social, utilizandose de enunciados apreendidos na interação com os gêneros orais e escritos, 
veiculados em sala. Assim, podemos afirmar que há um progresso quanto à produção escrita de modo geral, mas também devemos nos preocupar em redirecionar as ações pedagógicas para propiciar o domínio do gênero.

Talvez uma outra sequência didática que priorize os articuladores textuais ao mesmo tempo que oriente para uma pontuação adequada à argumentação seja necessária para que esses estudantes avancem um pouco mais na produção escrita. A introdução de estratégias de reescrita também será fundamental para melhorar a qualidade do texto final. 


\section{CONSIDERAÇÕES FINAIS}

Quando o professor assume uma sala de aula no início do ano, tem diante de si um duplo desafio: cumprir com o currículo determinado pelo sistema ao qual está vinculado e, ao mesmo tempo, precisa adequar-se às condições materiais e de aprendizagem da turma.

O currículo do Estado de São Paulo, ao qual está submetida a escola desta pesquisa, prevê o ensino de gêneros argumentativos no $9^{\circ}$ ano do ensino fundamental. Além disso, o sistema de ensino propõe, em suas avaliações externas, SARESP e AAP, a produção de um artigo de opinião. Tínhamos então um problema: como planejar atividades didáticas que favorecessem o ensino-aprendizagem do gênero argumentativo, artigo de opinião, em uma sala com sérios problemas de aprendizagem em relação à escrita?

Após a análise do material de apoio proposto pelo Governo do Estado de São Paulo, caderno do aluno e caderno do professor, do livro didático adotado pela escola e a realização de pesquisas teóricas, a escolha por organizar as atividades em sequências didáticas, conforme orientações do grupo de Genebra, mostrou-se adequada aos nossos propósitos, pois favoreceria o uso das atividades pertinentes ao gênero, oferecidas pelos materiais disponíveis.

Logo nas primeiras produções, percebemos as dificuldades dos alunos em se expressarem por escrito, pois os textos evidenciavam marcas de oralidade, concisão típica da fala, dificuldades para construir argumentos, dificuldades em delimitar as frases etc. Essa percepção motivou a elaboração de duas sequências didáticas: uma para a produção de carta argumentativa e outra para a produção de artigo de opinião, ambas com o objetivo de trazer a argumentação escrita para a realidade dos estudantes.

Como foi visto no capítulo 4, a produção de cartas argumentativas, como primeira etapa para introduzir a argumentação, trouxe alguns avanços para a produção do texto de forma geral. Na reescrita, houve melhora significativa do volume informativo dos textos, além de acréscimo de alguns argumentos.

Sabendo que a turma possuía pouca experiência com a leitura, consequentemente sendo dotada de um repertório linguístico limitado, os textos 
selecionados para as atividades abordavam assuntos do cotidiano, pretendendo assim, aproximar os alunos do universo da escrita. Mas, talvez influenciados pelas temáticas desses textos e pelo espírito coletivo de protestos que repercutiam pelo país no ano de 2014, ano do desenvolvimento da pesquisa, os textos produzidos pelos alunos não se constituíram como artigo de opinião típicos. Entretanto, são textos coerentes, com uma significativa melhora na informatividade, relativa organização em parágrafos, apresentando um processo argumentativo em construção.

Outro provável fator de influência sobre o resultado foi a extensão da SD, pois não foi possível manter o foco na produção do gênero após o desenvolvimento de atividades ora prolongadas, como as do livro didático, ora diversificadas, como as do caderno de apoio. Além disso, as atividades planejadas precisaram ser alternadas com outras atividades previstas para o período, mas que não tinham como objetivo principal a produção de texto. Infelizmente, essa observação só nos foi possível com o distanciamento da ação e após leituras posteriores ao momento de planejamento e execução da SD.

Considerando, ainda, as atividades de preparação, reconhecemos algumas falhas quanto ao tratamento dado às atividades relativas ao ensino-aprendizagem do uso dos operadores argumentativos. Mesmo sabendo da relevância desse recurso para a construção da argumentação, as atividades propostas pelos materiais não foram exploradas adequadamente e a pouca intervenção nessas situações pode ter resultado nas limitadas ocorrências desses recursos nos textos produzidos pelos alunos, nas avaliações finais.

Nosso objetivo foi alcançado, pois, apesar das limitações quanto ao uso dos recursos linguísticos da escrita, os estudantes produziram textos nos quais puderam exercer uma argumentação cidadã. Partiram de uma produção inicial, na qual apenas construíram uma sequência descritiva ou injuntiva, opinando com argumentos apoiados nos textos da proposta para a produção de textos mais próximos de artigo de opinião, utilizando-se de sequências dissertativas, tempos verbais adequados e, frequentemente, posicionando-se socialmente quanto ao tema proposto.

Uma vez que o professor de língua portuguesa é responsável, em primeira instância, por ensinar o aluno a ler e escrever com autonomia, toda ação didáticopedagógica desses profissionais deve primar por uma reflexão sobre o seu objeto de 
trabalho, ou seja, a língua. Por isso, essa pesquisa veio contribuir com a prática, possibilitando um novo olhar sobre as teorias linguísticas e sua relação com o processo de ensino-aprendizagem de língua portuguesa.

Os princípios da linguística aplicada, da análise do discurso e demais teorias que consideram a língua como um evento social, em especial os conceitos postulados por Bakhtin (2003), puderam ser observados e comprovados neste trabalho, pois os enunciados produzidos pelos alunos revelaram a dialogicidade com outros discursos, com o predomínio dos textos midiáticos, revelando um sujeito socio-histórico condizente com a faixa etária dos estudantes. Numa perspectiva bakthiniana, os textos dos alunos são respostas ao contexto político pelo qual o país passava no momento da produção textual, materializado nos mais diversos enunciados (postagens em redes sociais, jornais televisivos, conversas cotidianas na família, anúncios publicitários etc.).

Quanto ao estudo do gênero artigo de opinião e sua adequação ao contexto de sala de aula, podemos ressaltar alguns aspectos relevantes. Primeiro, as concepções de gêneros textuais/discursivos apontadas pelos PCNs e retomadas pelo Currículo do Estado de São Paulo não estão sendo contempladas adequadamente nas propostas de atividades oferecidas pelos materiais didáticos que circulam na escola pública. Em primeiro lugar, ora as orientações focam na tipologia textual, ora oferecem um único texto para análise do gênero. Em segundo lugar, quando se propõe o estudo de um gênero discursivo, é preciso garantir que a sua função social seja a mais próxima da realidade. Entretanto, ao se propor a produção escrita de um gênero em avaliações externas, a sua finalidade passa a ser a nota e não uma resposta a um questionamento real. Por último, é preciso considerar o resultado do trabalho como uma aproximação desse gênero, pois, como diagnosticado no início desta pesquisa, os alunos pertencem a um contexto socioeconômico-cultural desfavorável, com pouca experiência de leitura e habituados a fazerem cópias em quase todas as disciplinas.

Não sendo nossos alunos especialistas nos assuntos propostos, evidentemente recorreram aos meios acessíveis a eles, fazendo uso de construções cristalizadas pelo senso comum. Isso é considerado pela Nova Retórica como uma má escolha e não como uma falha de argumentação. Apesar disso, mesmo reconhecendo como verdadeiros os postulados dos autores, admitindo também o valor argumentativo da linguagem, a ausência da neutralidade em todo e qualquer 
enunciado, o processo de ensino-aprendizagem deve contemplar ações que potencializem o domínio da leitura e escrita, pois só assim o estudante terá acesso a todas as oportunidades oferecidas pelo mundo letrado.

Durante o processo de revisão bibliográfica, no início da pesquisa, vimos em Schiavoni (2009), Grillo (1995) e Antunes (2003) o quanto era importante as atividades de retextualização. Entretanto, ocorreram situações em que alguns alunos abandonaram a reescrita, outros reescreveram literalmente o texto $e$, ainda, inutilizaram suas atividades; mesmo assim, deveríamos ter persistido no processo de reescrita, garantindo um melhor domínio da modalidade escrita da língua.

O problema de um currículo único para públicos tão diferentes é que o resultado pode ser menos expressivo do que o esperado. Por exemplo, após o diagnóstico da sala, se não tivéssemos a contingência de preparar os alunos para uma segunda avaliação, teríamos mais liberdade de trabalhar efetivamente nas necessidades de aprendizagem dos estudantes. Além disso, a falta de recursos e a pressão para usar os materiais fornecidos pelo sistema de ensino, muitas vezes, limitam o trabalho docente.

Não temos a pretensão de esgotar a análise da situação apresentada, neste trabalho, pois muitos são os fatores que contribuem para uma prática efetiva do ensino de língua materna. Nesse processo, não podemos perder de vista os avanços obtidos, pois são eles que ressignificam o fazer pedagógico. São muitos professores passando pelos mesmos problemas, muitos alunos como os nossos, dando um passo a cada dia na direção da conquista de uma cidadania plena.

Tendo em vista as dificuldades apresentadas pelos alunos, comparados aos resultados das análises, e também, considerando a complexidade do gênero, propomos algumas sugestões para o trabalho com o gênero "artigo de opinião"; vejamos:

a) Elaboração de sequências didáticas pontuais, ou seja, por exemplo, se o objetivo é trabalhar a questão polêmica, oferecer dois ou mais artigos de opinião para que os alunos percebam a ocorrência dessa característica por meio da comparação dos enunciados de autores diferentes. Caso o objetivo seja verificar o uso dos operadores argumentativos, selecionar textos bem escritos, nos quais se evidenciam o uso desses recursos, demonstrando a relação entre eles e a argumentação construída. 
b) Deve-se manter o cuidado de não repetir os equívocos de muitos materiais didáticos que procuram trazer trechos de textos como pretextos para analisar certas características de um gênero. Todas as atividades devem contar com textos integrais, com mais de um exemplar, trazendo as referências do contexto de produção e de circulação.

c) Ao final de cada sequência, propor um tema a ser pesquisado antes de apresentar uma proposta de produção. A pesquisa deve ser orientada para a seleção de informações que contribuam com o objetivo daquela sequência. Elaborar um roteiro de pesquisa é uma boa estratégia para turmas que apresentam muitas dificuldades de aprendizagem.

d) As atividades de análises de textos não devem ser exaustivas, sendo facultado a elas contemplar apenas alguns aspectos do gênero textual estudado. Os aspectos discursivos devem ter papel de destaque nas análises do gênero artigo de opinião, tendo em vista sua finalidade e considerando a heterogeneidade de seus aspectos composicionais, como afirma Rodrigues (2005).

e) As propostas de produção textual devem estar vinculadas às situações próximas das condições autênticas, ou seja, como não é possível enviar todos os textos para um jornal real, a produção de um jornal escolar possibilitará ao enunciador determinar seu interlocutor e auxiliar nas escolhas de estratégias persuasivas mais adequadas ao público.

f) Atividades de revisão e retextualização devem ser introduzidas e desenvolvidas como parte do processo de produção. É preciso que o aluno entenda $o$ aspecto interativo da língua, considerando o olhar do outro sobre o seu texto, aceitando o texto como um projeto inacabável, sem, com isso, desmerecê-lo.

Por mais duras que sejam as críticas ao nosso próprio trabalho, não as entendemos aqui como fracasso, mas, antes, como parte do processo de desenvolvimento, tanto da pesquisadora, como da professora. Pois como diz Guimarães Rosa "Mestre não é quem sempre ensina, mas quem de repente aprende". 


\section{REFERÊNCIAS BIBLIOGRÁFICAS}

ALVES, Francisco Filho. Gêneros jornalísticos: notícias e cartas de leitor no ensino fundamental. São Paulo: Cortez, 2011

ANTUNES, Irandé. Aula de português: encontro \& interação. 8aㅡ ed. São Paulo: Parábola Editorial, 2003.

ARISTÓTELES. Retórica. Tradução Manuel Alexandre Júnior. São Paulo: Martins Fontes, 2012.

BAKHTIN, Mikhail Mjkhailovitch. Os Gêneros do Discurso. In: Estética da Criação Verbal. Tradução Paulo Bezerra. 6 ed. São Paulo: Martins Fontes, 2003 [1979] p. 261-306.

- Questões de estilística no ensino da língua. Tradução, posfácio e notas de Sheila Grillo e Ekaterina Vólkova Américo. Apresentação Beth Brait.São Paulo: Editora 34, 2013

BAZERMAN, C. Gêneros textuais tipificação e Interação. Ângela Paiva Dionísio, Judith Chamblis Hoffnagel (orgs.). Revisão técnica Ana Regina Vieira et al. $4^{\underline{a}}$ ed. São Paulo: Cortez Editora, 2011.

BORTONI-RICARDO, Stella Maris; MACHADO, Veruska Ribeiro(orgs). Os Doze Trabalhos de Hércules: do oral para o escrito.São Paulo: Parábola,2013

BORTONI-RICARDO, Stella Maris; MACHADO, Veruska Ribeiro; CASTANHEIRA, Salete Flôres(orgs). Formação do professor como agente letrador. São Paulo: Contexto, 2010.

BRAIT, Beth. PCNs, Gêneros e Ensino de Língua: faces discursivas da textualidade. In: ROJO, Roxane (org.). A prática de linguagem em sala de aula. São Paulo: Mercado das Letras, 2000, p. 13-23.

BRÄKLING, Kátia Lomba. Trabalhando com artigo de opinião: Re-visitando o eu no exercício da (re)significação da palavra do outro. In: ROJO, Roxane (org.). A prática de linguagem em sala de aula. São Paulo: Mercado das Letras, 2000, p. 221-247. 
BRASIL. Constituição (1988). Emenda constitucional no 41, de 19 de dezembro de 2003. Modifica os arts. 37, 40, 42, 48, 96, 149 e 201 da Constituição Federal, revoga o inciso IX do $\S 3$ do art. 142 da Constituição Federal e dispositivos da Emenda Constitucional no 20, de 15 de dezembro de 1998, e dá outras providências. Disponível em <https://www.planalto.gov.br/ccivil_03/Constituicao/Emendas/Emc/emc41.htm>. Acesso em: 2 jun. 2006.

SEF. Parâmetros Curriculares Nacionais: Terceiro e Quarto Ciclos do Ensino Fundamental: Língua Portuguesa. Brasilia: MEC/SEF, 1998

. Censo Escolar da Educação Básica. Brasília: INEP, 2013. Disponível em http://portal.inep.gov.br/basica-censo-escolar-matricula acesso em 09/09/2014-11:13 http://saresp.fde.sp.gov.br/2013/\#

BRITO, Luiz André Neves. Discurso, leitura e produção textual: uma análise discursiva da escrita de pré-universitários. Disponível em: http://www.teses.usp.br/teses/disponiveis/8/8142/tde-08012013-161935/pt-br.php

CAGLIARI, Luiz Carlos. Alfabetização e linguística. São Paulo: Scipione, 2009.

CARNEIRO, Agostinho Dias. Redação em construção: a escritura do texto. São Paulo: Moderna, 1993.

CECÍLIO, Sandra Regina. O ensino de Língua Portuguesa e os gêneros discursivos: um estudo de análise linguística a partir dos gêneros carta de reclamação e texto de divulgação científica. 2009. Tese (Doutorado em Estudos da Linguagem) Universidade Estadual de Londrina, Londrina, 2009

Disponnível em:

http://www.dominiopublico.gov.br/pesquisa/DetalheObraForm.do?select action=\&co obra $=136607$. Acesso em 30/06/2014

COSTA, Cristina Fontes de Paula. O gênero resumo na universidade: Dialogismo e responsividade em resumos de alunos ingressantes.

Dissertação (mestrado) - Universidade Estadual de Campinas, Instituto de Estudos da Linguagem, 2013. Disponível em:

http://www.bibliotecadigital.unicamp.br/document/?code=000913188. Acesso em:14/03/2015

COSTA, Sérgio Roberto. A construção de "Títulos" em gêneros diversos: um processo discursivo polifônico e plurissêmico. In: ROJO, Roxane (org.). A prática de linguagem em sala de aula. São Paulo: Mercado das Letras, 2000, p. 67-90. 
DELMANTO, Dileta; CARVALHO, Laiz B. Jornadas. Port- Língua Portuguesa. São Paulo: Saraiva, 2012.

DIONISIO, Angela Paiva;MACHADO, Anna Rachel; BEZERRA, Maria Auxiliadora(org.). Gêneros textuais \& Ensino. Rio de Janeiro: Lucerna, 2005.

DOLZ, Joaquim; SCHNEUWLY, Bernard. Sequências didáticas para o oral e a escrita: Apresentação de um procedimento.In: SCHNEUWLY, Bernard ; DOLZ, Joaquim e colaboradores. Gêneros Orais e Escritos na Escola. Tradução e organização de Roxane Rojo e Glaís Sales Cordeiro. 3 ed. Campinas: Mercado de Letras, 2004

Folha de S. Paulo. Manual da Redação. 1992.Disponível em:

http://www1.folha.uol.com.br/folha/circulo/manual_texto_a1.htm

GERALDI, João Wanderely. Portos de passagem $-2^{\mathrm{a}}$ ed. São Paulo: Martins Fontes, 1991.

GOMES, Maria Lúcia de Castro. Metodologia do ensino de Língua Portuguesa. São Paulo: Saraiva, 2009

GRILLO, Sheila Vieira de Camargo. Escrita, Professores e alunos, análise de interação em educação. Disponível em:

http://www.bibliotecadigital.unicamp.br/document/?code=vtls000095797\&opt=4 .

Acesso em: 21/09/2013

PUC-RS. Guia de Produção Textual: texto argumentativo. Disponível em:

http://www.pucrs.br/gpt/argumentativo.php. Acesso em 10/02/2014

$\mathrm{KOCH}$, Ingedore Grunfeld Villaça. Introdução à linguística textual. 2ª̃ed. São Paulo: Editora WMF Martins Fontes, 2009.

Argumentação e linguagem. 13ª ed. São Paulo: Cortez, 2011

, ; ELIAS,

Paulo: Contexto, 2012. Ler e escrever: estratégias de produção textual. 2.ed. São ; TRAVAGLIA. A coerência textual. 18 ed. São Paulo: Contexto, 2014. 
KÖCHE, Vanilda Salton; BOFF, Odete Maria Benetti; MARINELLO, Adiane Fogali Marinello. Leitura e produção textual: gêneros textuais do argumentar e expor. 5ed. Petrópolis, RJ: Vozes, 2014

KLEIMAN, Ângela B. Preciso "Ensinar" o Letramento?: Não basta ensinar a escrever? .Campinas , UNICAMP/MEC, 2005

KRAMER, Sônia. Escrita, experiência e formação- múltiplas possibilidades de criação de escrita. In: Linguagens, espaços e tempos no ensinar e aprender/Encontro Nacional de Didática e Prática de Ensino (ENDIPE). Rio de Janeiro: DP\&A, 2000.

LEAL, T.F. Produção de textos na escola: a argumentação em textos escritos porcrianças. Tese de Doutorado. Recife: UFPE, Pós-graduação em Psicologia Cognitiva, 2003. Disponível em:

http://www.ufpe.br/sib/index.php?option=com content\&view=article\&id=197\%3Abdtd page\&catid=1\&ltemid=227 acesso em 30/06/2014

MARCUSCHI, Luiz Antonio. Da fala para a escrita: atividades de retextualização.10.ed.São Paulo: Cortez, 2010

Parábola, 2009.

Produção textual, Análise de gêneros e compreensão. São Paulo:

MATENCIO, M.L.M. Leitura, produção de textos e a escola: reflexões sobre o processo de letramento. Campinas, SP: Mercado de Letras, 1998.

O Estado de S. Paulo. Manual de redação e estilo. 3. ed. São Paulo: O Estado de São Paulo, 1997.

Disponível:http://naui.ufsc.br/files/2010/09/Manual-de-reda\%C3\%A7\%C3\%A30 -eEstilo_O-Estado-de-S\%C3\%A3o-Paulo.pdf

OLIVEIRA, Mariângela Rios de. Integração de sentido e forma na morfossintaxe do português. In: Palomares,Roza e Bravin, Angela Marina(orgs). P'raticas de Ensino do Português. São Paulo; Contexto, 2012.

PALOMARES, Roza; BRAVIN, Angela Marina(orgs). Práticas de Ensino do Português. São Paulo: Contexto, 2012. 
PERELMAN, Chaïm; OLBRECHTS-TYTECA, Lucie. Tratado da argumentação: a nova retórica.Tradução Maria Ermantina de Almeida Prado Galvão.São Paulo: Martins Fontes, 1996

PIETRI, Émerson de. Práticas de leitura e elementos para a atuação docente.Rio de Janeiro: Ediouro, 2009.

PIMENTEL, Elisabete. Sujeitos leitores, sujeito autores: indícios de histórias de eitura na produção de textos escolares. Disponível em: http://www.bibliotecadigital.unicamp.br/document/?code=vtls000133352\&opt=4

RODRIGUES, Rosângela Hammes . O artigo jornalístico e o ensino da produção escrita. In: ROJO, Roxane (org.). A prática de linguagem em sala de aula. São Paulo: Mercado das Letras, 2000, p. 207-220.

- Os gêneros do discurso na perspectiva dialógica da linguagem: a abordagem de Bakthin. In: Meurer, J. L.; Bonini,Adair; Motta-Roth, Désirée (Orgs.). Gêneros: teorias, métodos, debates. 2 ed. São Paulo: Parábola, 2005, p. 152-183.

ROJO, Roxane (org.). A prática de linguagem em sala de aula. São Paulo: Mercado das Letras, 2000.

. Gêneros dos discurso e gêneros textuais: questões teóricas e aplicadas. In: Meurer, J. L.; Bonini,Adair; Motta-Roth, Désirée (Orgs.). Gêneros: teorias, métodos, debates. 2 ed. São Paulo: Parábola, 2005, p. 184-207.

ROSENBLAT, Ellen. Critérios para a construção de uma sequência didática no ensino dos discursos argumentativos. In: ROJO, Roxane(org.). A prática de linguagem em sala de aula.São Paulo: Mercado das Letras, 2000.

SÃO PAULO. Avaliação da Aprendizagem em Processo 2014. 2. ed. São Paulo: SEE, 2014.

Caderno do Aluno: Língua Portuguesa, Ensino Fundamental, 8 a série/9을 ano, volume 1. Coordenação geral: Maria Inês Fini, coordenação da área: Alice Vieira São Paulo: SEE, 2014.

Caderno do Aluno: Língua Portuguesa, Ensino Fundamental, 8aㅗ série/9o ano, volume 2. Coordenação geral: Maria Inês Fini, coordenação da área: Alice Vieira São Paulo: SEE, 2014. 
Caderno do Professor: Língua Portuguesa, Ensino Fundamental, 8 ${ }^{\text {a }}$ série/9ํㅜ ano, volume 1. Coordenação geral: Maria Inês Fini, coordenação da área: Alice Vieira São Paulo: SEE, 2014

Caderno do Professor: Língua Portuguesa, Ensino Fundamental, 8ª série/9을 ano, volume 2. Coordenação geral: Maria Inês Fini, coordenação da área: Alice Vieira São Paulo: SEE, 2014.

. Currículo do Estado de São Paulo: Linguagens códigos e suas tecnologias. Coordenação geral: Maria Inês Fini, coordenação da área: Alice Vieira São Paulo: SEE, 2012.

Programa de Qualidade da Escola: O que é o IDESP. São Paulo: SEE, 2007. Disponível em http://idesp.edunet.sp.gov.br/

IDESP (2011): Boletim da escola. Disponível em: http://idesp.edunet.sp.gov.br/arquivos2011/012373.pdf. Acesso em 04/02/2014

IDESP (2012): Boletim da escola. Disponível em: http://idesp.edunet.sp.gov.br/arquivos2012/012373.pdf. Acesso em 04/02/2014 . IDESP (2013): Boletim da escola. Disponível em: http://idesp.edunet.sp.gov.br/arquivos2013/012373.pdf. Acesso em 04/02/2014 . Matrizes de Referências para a avalição SARESP. São Paulo: SEE, 2012. Disponível em: http://saresp.fde.sp.gov.br/2012/Arquivos/Saresp2012_MatrizRefAvaliacao_DocBasi co_Completo.pdf

SCHIAVONi, Andreza. Proposta de uma intervenção educativa baseada em estratégias para a produção de textos. Disponível em: http://www.bibliotecadigital.unicamp.br/document/?code=000477869\&opt=4

SCHNEUWLY, Bernard ; DOLZ, Joaquim e colaboradores. Gêneros Orais e Escritos na Escola. Tradução e organização de Roxane Rojo e Glaís Sales Cordeiro. 3 ed. Campinas: Mercado de Letras, 2013

SILVA, Leila Nascimento; LEAL, Telma Ferraz. Caracterizando o gênero carta de reclamação. In: CONGRESSO DE LEITURA DO BRASIL, 16., 2007, Campinas. 
Anais... Campinas: ALB/UNICAMP, 2007. Disponível em: <www.alb.com.br/anais16/sem10pdf/sm10ss12_07.pdf>. Acesso em: 30 jun. 2014

SOARES, Magda. Linguagem e escola: uma perspectivia social. São Paulo: Ática, 1995.

SOARES, Magda. ALFABETIZAÇÃO E LETRAMENTO: CAMINHOS E DESCAMINHOS. Revista Pátio, n.29, fev/2004

TARALLO, Fernando. A pesquisa socio-linguística.São Paulo: Ática, 1990

WACHOWICZ, Teresa Cristina. Análise linguística nos gêneros textuais. São Paulo: Saraiva, 2012.

ZABALA, Antoni. A prática educativa: como ensinar; tradução Ernani F. da F. Rosa. Porto Alegre: Artmed, 1998. 


\section{ANEXOS}

\section{ANEXO A}

Nome completo:

Data de nascimento

Endereço:

Bairro:

CEP:

Cidade

UF:

Telefone:

01) Quantos membros da sua família moram com você?

( ) 1 ( ) 2 ( ) 3 ( ) 4 ( ) 5 ( ) mais de 5

06) Quadro Familiar

Abaixo deverão ser lançados dados sobre sua família de origem. VOCÊ INCLUSIVE.

\begin{tabular}{|l|l|l|l|l|l|}
\hline $\begin{array}{l}\text { Membro da } \\
\text { família }\end{array}$ & Idade & Escolaridade & Parentesco & Profissão & $\begin{array}{l}\text { Renda } \\
\text { Mensal } \\
\text { (Valor } \\
\text { Bruto) }\end{array}$ \\
\hline & & & & & \\
\hline & & & & & \\
\hline & & & & & \\
\hline & & & & & \\
\hline
\end{tabular}

02) Você ou algum membro de sua família são beneficiários de Programas Sociais (Bolsa Família, Benefício de Assistência Social, etc.)?
( ) Sim. Qual? Valor R \$:
( ) Não.

03) Você e sua família residem? ( ) Zona Urbana ( ) Zona Rural

04) Você e sua família residem? ( ) Imóvel próprio ( )Imóvel Alugado

05) Marque as características que melhor descrevem a sua casa . Pode marcar mais de uma opção.

( ) Residência com acabamento.

( ) Residência sem acabamento (sem reboco, pintura, piso, banheiros inacabados, etc.)

Possui: ( ) Rede de Esgoto ( ) Fossa ( ) Banheiro ( ) Chuveiro ( ) Água ( ) Luz

Cobertura: ( ) Laje ( ) Telha () Outros.

Piso: ( ) Cimento ( ) Taco ( ) Cerâmica ( ) Outros.

Número de Cômodos:

06) Você trabalha atualmente?

Sim ( ) Onde?

Não ( )

07) Qual atividade você desenvolve em seu dia a dia, fora da escola? 
08) Quais suas habilidades e quais as atividades que você gosta de desenvolver?

09 )No seu domicílio há (quantos?):
( ) Aparelho de Som?
( ) Televisão?
( ) DVD?
( ) Geladeira?
( ) Freezer independente?
( ) Máquina de lavar roupa?
( ) Computador (micro, laptop ou notebook)?
( ) Telefone fixo?
( ) Telefone celular?
( ) TV por assinatura?
( ) Automóvel?
( ) Motocicleta?
( ) Livros(sem contar os da escola)
( ) Revistas
( ) Bíblia

10 )Você e/ou sua família tem convênio com plano de saúde (médico ou odontológico)?

( ) $\mathrm{Sim}$

( ) Não

11) Com que freqüência você tem acesso a estes meios de informação?

\begin{tabular}{|l|l|l|l|l|l|}
\hline & Diariamente & $\begin{array}{c}\text { Quase } \\
\text { diariamente }\end{array}$ & Às vezes & Raramente & Nunca \\
\hline Jornais & & & & & \\
\hline Revistas & & & & & \\
\hline Televisão & & & & & \\
\hline Internet & & & & & \\
\hline Livros & & & & & \\
\hline $\begin{array}{l}\text { Rádio } \\
\text { AM/FM }\end{array}$ & & & & & \\
\hline
\end{tabular}

12) Quantos livros em média você costuma ler por ano?
( ) Nenhum
( ) De 11 a 15 livros
( ) Um livro
( ) De 16 a 20 livros
( ) De 2 a 5 livros
( ) De 21 a 30 livros
( ) De 6 a 10 livros
( ) Mais do que 30 livros 


\section{ANEXO B}

\section{Texto 1}

Com base nos textos de apoio, nas pesquisas realizadas em sala e na sala de informática, nos seus conhecimentos sobre o assunto, escreva um artigo de opinião sobre o seguinte tema:

O que o evento da Copa deixará para o Brasil, depois da Copa?

Observações

Não deve estar redigido sob a forma de poema (versos) ou narração;

A redação deve ter no mínimo 15 e no máximo 30 linhas escritas;

Não deixe de dar um título à sua redação.

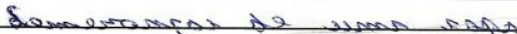

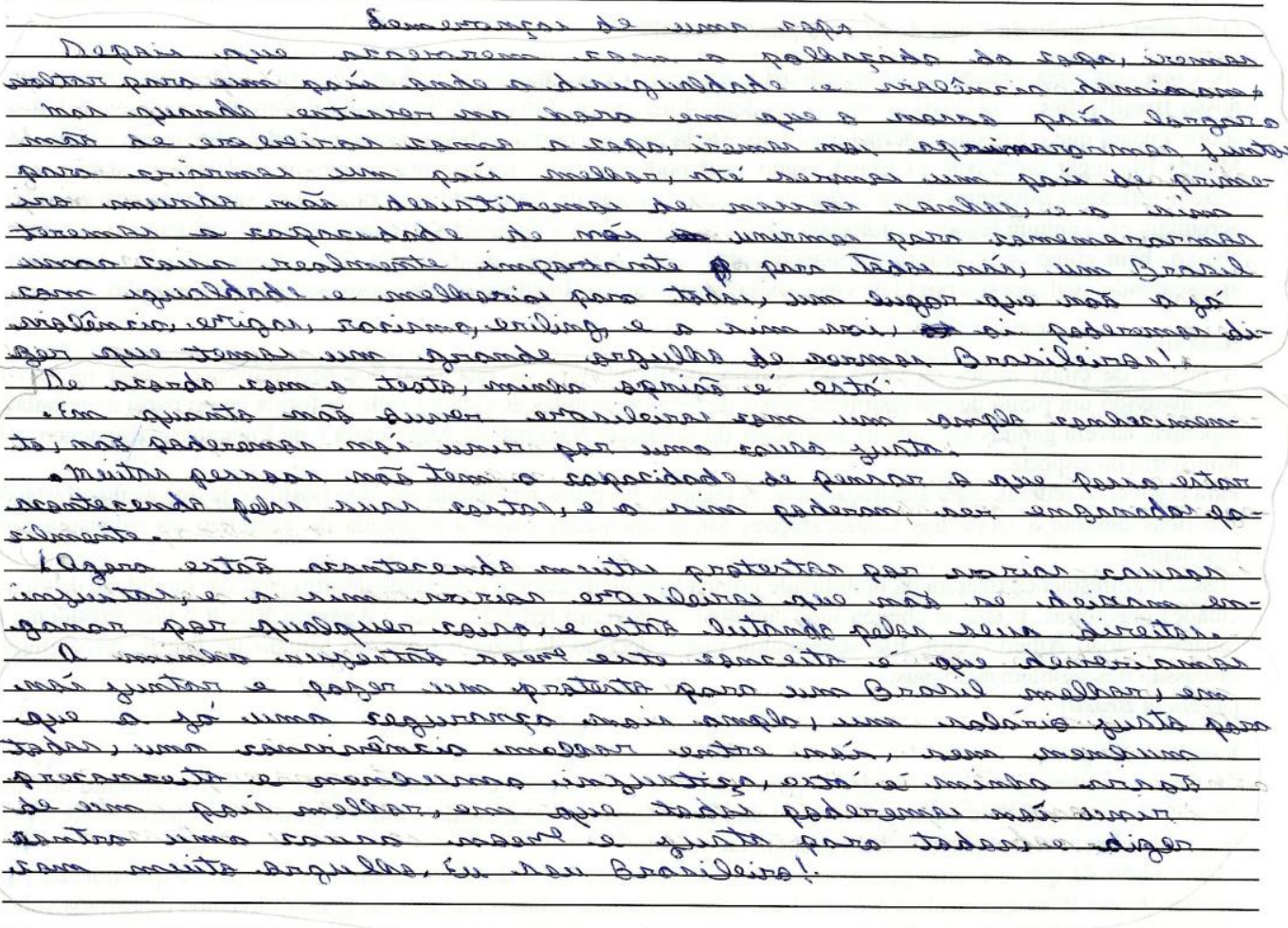


Texto 2

Com base nos textos de apoio, nas pesquisas realizadas em sala e na sala de informática, nos seus conhecimentos sobre o assunto, escreva um artigo de opinião sobre o seguinte tema:

O que o evento da Copa deixará para o Brasil, depois da Copa?

Observações

Não deve estar redigido sob a forma de poema (versos) ou narração;

A redação deve ter no mínimo 15 e no máximo 30 linhas escritas;

Não deixe de dar um título à sua redação.

Brasil um paiz paro toodos'fexor" bagunga

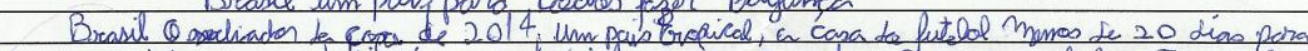

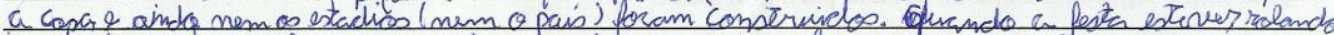

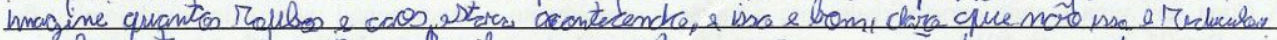

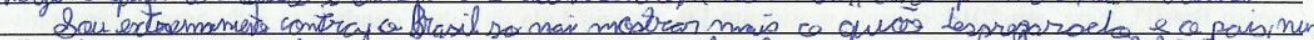

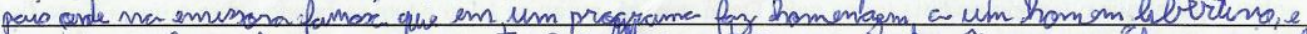

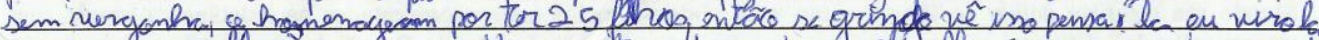

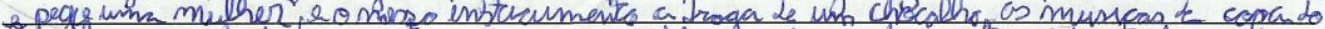

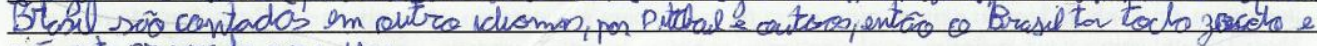
póce este preparado poica isso.

Dor que sou contrawi

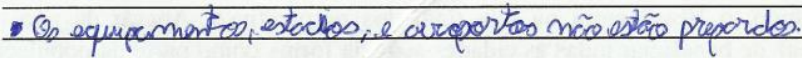

- Oeleicemportes

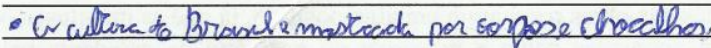

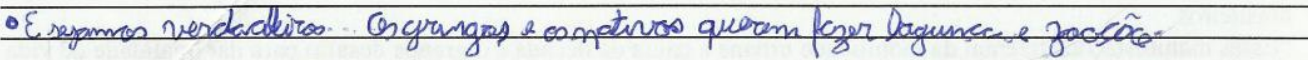

- E falta constraur a paí

(6)

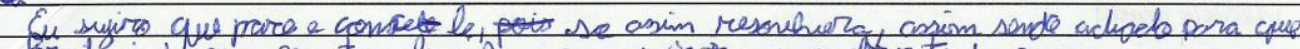

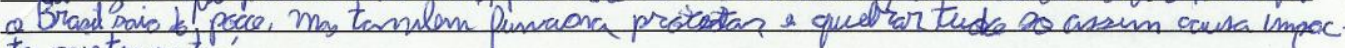
tc. pes trammotioí

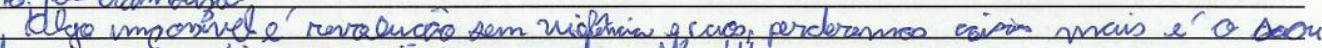
firio, nora um disim pais, um munda mellor!!! 


\section{Texto 3}

Com base nos textos de apoio, nas pesquisas realizadas em sala e na sala de informática, nos seus conhecimentos sobre o assunto, escreva um artigo de opinião sobre o seguinte tema:

O que o evento da Copa deixará para o Brasil, depois da Copa?

\section{Observações}

Não deve estar redigido sob a forma de poema (versos) ou narração;

A redação deve ter no mínimo 15 e no máximo 30 linhas escritas;

Não deixe de dar um título à sua redação.

$$
\text { Fila } 2014
$$

Fu acho que a caper no Braul estä senido leval acho bacana rem dorro gastaram muito denhevio main de 20 milhon em estadion avraportonete..., Sendo quee les podiom investir em escolan, saivder.

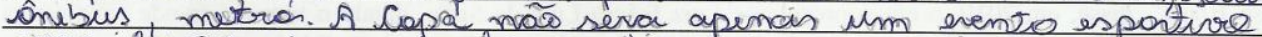
mas laro será um rvento espentivo, te uma opertunidade do Brasa mantrar av mundeb, mortra forca la vitalidadle da necão

Zu concordo cam o Brasil

- I copa sera uma grande opontuni dade para acelerar o crescime. nto e fundamental para o desenvohimento do nosso Brasil

- Cucho ridiculo essas manilestacôs que as pessoas estaü lazenas Pra que isso aqura pa i tarde pa gastaram o dinheiro não tem como voltar main atrain, vai guebras as coisas atoua porque elen voro arou mar con o mosso di theirs "di nhoiro do en pootso"

- Alqumas pessoas braibleran tem que entender que o Bravil vai ganhar.

Deve ser fieto uma manifestacáo dixito pa que querem fazer

so- nāo destruindo main nada. Mair Jenho certe za que eles gastanam esse dinheirã̃o ponque vai voler apena ponque tenero centeza do Brasil vai ganhar.

\section{Texto 4}

Com base nos textos de apoio, nas pesquisas realizadas em sala e na sala de informática, nos seus conhecimentos sobre o assunto, escreva um artigo de opinião sobre o seguinte tema:

O que o evento da Copa deixará para o Brasil, depois da Copa?

\section{Observações}

Não deve estar redigido sob a forma de poema (versos) ou narração;

A redação deve ter no mínimo 15 e no máximo 30 linhas escritas;

Não deixe de dar um título à sua redação.

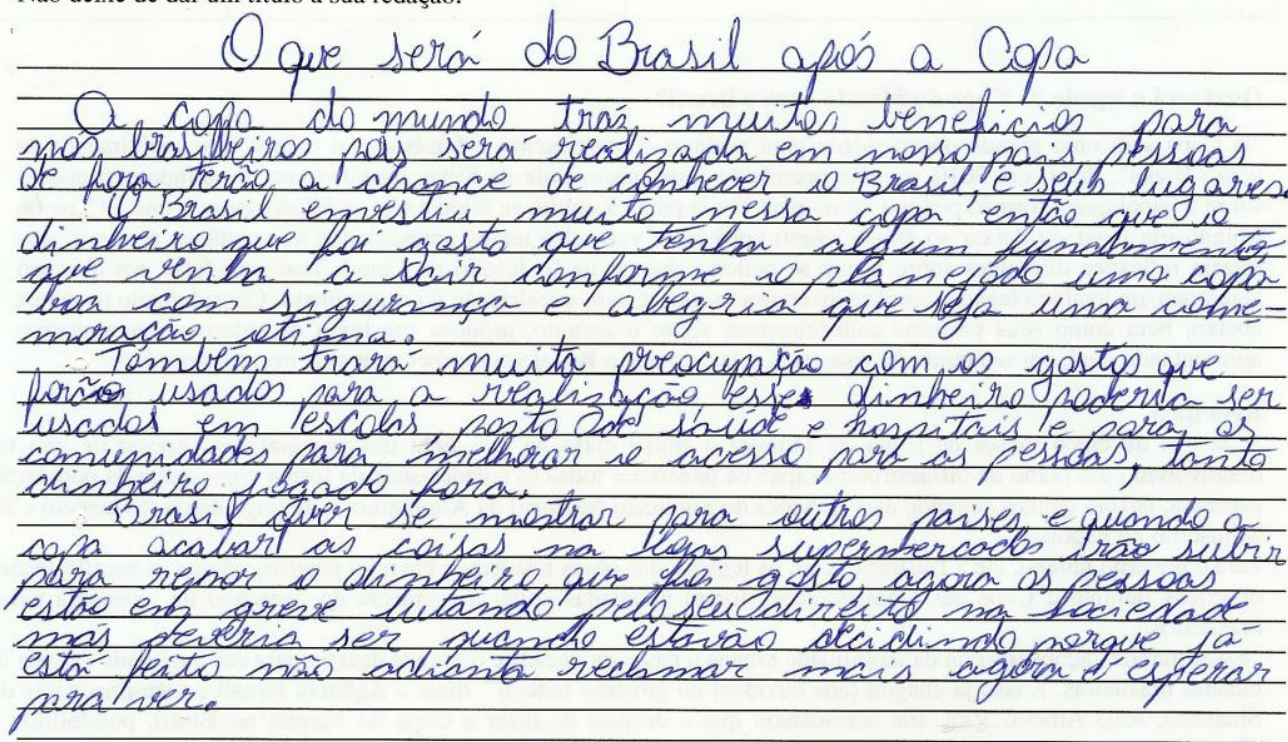




\section{Texto 5}

Com base nos textos de apoio, nas pesquisas realizadas em sala e na sala de informática, nos seus conhecimentos sobre $o$ assunto, escreva um artigo de opinião sobre o seguinte tema:

O que o evento da Copa deixará para o Brasil, depois da Copa?

\section{Observações}

Não deve estar redigido sob a forma de poema (versos) ou narração;

A redação deve ter no mínimo 15 e no máximo 30 linhas escritas;

Não deixe de dar um título à sua redação.

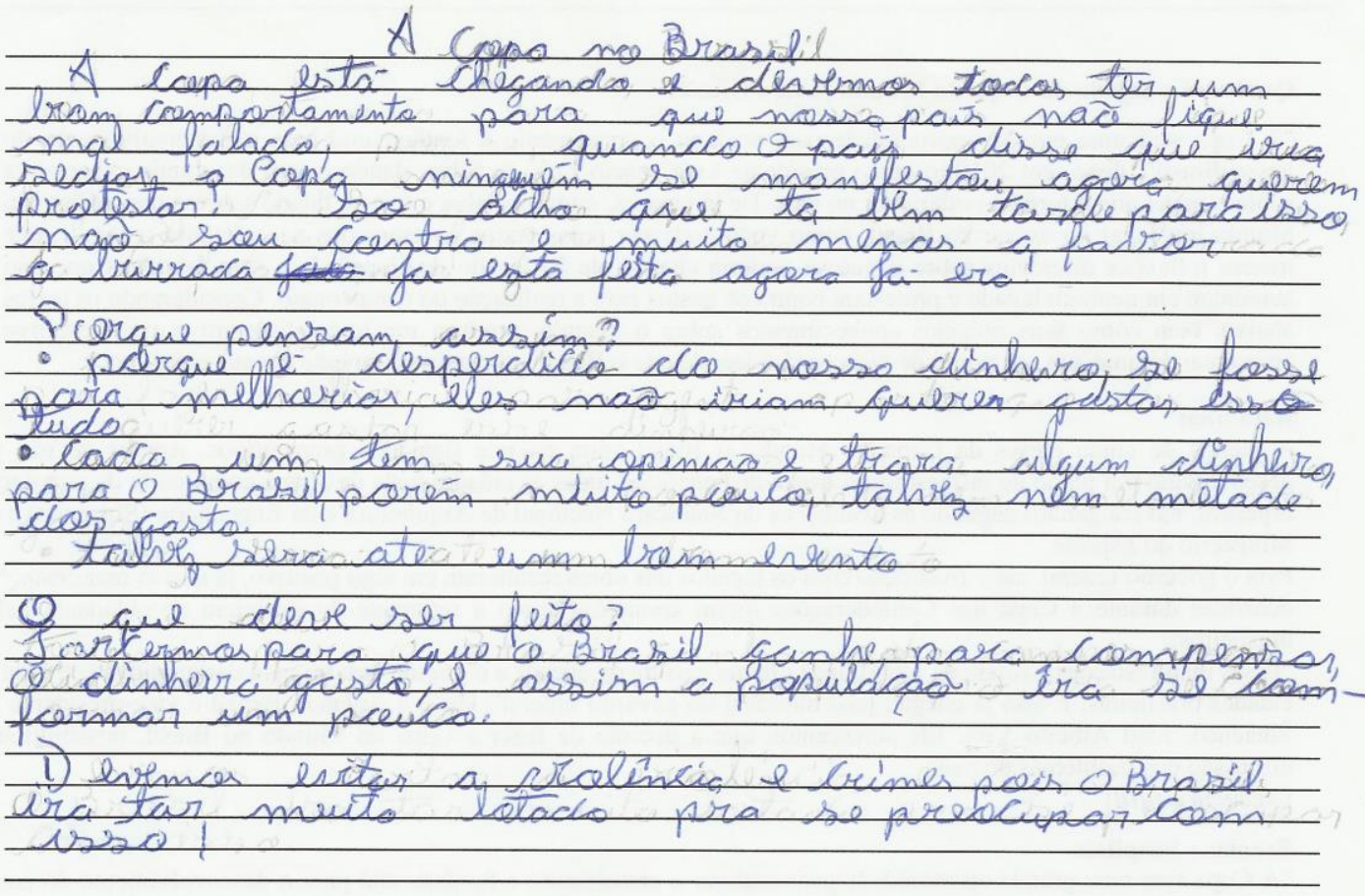




\section{ANEXO C}

\section{Texto 1}

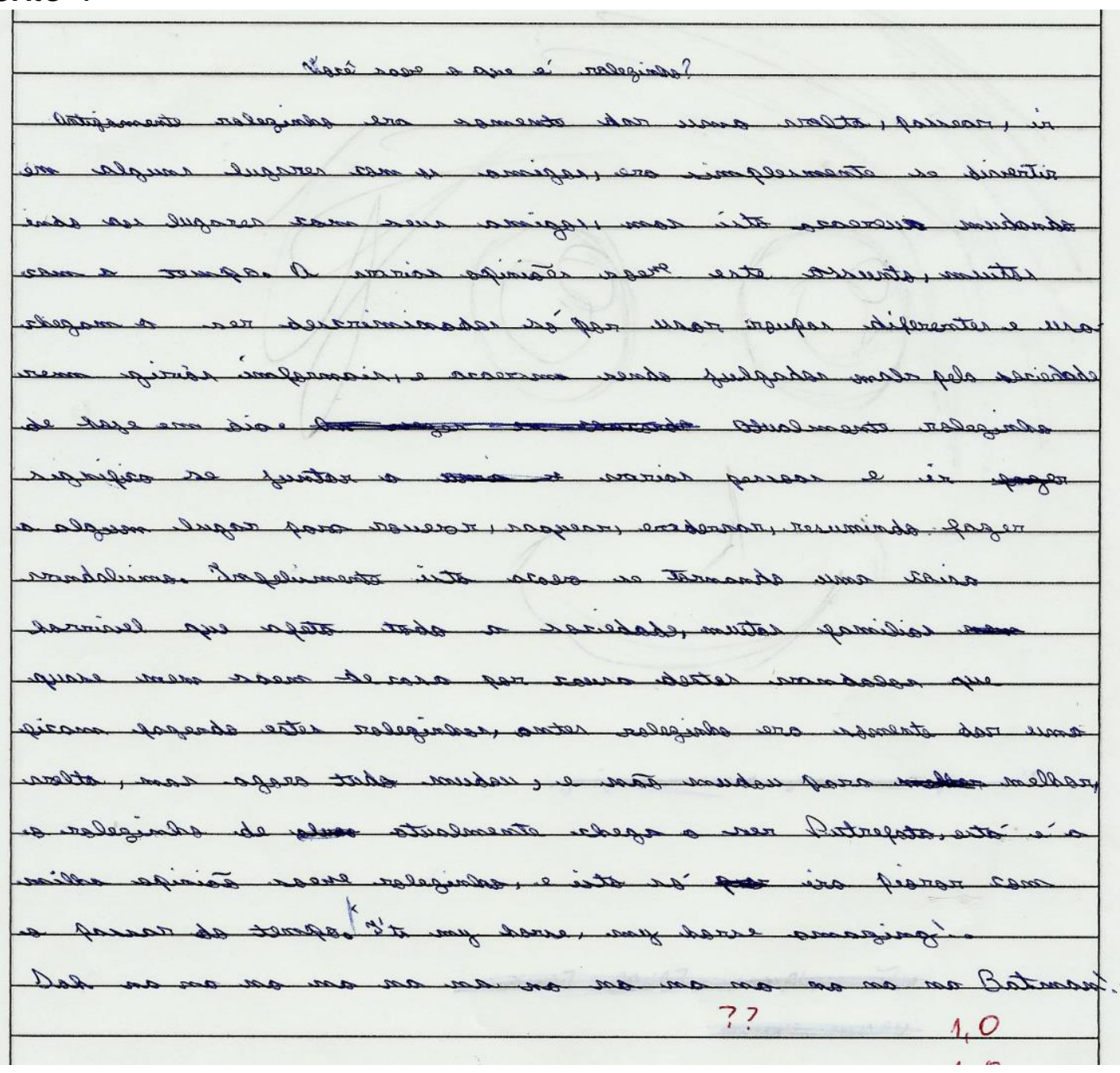


Texto 2

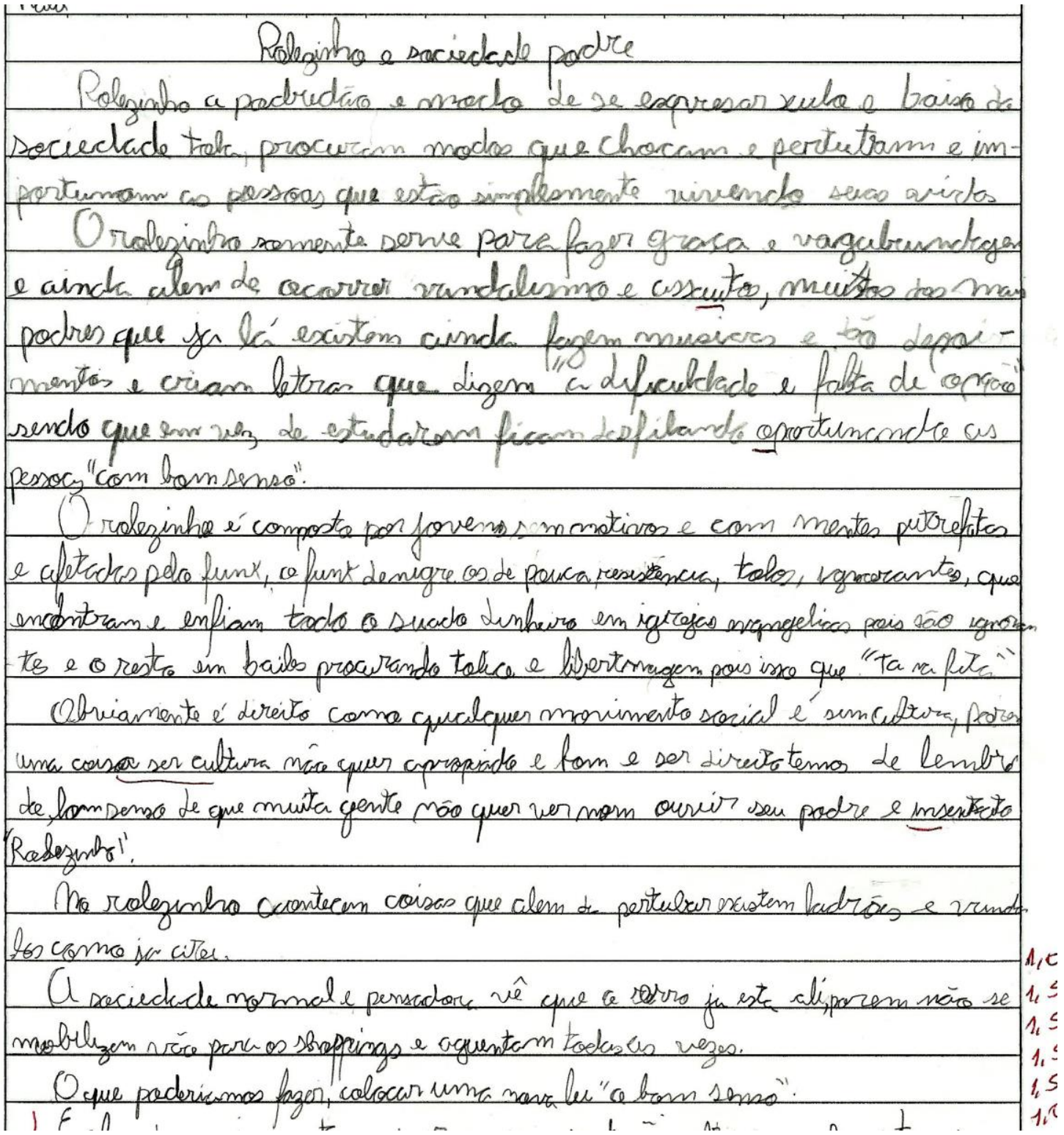




\section{Texto 3}

Rolé de hape em dia

Haye em dia a rolezinho é um "bonde" de pessoas

adobcentes que saiam para se divert ir ou dar um role-, eles váo muito na pracas, no shopping, no calcadaó baxzinho, fasem isse greupo esse "bonde" de adolecentes para par o papo em dia, beler um pouco dar uma volta, parque aliain todes sã linte para sair cada um tem sen dirito.

Existe relezinho o'bonde "dos adolecentes para eles sair e se divertir, nâo quer dizer que eles são liveres para. faser oquér. sim claro sâo lives, mair existemlier, porque tem uns bondes de adolecentes gue gasta de montar um grupo para ir no shopping para roiblar, bater nas pessoas, estragar algo. E'isso não esta certo cada um tem que ter seu limite e respeitar a todos.

No rolezinho dos adolecent es e um grupo com main de 5 persoas ou main não da para saber isso pode ser pauco o bastante depende de cada greupe, isso s a penas uma fase da vida isso tudo passa é direito de cada un ser twie main sabendo ser sem aprontar paque pode prefudicar a si mesmo.

Tem varier tipas de pesseas num rolezinho, os main Top's, as emos, os rockeiros, os statestas, funkunos... codo un tuntiando se divortir Ique a soriedade pen sa eu não sei par que cada um Iem sua opinião, a minha deixcar eles ser feliz mais sem presudicar niquem, podia mudar al gumas coiras parcas coisar, por què acho que iria melhonar um parco mair ia servir pra quem nã sesperta. 
161

Texto 4

(1) que é rolyzinho

Rolezinho e' uma naraforma que is fovens eusam para chefinir: dar unia velta, ir re divertid. Sair com as carnigos, em geral

a maigria que sai de rolezintho são forens e adobescentes, por que para eles está na moda o termo rolezinho, por que é atual na lingyagem dos fovens.

. rolezinho é um direito

por que nós, seres humanos somas liveres ara sair, passear, se divertir, mas temos que ter respeitos nas beis do local em gue se encentra.

Na minha cidade se encontrar algumas persoas que usam essa palovera, tem lugares em que se encontro essas pesseas geralmente essas pessoas se encentram em latodas, lugores ence muitas pessoas frequentar, luganes molis pisulares. essar palavias existe por alguns Mo ultilizam essa palavio em suas musicas, por isso essa palavor é popular na loca das persoas que curtem esses tipas de musicas como i, ¿ ai? Como garantir o ducito? $i, k$

1,2

1,1 


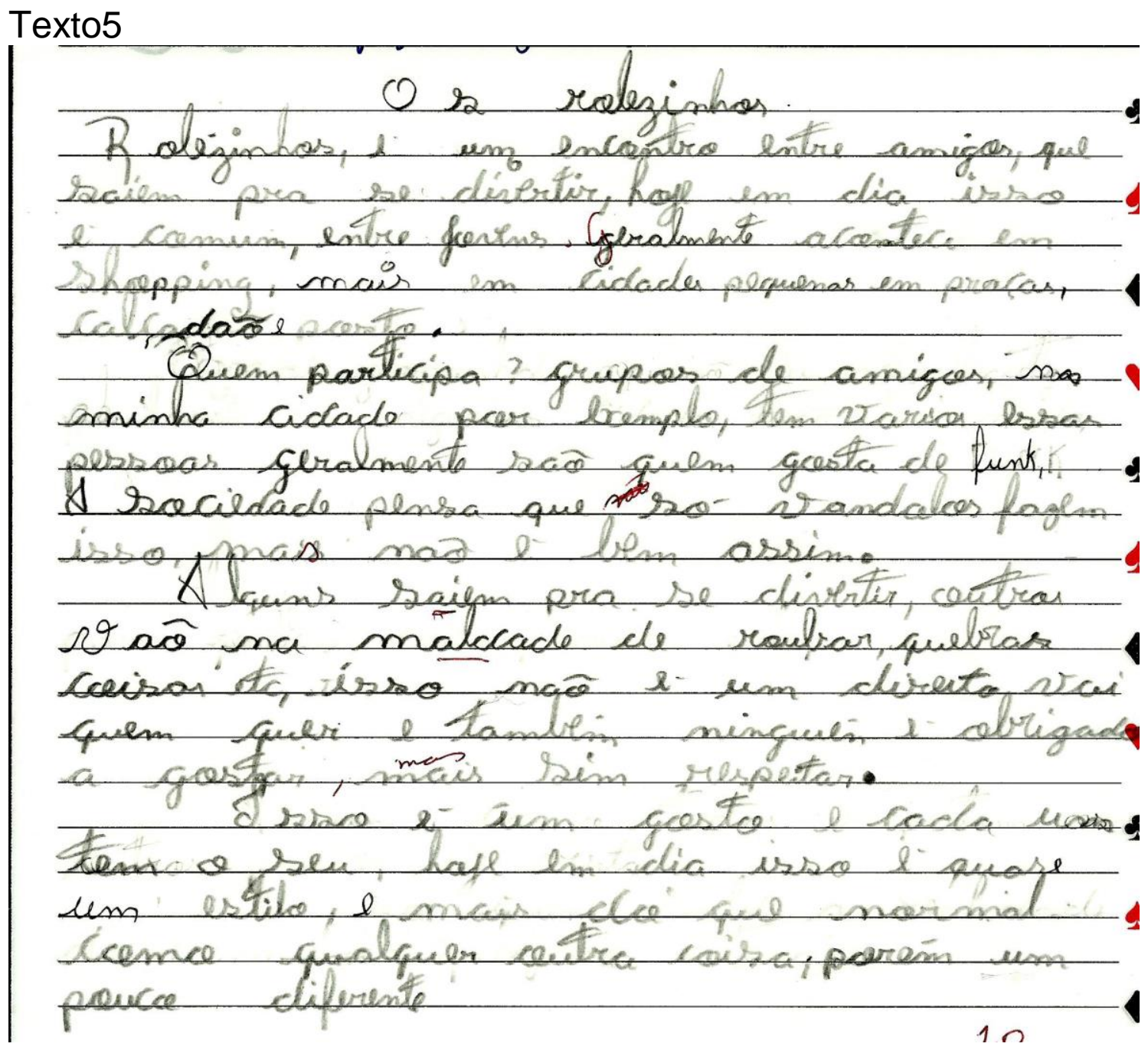

\section{ANEXO D}

\section{Atividade 1}

Coloque a vírgula nessa frase:

SE O HOMEM SOUBESSE O VALOR QUE TEM A MULHER ANDARIA DE QUATRO À SUA PROCURA.

Após um tempo, compartilhamos o resultado. Somente um aluno colocou a vírgula em um lugar impróprio (depois do segundo artigo $o$ ). Os demais se dividiram entre depois da palavra tem ou depois da palavra mulher. Como havíamos trabalhado recentemente um artigo de opinião sobre o papel da mulher na sociedade, fiz uma brincadeira com o resultado.

Se você colocou a vírgula depois da palavra tem: você é machista.

Se você colocou a vírgula depois da palavra mulher: você é inteligente. 
Houve uma boa receptividade e no momento de refletirmos sobre as escolhas feitas, aquele aluno que não pontuou adequadamente compreendeu o motivo de não se separar determinante da palavra determinada.

\section{Atividade 2}

O texto abaixo foi colocado em partes no quadro. A cada par de palavra fazia uma pausa e pedia para que eles ora pontuasse com a intenção sugerida, ora dava a pontuação e questionava-os sobre as diferenças de sentido entre as construções.

\section{O VALOR DA VÍRGULA}

Muito legal a campanha dos 100 anos da ABI (Associação Brasileira de Imprensa). http://www.youtube.com/watch?v=uWKpx5Ls1zg

Vírgula pode ser uma pausa... ou não.

Não, espere.

Não espere.

Ela pode sumir com seu dinheiro.

23,4 .

2,34 .

Pode ser autoritária.

Aceito, obrigada.

Aceito obrigada.

Pode criar heróis.

Isso só, ele resolve.

Isso só ele resolve.

E vilões.

Esse, juiz, é corrupto.

Esse juiz é corrupto.

Ela pode ser a solução.

Vamos perder, nada foi resolvido.

Vamos perder nada, foi resolvido.

A vírgula muda uma opinião.

Não queremos saber.

Não, queremos saber.

Uma vírgula muda tudo.

Fonte: www.correiodeuberlandia.com.br/revisaonanet/2011/.../o-valor-da-virgu.

Após a reflexão dessa atividade, sugeri a seguinte proposta:

- A herança 
Um homem rico estando muito mal de saúde, pediu que lhe trouxessem papel e tinta.

Escreveu o seguinte:

Deixo meus bens à minha irmã não a meu sobrinho jamais será paga a conta do padeiro nada dou aos pobres.

Deu o último suspiro antes de ter podido fazer a pontuação. A quem, afinal, deixava sua fortuna?

Eram apenas quatro os citados.

No dia seguinte, ao receberem o papel, cada um dos citados deu ao texto a pontuação e a interpretação que lhe favorecia.

(Autor desconhecido)

Reescreva o texto pontuando da mesma forma que eles.

O sobrinho fez a seguinte pontuação:

A irmã chegou em seguida e o pontuou assim:

O padeiro pediu cópia do original e o deixou dessa forma:

A notícia se espalhou pelas redondezas e um sabido homem representando os pobres deixou o texto desse jeito: 